\title{
Examination of Zircaloy-Clad Spent Fuel After Extended Pool Storage
}

September 1981

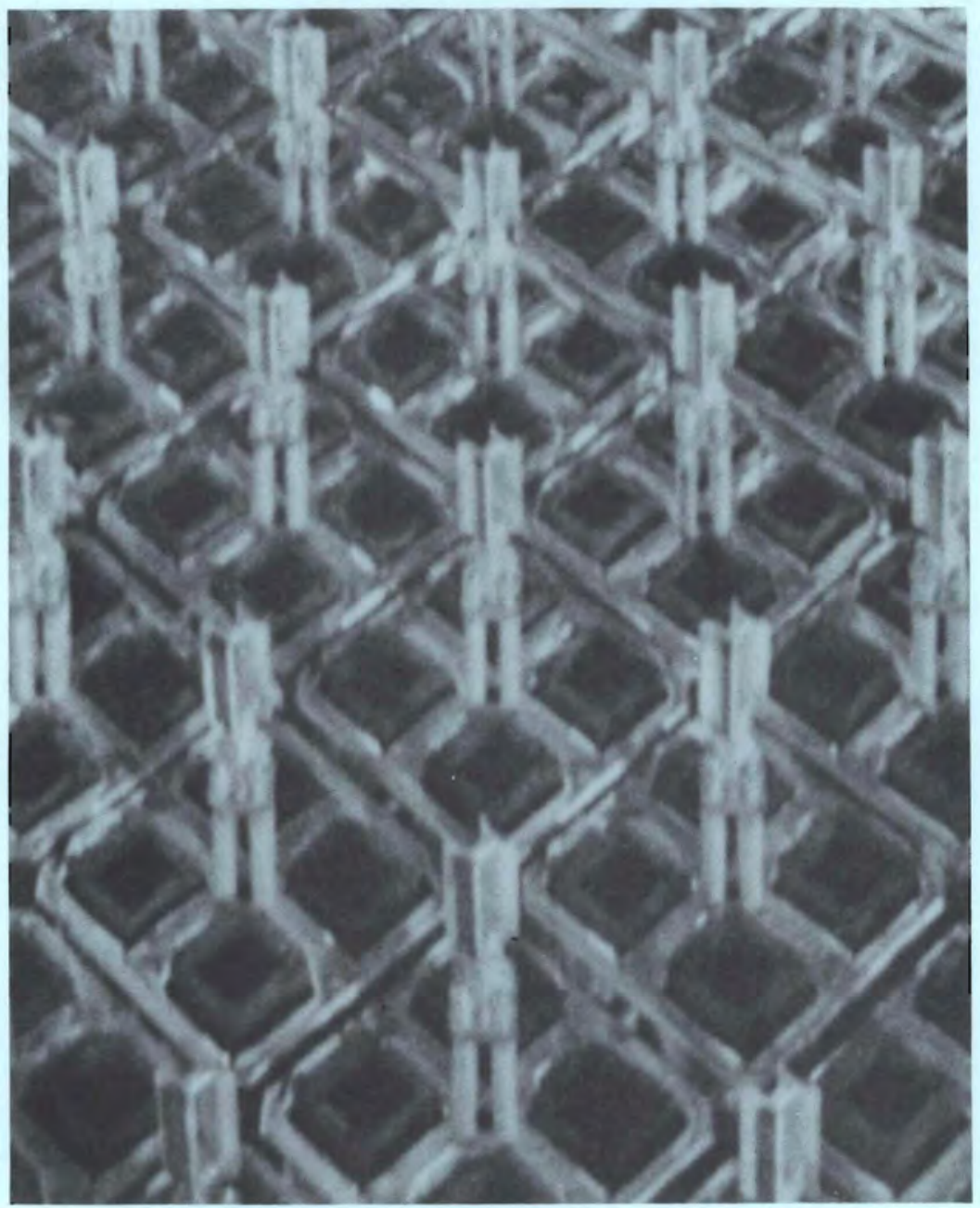

Prepared for the U.S. Department of Energy under Contract DE-AC06-76RLO 1830

Pacific Northwest Laboratory Operated for the U.S. Department of Energy by Battelle Memorial Institute 
This report was prepared as an account of work sponsored by the United States Government. Neither the United States nor the Department of Energy, nor any of their employees, nor any of their contractors, subcontractors, or their employees, makes any warranty, express or implied, or assumes any legal liability or responsibility for the accuracy. completeness or usefulness of any information, apparatus. product or process disclosed, or represents that its use would not infringe privately owned rights.

The views, opinions and conclusions contained in this report are those of the contractor and do not necessarily represent those of the United States Government or the United States Department of Energy.

\section{PACIFIC NORTHWEST LABORATORY}

operated by

BATTELLE

for the

UNITED STATES DEPARTMENT OF ENERGY

Under Contract DE-AC06-76RLO 1830

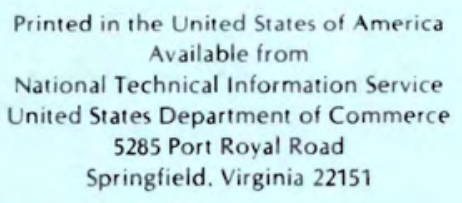

Price: Printed Copy \$ $\because$ Microfiche $\$ 3.00$

$\begin{array}{lr}\text { •Pages } & \begin{array}{c}\text { NTIS } \\ \text { Selling Price }\end{array} \\ 001-025 & \$ 4.00 \\ 026-050 & \$ 4.50 \\ 051-075 & \$ 5.25 \\ 076-100 & \$ 6.00 \\ 101-125 & \$ 6.50 \\ 126-150 & \$ 7.25 \\ 151-175 & \$ 8.00 \\ 176-200 & \$ 9.00 \\ 201-225 & \$ 9.25 \\ 226-250 & \$ 9.50 \\ 251-275 & \$ 10.75 \\ 276-300 & \$ 11.00\end{array}$


E. R. Bradley

W. J. Bailey

A. B. Johnson, Jr.

L. M. Lowry a

September 1981

Prepared for the U.S. Department of Energy under Contract DE-AC06-76RLO 1830

Pacific Northwest Laboratory

Richland, WA 99352

(a) Battelle-Columbus Laboratories, Columbus, Ohio. 

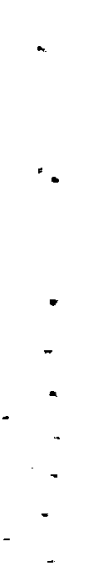


\section{ACKNOWLEDGMENTS}

The help of the following people in support of the Spent Fuel and Fuel Pool Component Integrity Program, which is sponsored at Pacific Northwest Laboratory (PNL) by the U.S. Department of Energy under Contract DE-AC06-76RLO 1830, is acknowledged:

- W. M. Cella, G. G. Weddell, and R. Atherton of Bettis Atomic Power Laboratory for arranging transfer of the Shippingport fuel from the Naval Reactors Program to this program and in providing background information on the fuel

- R. W. Klingensmith and V. Pasupathi of Battelle Columbus Laboratories (West Jefferson site) for hot cell examination

- W. H. Baker of the Savannah River Plant for guidance and participation in program planning and implementation

- D. E. Blahnik of PNL for arranging shipment of the Shippingport fuel

- S. K. Edler of PNL for editing and coordinating this report. 


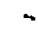

$\ddots$ 
SUMMARY

The current moratorium for reprocessing nuclear fuels in the United States has left extended water storage as the only licensed fuel management option for commercial spent fuel. Past experience and assessments of pool-stored spent fuel suggest that no significant degradation of the fuel rod cladding occurs during water storage. However, at present the experimental data base is 1 imited; and additional investigation is needed to assess whether degradation of Zircaloy fuel cladding occurs during extended water storage.

This report presents the results from metallurgical examinations of Zircaloy-clad fuel rods from two bundles (0551 and 0074) of Shippingport PWR Core 1 blanket fuel after extended water storage. Both bundles were exposed to water in the reactor from late 1957 until discharge. The estimated average burnups were $346 \mathrm{GJ} / \mathrm{kgU}$ ( $4000 \mathrm{MWd} / \mathrm{MTU}$ ) for bundle 0551 and $1550 \mathrm{GJ} / \mathrm{kgU}$ (18,000 MWd/MTU) for bundle 0074. Fuel rods from bundle 0551 were stored in deionized water for nearly $21 \mathrm{yr}$ prior to examination in 1980, representing the world's oldest pool-stored Zircaloy-clad fuel. Bundle 0074 has been stored in deionized water since reactor discharge in 1964 . Data from the current metallurgical examinations enable a direct assessment of extended pool storage effects because the metallurgical condition of similar fuel rods was investigated and documented soon after reactor discharge.

Data from current and past examinations were compared, and no significant degradation of the Zircaloy cladding was indicated after almost $21 \mathrm{yr}$ in water storage. The cladding dimensions and mechanical properties, fission gas release, hydrogen contents of the cladding, and external oxide film thicknesses that were measured during the current examinations were all within the range of measurements made on fuel bundles soon after reactor discharge. The appearance of the external surfaces and the microstructures of the fuel and cladding were also similar to those reported previously. In addition, no evidence of accelerated corrosion or hydride redistribution in the cladding was observed.

The only microstructural features observed during the current examinations that had not been previously identified and reported were a few microcrack-like defects ( $50 \mu \mathrm{m}$ deep) on the internal surfaces of one fuel rod from bundle 0074. 
These defects are believed to have been formed during fabrication of the cladding; however, they could possibly be shallow stress corrosion cracks produced during irradiation. The formation or propagation of these small microcracks is not considered likely during water storage because of the minimal stresses at internal surfaces and the low temperatures that restrict fission product mobility and crack propagation.

The fact that no significant cladding degradation occurred after nearly $21 \mathrm{yr}$ of pool storage indicates that successful storage of Zircaloy-clad fuel in water for several decades in an excellent prospect. This conclusion agrees with results of spent fuel examinations in Canada, the Federal Republic of Germany, and the United Kingdom. The survival of Shippingport fuel, which remained in the reactor from 1957 to 1974 (12.3 yr at reactor operating conditions; 41,000 MWd/MTU burnup), is another impressive demonstration that Zircaloy-clad fuel has excellent resistance to degradation by water. 
ACKNOWLEDGMENTS

SUMMARY

INTRODUCTION

BACKGROUND INFORMATION

FUEL SELECTION

REACTOR OPERATION AND FUEL CHARACTERISTICS

POOL STORAGE CONDITIONS

FUEL SHIPMENT •

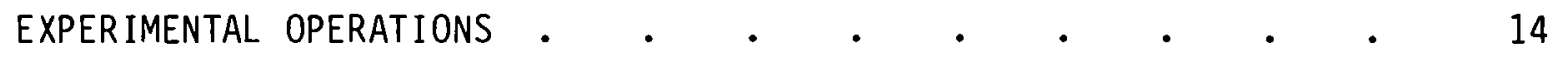

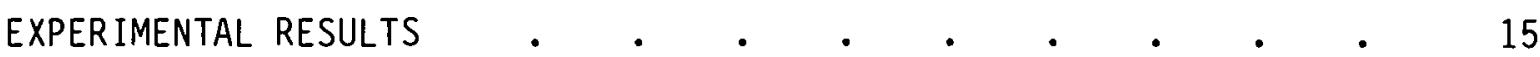

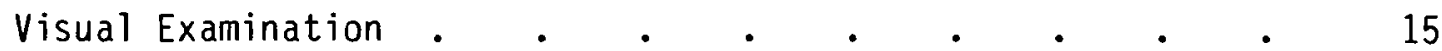

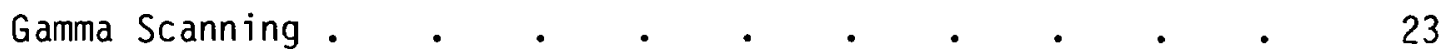

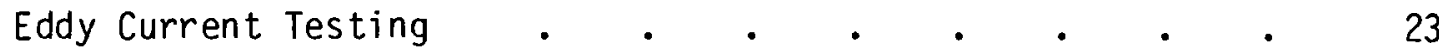

Profilometry . . . . . . . . . . . . 24

Leak Testing and Fission Gas Release . $\quad$ • . . 24

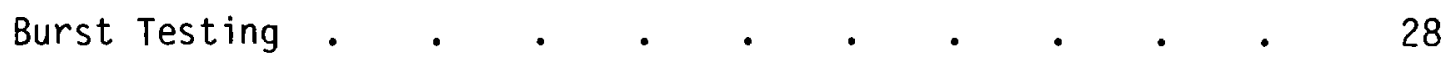

Metallography and Hydrogen Analysis $\quad$ • $\quad$ • $\quad$ • 32

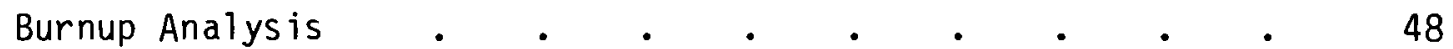

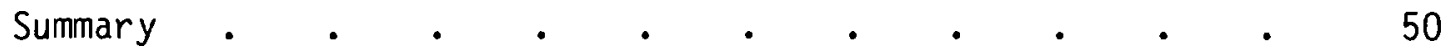

DISCUSSION

COMPARISON WITH PREVIOUS SHIPPINGPORT EXAMINATIONS $\quad$ • $\quad$ • $\quad 51$

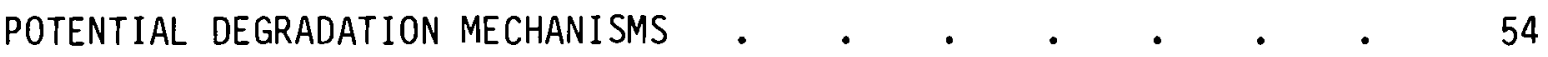

RELATION TO PREVIOUS EXAMINATIONS OF POOL-STORED SPENT FUELS • • 56 


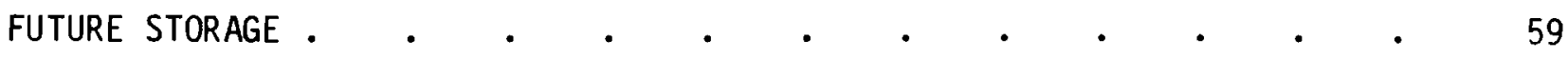

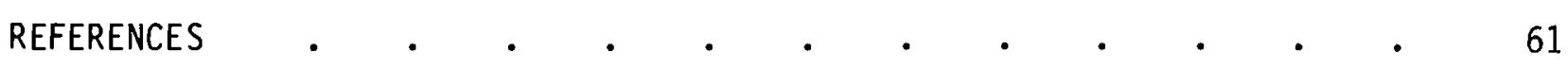

APPENDIX A - EXPERIMENTAL PROCEDURES AND IDENTIFICATIONS • • • • A A.1 


\section{FIGURES}

1 Schematic of Shippingport PWR Core 1 Cross Section $\quad$ - $\quad$ - 6

2 Shippingport PWR Blanket Fuel Rod .

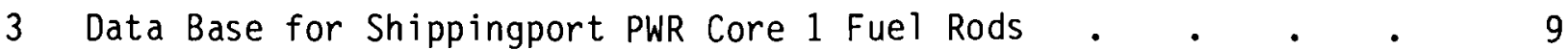

4 Plan View of PWR Core 1 Blanket Fuel Bundle with Rod

Numbering Scheme $. \quad . \quad . \quad . \quad . \quad . \quad . \quad$.

5 General Appearance of Zircaloy-Clad Fuel Rods in Two Shippingport Fuel Bundles After Extended Water Storage . . . . .

6 Typical Crud or Water Spots and Scratches on Fuel Rods from Bundle 0551

7 Appearance of Tube Sheet Surfaces on Shippingport Fuel Bundle 0551; Cut in 1960 and Exposed to the Water Environment for $\sim 21 \mathrm{yr}$

8 Gray Oxide Spots on Rod 112 of Bundle $0074 \quad \ldots \quad$. $\quad$. $\quad$ e 21

9 Superficial Defect on Rod 110 of Bundle 0074 . $\quad$. $\quad$ e $\quad$ e $\quad 21$

10 Crack-Like Surface Marking on Rod 5 of Bundle 0551 . $\quad$ • 22

11 Shippingport Fuel Rods 119 and 4 After Burst Testing . . . 30

12 Cutting Diagram for Shippingport Fuel Rods . . . . . . 33

13 Cutting Diagram for 3-mm Thick Slice from the Bottom End of Rod 110 of Bundle $0074 \quad$. $\quad . \quad$. . . . . . . 33

14 Typical Oxide Films on External Cladding Surfaces After Extended Water Storage $. \quad . \quad . \quad . \quad . \quad . \quad . \quad . \quad . \quad$.

15 Transverse Section Showing Superficial Defect on the External Surface of Rod 110 of Bundle 0074 .

16 Fuel-to-Cladding Bonding in Rod 120 of Bundle $0074 \quad$. $\quad$. $\quad 39$

17 Cladding Imperfections on the Internal Surfaces of Shippingport

PWR Core 1 Fuel Rods . . . . . . . . . . .

18 Microcrack on Internal Surface of Rod 120 of Bundle 0074

that Could Have Been Produced During Cladding Fabrication or by Stress Corrosion Cracking During Reactor Operation . 
19 Typical Hydride Distributions in Shippingport PWR Core 1 Fuel Rod Cladding After Extended Water Storage . . . . .

20 Contact Area Between the Steel Lifting Cable and the Bottom End of Rod 110 of Bundle 0074 . . . . . . . . . .

21 End Cap Welds from Shippingport Fuel Rods After Extended Water Storage

22 Typical Microstructures of Shippingport Fuel After Extended

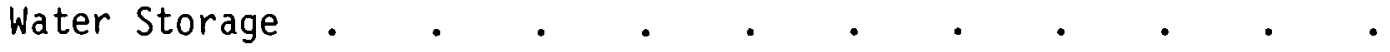

23 Summary of Spent Fuel Examinations to Define Effects of Water Storage.$\quad \cdot \quad \cdot \quad \cdot \quad \cdot \quad \cdot \quad \cdot$.

A.1 Plan View of PWR Core 1 Blanket Fuel Bundle 0074 with Rod Numbering Scheme $\quad$ • $\quad$ • $\quad$ •

A.2 Identification Marks for the Remaining Fuel Rod Clusters

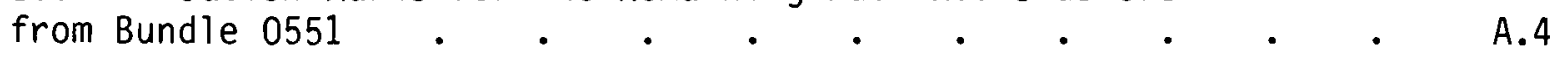

A.3 Schematic of Fixture Used to Puncture the Shippingport Fuel Rods. . . . . . . . . . . . . . A.8

A.4 Burst Test Fixture for the Shippingport Fuel Rods . . . . A.9 


\section{$\underline{T A B L E S}$}

1 Fabrication Data for Shippingport Blanket Fuel Bundles . . . 8

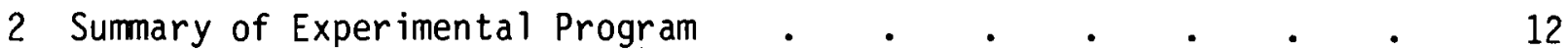

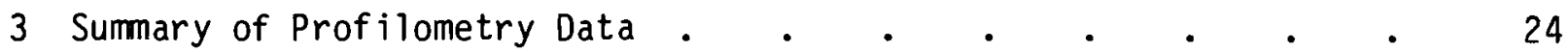

4 Summary of Internal Gas Contents and Compositions . . . . . 26

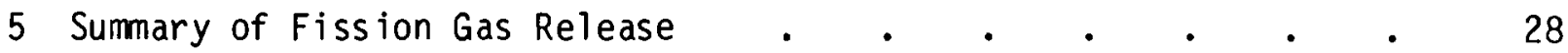

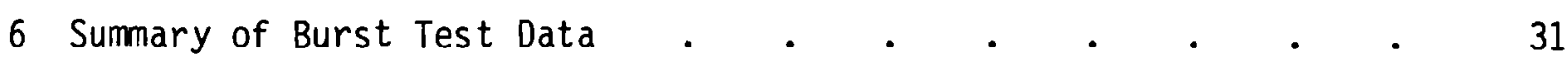

7 Comparison of Measured 0xide Film Thickness for

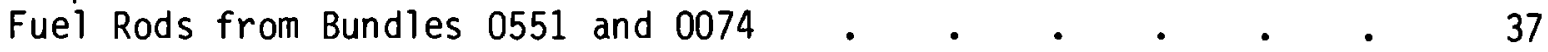

8 Summary of the Measured Hydrogen Content in the Shippingport Fuel Rod Cladding . . . . . . . 43

9 Hydrogen Content of Tube Sheet Samples from

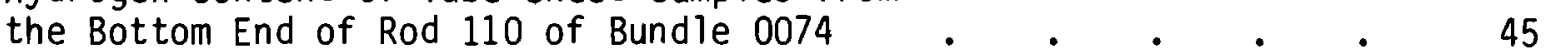

10 Comparison of Results from Hot Cell Examinations of Zircaloy-Clad Shippingport PWR Core 1 Blanket Fuel Rods . . 52

11 Fuel Assembly Degradation Mechanisms and How They Were Addressed in the Current Fuel Examinations . . . . . . 55

A.1 Correspondence Between BCL Rod Identification Number and Rod Position Within Bundle 0551. . . . . . . . . . . A.3

A.2 Correspondence Between BCL Sample Identification Number and the Sample Number Used in this Report . . . . . . . 


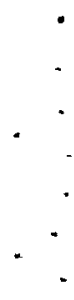


INTRODUCTION

Nuclear fuel resides in a reactor for 3 to $5 \mathrm{yr}$, and after discharge from the reactor the "spent" fuel continues to produce residual heat through radioactive decay of fission products. The fuel is stored in water pools because the water dissipates the residual heat and provides a radiation shield. Until recently, spent nuclear fuels were intended for reprocessing after interim storage (up to $2 \mathrm{yr}$ ) in water. However, the 1977 reprocessing moratorium in the United States left extended water storage as the only licensed fuel management option for commercial spent fuel.

Nuclear fuels are encased in metal to prevent release of nuclear reaction products into the environment. Previous experience from spent fuel pools, theoretical assessments of expected spent fuel behavior, and several destructive and nondestructive examinations of pool-stored spent fuel suggest that extended water storage of spent fuel is a viable technology. (a) This study extends the earlier investigations because it involved the world's oldest poolstored Zircaloy-clad fuel.

The Spent Fuel and Fuel Pool Component Integrity Program at Pacific Northwest Laboratory $(P N L){ }^{(b)}$ is currently examining spent fuel and pool equipment that has been in water storage for extended periods to characterize their durability and metallurgical condition. This report presents the results of hot cell examinations of two bundles of Zircaloy-clad spent fuel from the Shippingport Atomic Power Station. (c) The purpose of the examinations was to assess the effects of extended water storage (16 $\mathrm{yr}$ for one bundle and over $20 \mathrm{yr}$ for the other bundle) on the integrity of the Zircaloy cladding.

This report begins with the rationale for selection of the Shippingport fuel rods, their characteristics, and history. The next section presents the results of the current examinations; detailed experimental procedures are given

(a) Parker 1978; Hunt, Wood, and Bain 1979; Peehs et al. 1978; Huppert and Zimmerman 1977; Warner 1977; Flowers 1977; Johnson et al. 1980; Johnson 1977; Vesterlund and 01sson 1978; Mayman 1978; Huppert 1978.

(b) Operated for the U.S. Department of Energy (DOE) by Battelle Memorial Institute.

(c) A pressurized water reactor (PWR) located at Shippingport, Pennsylvania. 
in Appendix A. Current results are then compared with results of previous examinations of similar fuel soon after reactor discharge. Potential degradation mechanisms that were factored into the examinations are then discussed. Finally, plans are presented for future storage of the remaining fuel rods from the two bundles. 


\section{BACKGROUND INFORMATION}

The Spent Fuel and Fuel Pool Component Integrity Program at PNL is sponsored by DOE'S Division of Spent Fuel Storage and Transportation. As part of this program, PNL acquired candidate spent fuel to assess the effects of extended water storage on the integrity of Zircaloy fuel cladding. The Shippingport PWR Core 1 operated from 1957 to 1964. Blanket fuel from Core 1 was one of the candidates selected for detailed examination. The basis for selection, physical characteristics, irradiation history, and pool storage conditions are presented in this section.

\section{FUEL SELECTION}

The purpose of the current hot cell examination was to determine if discernible degradation of Zircaloy cladding occurs during extended pool storage. The metallurgical condition of the Zircaloy cladding immediately after reactor discharge is useful so that property changes that occurred in-reactor can be separated from those that occurred during pool storage. Since potential degradation mechanisms are expected to occur very slowly under pool storage conditions (Johnson 1977), fuels that have been stored for relatively long periods are needed to identify slow degradation that may be occurring. Other factors-such as burnup, power history, and fuel rod configuration--could influence spent fuel behavior and were considered in selecting fuel rods for the current examinations.

An extensive search for candidate fuels was conducted (Johnson et al. 1980). Fuel rods from commercial reactors of current design generally lack the detailed information regarding the condition of the cladding after discharge, and they have been stored for relatively short periods ( $<10 \mathrm{yr}$ ). Blanket fuel rods from the Shippingport PWR Core 1 loading are not typical of current commercial reactor fuels, but they do represent Zircaloy-clad uranium oxide fuel that has been stored in deionized water for almost $21 \mathrm{yr}$. More importantly, an extensive data base regarding their condition after discharge is available. Because these two criteria--prior examinations and long storage times--were considered essential for assessing the effects of extended water storage, the 
Shippingport fuel rods were selected for the current program. These data complement results from other spent fuel surveillance programs on fuel with less storage time. (a) specific information regarding their selection is given below.

\section{Prior Examinations}

The Shippingport Core 1 blanket fuel rods operated from 1957 through 1964. During this period, selected fuel bundles from high flux positions were removed from the reactor in 1959, 1961, 1963, and 1964 and destructively examined. (b) The 15 fuel rods from bundle 0551 that are included in the current program were part of a bundle examined in 1960 and thereby provide a direct basis for assessing the effects of nearly 21 yr of pool storage.

Several bundles of Core 1 blanket fuel rods were selected for additional exposure in the Multipurpose Extended Life Blanket Assembly (MELBA) test program. Bundle 0074 was a back-up bundle for this program and was visually examined after discharge from the reactor. Results from destructive examinations of fuel rods from bundle 0314, which was also discharged in 1964, provide the basis for assessing the effects of extended pool storage on the fuel rods from bundle 0074 .

Metallurgical examinations on early Shippingport Zircaloy-clad fuel rods during Core 1 operation established the effects of in-pile exposure and were useful in later examinations to determine the effects of extended water storage. Additional data regarding the effects of further in-pile exposure of similar fuel rods are available from the results of the MELBA test program (Hillner 1974; Hillner 1980) and involve fuel that remained in the reactor for $\sim 17 \mathrm{yr}$ (12.3 yr of reactor operation).

\section{Pool Storage}

Fuel bundle 0551 contains the world's oldest pool-stored Zircaloy-clad fuel rods. This bundle was discharged from the reactor in 1959, and the

(a) Parker 1978; Hunt, Wood, and Bain 1979; Peehs et al. 1978; Huppert and Zimmerman 1977; Warner 1977; Flowers 1977; Johnson et al. 1980; Johnson 1977; Vesterlund and 01sson 1978; Mayman 1978; Huppert 1978.

(b) Lynam 1963; Lynam 1964; Henke 1966; Rubin and Lynam 1966; Larson 1960; Rubin 1961(a); Rubin 1961(b); Sphar 1962; Lynam 1961; Lynam 1962. 
15 rods included in this examination had been stored in deionized water for nearly $21 \mathrm{yr}$ when they were reexamined. Bundle 0074 was discharged from the reactor in 1964 and had been stored in deionized water for $16 \mathrm{yr}$ at the time it was examined.

Burnup

Bundles 0551 and 0074 had estimated average burnups of $346 \mathrm{GJ} / \mathrm{kgU}$ (4000 MWd/MTU) and $1550 \mathrm{GJ} / \mathrm{kgU}(18,000 \mathrm{MWd} / \mathrm{MTU})$, respectively. Estimated peak rod burnups for bundle 0074 were approximately $2500 \mathrm{GJ} / \mathrm{kgU}(29,000 \mathrm{MWd} / \mathrm{MTU})$. (a) The burnups and 16 to $20 \mathrm{yr}$ of pool storage make these fuel rods attractive for assessing fuel rod integrity after extended water storage.

REACTOR OPERATION AND FUEL CHARACTERISTICS

The Shippingport Core 1 loading consisted of enriched metallic uranium seed assemblies surrounded by a region containing 791 blanket fuel bundles (see Figure 1). Seven blanket fuel bundles were stacked axially to form a fuel assembly; there were 113 blanket fuel assemblies in the reactor.

The blanket fuel bundles were fabricated by welding 120 individual fuel rods to Zircaloy-2 tube sheets at each end. The rods were arranged in an 11 by 11 square array with one corner rod removed for insertion of a failed element detection and location (FEDAL) system. The tube sheets on the welded bundles were machined to final dimensions of 132 by 132 by $260 \mathrm{~mm}$ ( 5.2 by 5.2 by $10.25 \mathrm{in.})$, and coolant flow holes were drilled between the fuel rods.

A schematic of the individual blanket fuel rods is shown in Figure 2, and pertinent fabrication data are given in Table 1 . Each rod contained 26 natural uranium dioxide pressed and sintered pellets that were 93 to $95 \%$ of theoretical density (TD). The fuel pellets were encased in Zircaloy-2 cladding that had an outside diameter (OD) of $10.44 \mathrm{~mm}$ and a nominal wall thickness of $0.64 \mathrm{~mm}$. The rods were filled with purified helium at ambient pressure, and Zircaloy-2 end plugs were welded to each end. The diametral gap ${ }^{(b)}$ between the fuel pellet

(a) Actual burnup on rod 110 of bundle 0074 was measured to be $3100 \mathrm{GJ} / \mathrm{kglU}$ (36,000 MWd/MTU) during the current examination.

(b) The diametral gap is cladding inside diameter (ID) minus pellet diameter. 


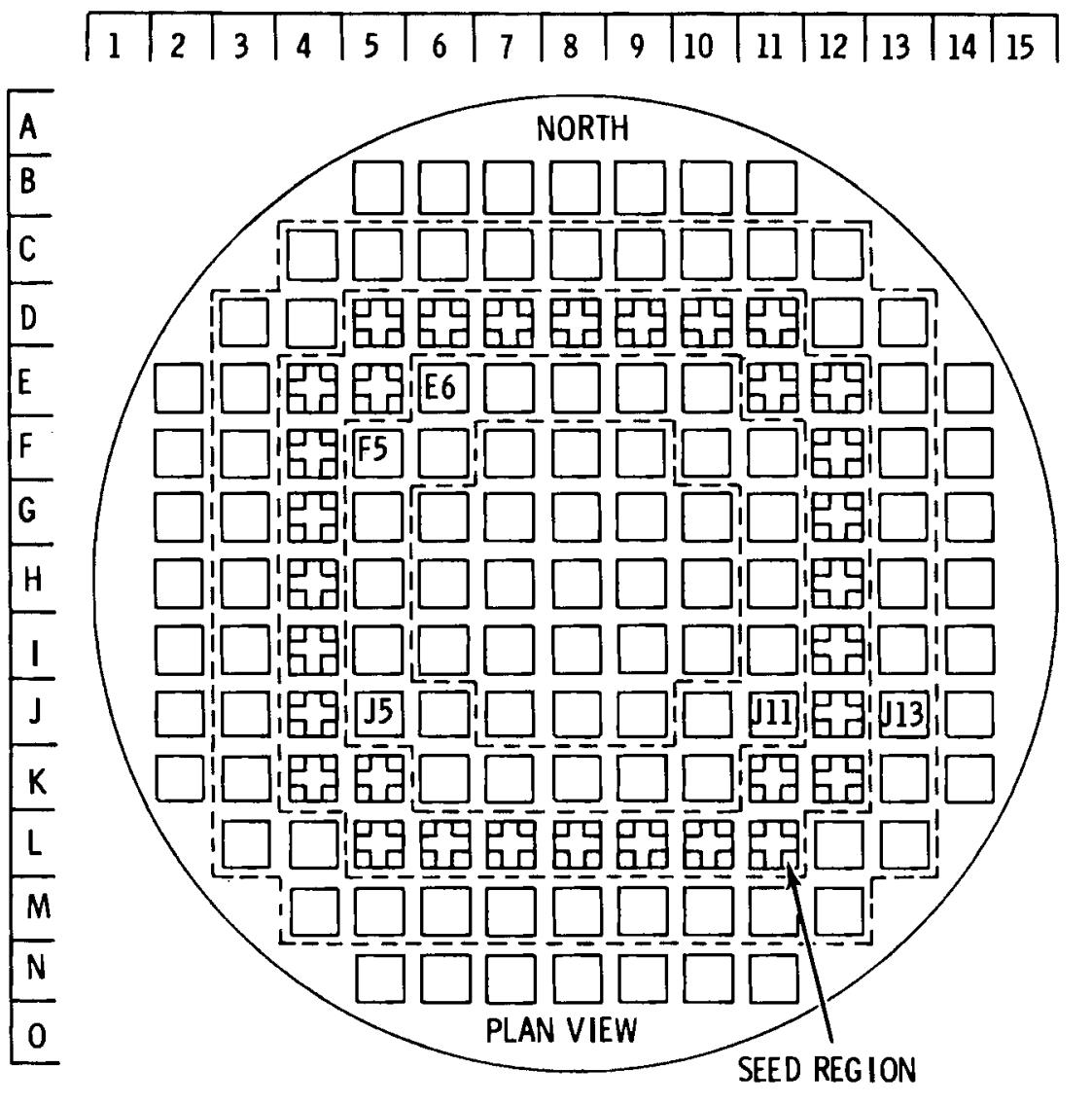
E6 - FUEL RODS EXAMINED AT END OF FIRST SEED AND AFTER 20 YEARS OF POOL STORAGE

$J 5$ - FUEL RODS EXAMINED AT END OF SECOND SEED

F5 - FUEL RODS EXAMINED AT END OF THIRD SEED

$J 11$ - FUEL RODS EXAMINED AT END OF FOURTH SEED

J13 - BUNDLE 0074 EXAMINED AFTER 16 YEARS OF POOL STORAGE

FIGURE 1. Schematic of Shippingport PWR Core 1 Cross Section

and cladding was nominally $0.1 \mathrm{~mm}$, and the axial clearance between fuel and end caps was 3.5 to $5.0 \mathrm{~mm}$. Further details regarding the fuel rod and fuel bundle fabrication are given by Glatter et al. 1958.

The first Shippingport PWR core reached full-power operation in December 1957 and operated until February 1964. The reactor was cooled and moderated with light water that was maintained at $\mathrm{pH} 10 \pm 0.5$, and the hydrogen concentration ranged from $10-$ to $60-\mathrm{ml} \mathrm{H}_{2}$ per kilogram of water. The inlet and outlet temperatures were $538 \mathrm{~K}\left(265^{\circ} \mathrm{C}\right)$ and $553 \mathrm{~K}\left(280^{\circ} \mathrm{C}\right)$, respectively; and the system was pressurized to $13.6 \mathrm{MPa}$ (2000 psi). 


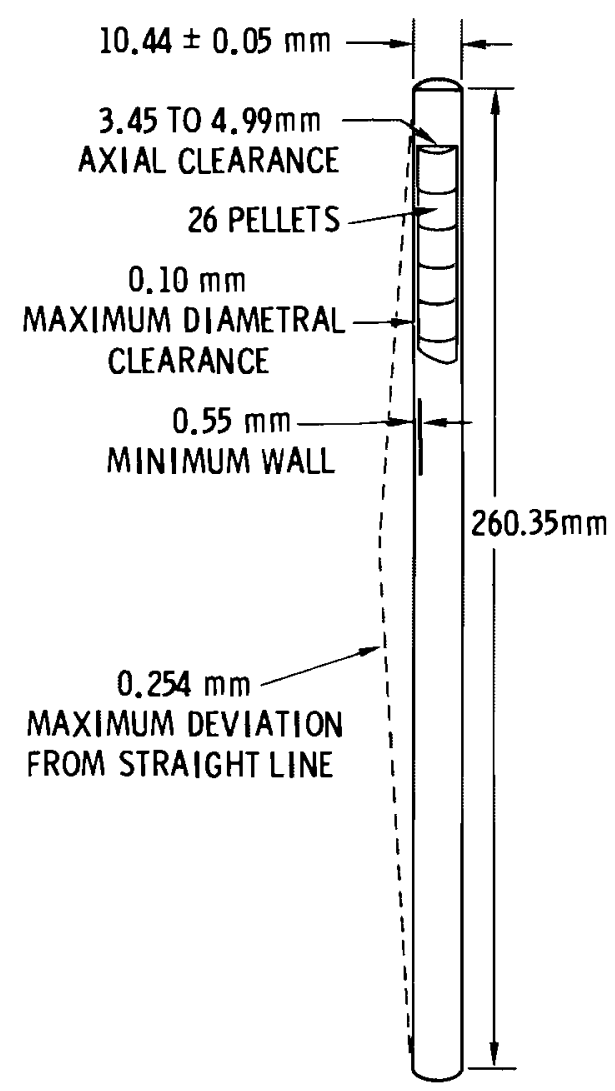

FIGURE 2. Shippingport PWR Blanket Fuel Rod

The enriched seed assemblies were replaced three times during the operating period from 1957 to 1964, and selected blanket fuel bundles were taken from the core for detailed postirradiation examination (PIE) during each refueling period. A blanket fuel bundle was also examined at the end of the first core operation. In all cases, fuel bundles were taken from high flux positions in the core, i.e., adjacent to seed assemblies (see Figure 1), and at the peak axial flux region, which occurred at the third bundle up from the bottom.

After Core 1 operation, several blanket fuel bundles were selected for continued exposure in Core 2 through the MELBA irradiation test program. Nine partially depleted blanket fuel bundles from the Core 1 loading were further irradiated in the central blanket region of Core 2. Three of the bundles were removed for destructive examination during the refueling outage (seed replacement) in 1969. The original six bundles plus three replacement bundles remained in the reactor until the end of the second core (1974) and were examined in the late 1970s. 
TABLE 1. Fabrication Data for Shippingport Blanket Fuel Bundles

Type (rod array)

$11 \times 11^{(a)}$

Fuel Rods (not prepressurized):

Number/Bundle

120

Length

$260 \mathrm{~mm}(10.25$ in.)

Out side Diameter

$10.44 \mathrm{~mm}(0.411 \mathrm{in.})$

Cladding Wall Thickness

$0.64 \mathrm{~mm}$ (0.025 in.)

Cladding Material

Zircaloy-2

Active Fuel Length

$231 \mathrm{~mm}(9.08 \mathrm{in.})$

Fuel Pellets:

Number/Rod

26

Diameter

$9.08 \mathrm{~mm}(0.357$ in.)

Length

$8.87 \mathrm{~mm}$ (0.349 in.)

Material

natural uranium dioxide

Density

10.1 to $10.3 \mathrm{~g} / \mathrm{cm}^{3}$

(a) One of the corner rods was removed for insertion of a failed element detection and location (FEDAL) system.

PIE of the Shippingport Core 1 blanket fuel rods and the related MELBA program provides what may be the world's most extensive data base for evaluating the in-pile corrosion performance of Zircaloy-clad fuel rods. Figure 3 indicates examination dates and pertinent references. An important feature of the data base is that fuel rods with similar characteristics were examined periodically after reactor residences ranging from 2 to $17 \mathrm{yr}$, thereby indicating how Zircaloy corrosion depends on reactor exposure (Hillner 1980).

The relationship between the present work and prior examinations is also shown in Figure 3. Fuel rods from bundle 0551 were destructively examined in 1960; 15 of the remaining rods were examined in the current program after nearly $21 \mathrm{yr}$ of pool storage. Bundle 0074 was not destructively examined in 1964 ; but bundle 0314, which was located directly across the seed assembly from bundle 0074 (see Figure 1), was examined and provides reference points for establishing the effects of water storage on Zircaloy-clad fuel rods from bundle 0074 . 


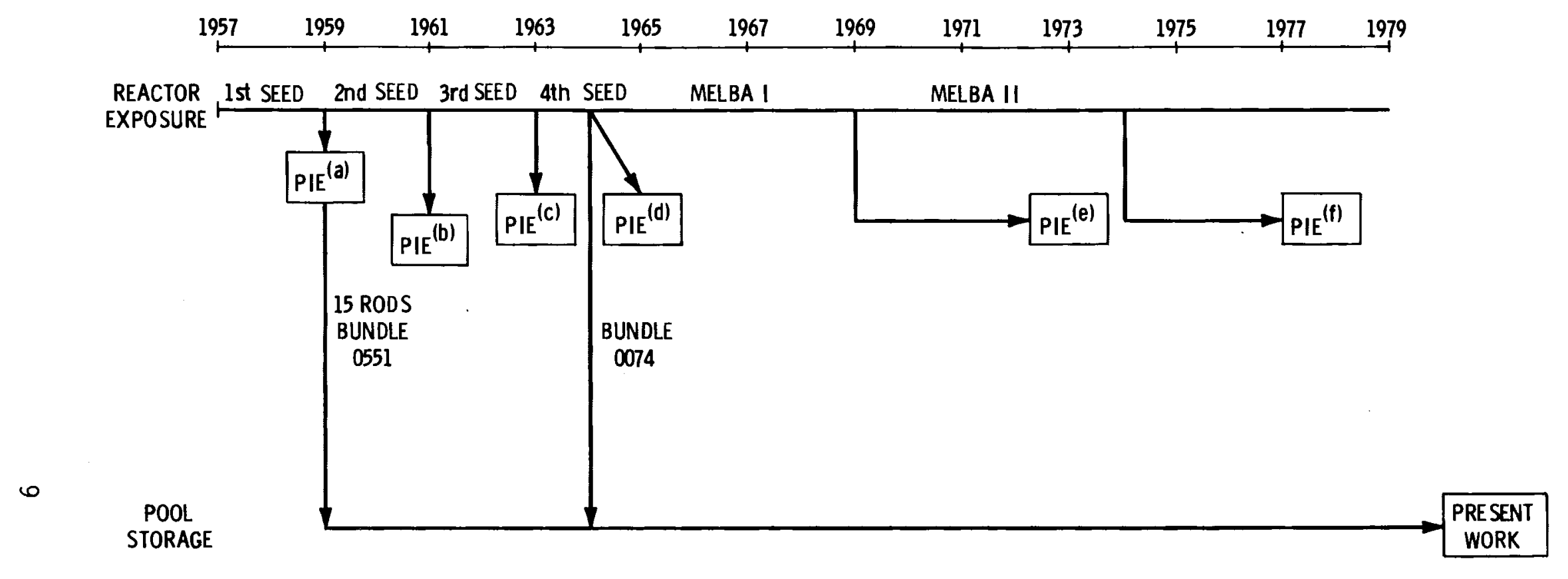

\section{REFERENCES}

(a) LARSON 1960; RUBIN 1961(a); RUBIN 1961(b); SPHAR 1962.

(b) LYNAM 1961; LYNAM 1963; LYNAM et al. 1962.

(c) LYNAM 1964.

(d) RUBIN AND LYNAM 1966; HENKE 1966.

(e) HILLNER 1974.

(f) HILLNER 1980.

FIGURE 3. Data Base for Shipp ingport PWR Core 1 Fuel Rods 


\section{POOL STORAGE CONDITIONS}

After reactor discharge, the fuel bundles were temporarily stored in the Shippingport canal, followed by shipment to the Expended Core Facility (ECF) at the National Reactor Testing Station, Idaho Falls, Idaho. Selected fuel rods from bundle 0551 were removed and destructively examined; bundle 0074 was visually examined. The remaining fuel rods from bundle 0551 and bundle 0074 were then stored in deionized water at the ECF storage pool for more than 20 and $16 \mathrm{yr}$, respectively.

Water temperatures at both the Shippingport canal and the ECF pool ranged from 288 to $298 \mathrm{~K}\left(15\right.$ to $25^{\circ} \mathrm{C}$ ) prior to 1973 . ECF pool temperatures have ranged from 280 to $288 \mathrm{~K}\left(7\right.$ to $15^{\circ} \mathrm{C}$ ) since 1973 ; this temperature range overlaps the ranges found in many spent fuel pools (Johnson 1977). The average temperature is lower, but the effects on oxidation are almost inconsequential. 0xidation measured at $360 \mathrm{~K}\left(87^{\circ} \mathrm{C}\right)$ on Zircaloy-2 process tubes in the Hanford K-East reactor, Hanford, Washington, was only $0.005 \mu \mathrm{m} / \mathrm{yr}$ (Dillon and Maffei 1965). This oxidation rate would produce a thickness increase of about $0.1 \mu \mathrm{m}$ after $20 \mathrm{yr}$, which is within the uncertainty of thickness measurements made by metallography.

\section{FUEL SHIPMENT}

Bundle 0074 and 15 fuel rods in two linear arrays from bundle 0551 were shipped from the ECF to the hot cells at Battelle-Columbus Laboratories (BCL) Nuclear Materials Technology Facility in July 1980. Prior to shipment, the exterior of the fuel rods was visually inspected and photographed by ECF personnel; no abnormal conditions were detected. The two fuel rod sections from bundle 0551 were wrapped in cloth to protect the fuel during shipment. The shipping cask atmosphere was moist air. The temperature during shipment is not known precisely but was probably less than $373 \mathrm{~K}\left(100^{\circ} \mathrm{C}\right)$. 


\section{0-1981 HOT CELL EXAMINATIONS}

The current hot cell examinations include a series of nondestructive and destructive examinations of fuel rods from two bundles (0551 and 0074) of Shippingport PWR blanket fuel that had been in pool storage for more than 20 and $16 \mathrm{yr}$, respectively. The purpose of the examinations was to assess the effects of extended water storage on fuel rod integrity; thus, the program was designed to allow direct comparison of the present results to those obtained after reactor discharge as well as to give special attention to potential degradation mechanisms identified by Johnson (1977).

Table 2 sumarizes the experimental program for the Shippingport fuel rods. Comparable results are available from previous investigations for each type of examination except gamma scanning and eddy current. These were . included in the present study to help establish fuel rod integrity, aid in selecting metallographic specimens, and provide a basis for future comparative examinations.

The fuel rod numbers listed in Table 2 represent the relative rod positions within the fuel bundle as shown in Figure 4 . The fuel rods from bundle 0551 consisted of rods 1 through 8 in one cluster and rods 13 through 19 in the second; all 120 rods from bundle 0074 were available for examination.

In selecting the eight fuel rods for detailed examination, consideration was given to the relative position of the fuel rods in the bundle and to the initial visual examination of the rods while they were still attached to the tube sheets. The four rods selected from bundle 0074 were adjacent to a seed assembly during reactor exposure; these rods represent the highest burnups

available. Visual inspection at the eight-rod cluster from bundle 0551 revealed a potential cladding crack in rod 5 . Although this apparent crack disappeared when viewed under different lighting conditions, this rod and rod 4 were selected for detailed examination. Rods 13 and 19 represent symmetric positions within the bundle, and their inclusion minimizes future handling during storage. 
TABLE 2. Summary of Experimental Program

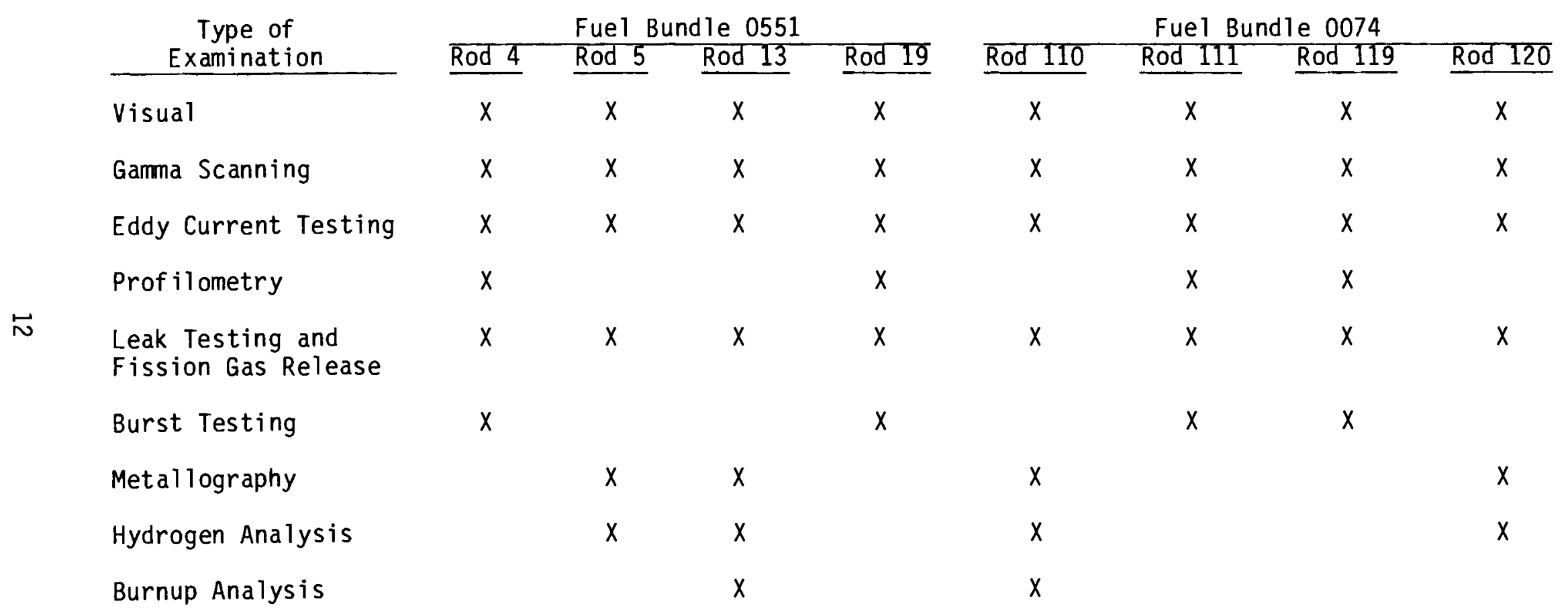




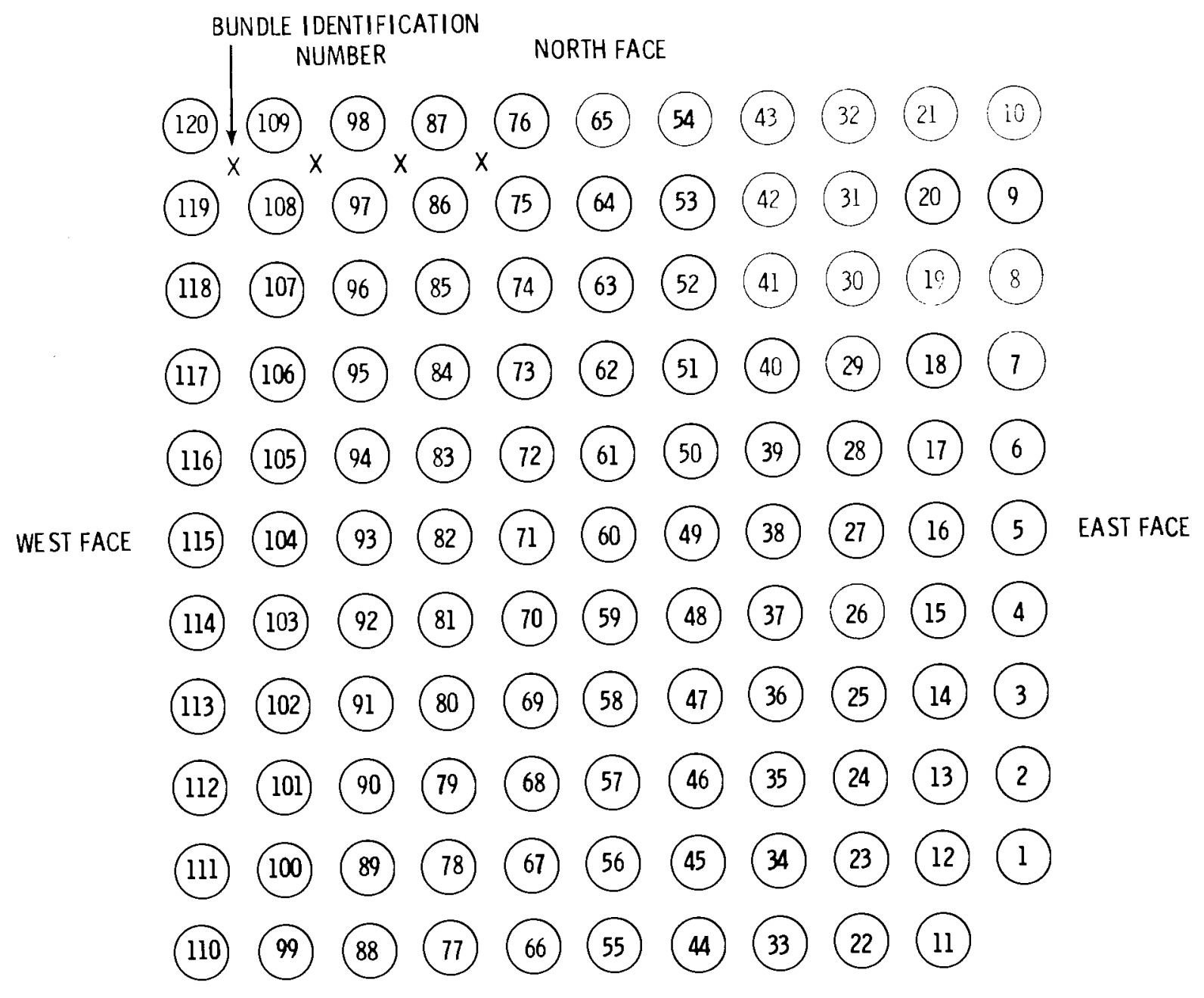

SOUTH FACE

TOP VIEW

FIGURE 4. Plan View of PWR Core 1 Blanket Fuel Bundle with Rod Numbering Scheme

Each fuel rod was subjected to a variety of examinations (see Table 2). The remainder of this section describes experimental operations used for the examinations and presents the results from each type of examination. Additional details of the experimental procedures are provided in Appendix $A$. 
EXPERIMENTAL OPERATIONS

The eight fuel rods selected for detailed examination were removed from the bundles with a circular saw in a milling machine by cutting the tube sheets between adjacent rods. The "squared ends" of each rod were machined in an incell lathe to form a right circular cylindrical shape, which was necessary to obtain profilometry traces and eddy current scans and to collect fission gases. Holes were drilled part way through one end cap along the rod axis to reduce the drilling distance required during puncturing for fission gas collection and to accommodate the high-pressure fitting needed for burst testing.

The entire length of the rods was visually examined at four orientations $\left(90^{\circ}\right.$ apart) around the circumference using a stereoviewer. The condition of the fuel rods was noted, and selected surfaces were photographed. The stereoviewer was also used to examine the exposed cladding surfaces of fuel rods in the bundle.

Eddy current examinations and axial gamma scans were made on all eight fuel rods. The eddy current testing utilized an encircling coil probe; a "standard tube" containing various machined defects was used for calibration. Both the gross gamma activity $(E>0.5 \mathrm{MeV})$ and ${ }^{137} \mathrm{Cs}(0.63$ to $0.68 \mathrm{MeV})$ were measured during the gamma scans. Scanning speeds for both the gamma scans and eddy current inspection were about $0.4 \mathrm{~mm} / \mathrm{s}$ ( $1 \mathrm{in./min}$ ).

Rod diameters and ovalities were measured on four of the fuel rods by spiral profilometry. The profilometer was calibrated with a standard rod containing precisely machined steps of different diameters and had an estimated. accuracy of $\pm 2.5 \times 10^{-3} \mathrm{~mm}( \pm 0.001 \mathrm{in}$.$) .$

The internal fuel rod gas content was determined by drilling a small hole through one end cap and measuring the pressure increase in an evacuated system of known volume. The released gases were collected into $\sim 30-m 1$ vials via a diffusion pump-Toepler pump combination, and the gas compositions were determined by mass spectroscopy. The amounts of xenon and krypton in the gas samples were compared to the amounts produced during irradiation to estimate the fractional fission gas released from the fuel. 
Samples for metallography, cladding hydrogen analysis, and burnup analysis were removed from the fuel rods using a water-cooled abrasive cut-off wheel. The metallographic samples were enclosed in a stainless steel supporting ring to minimize edge rounding and held in Bakelite mounts using a cold-setting epoxy resin. The samples were ground with silicon carbide abrasive papers, polished with a slurry of Linde $A$ alumina in a $2 \%$ chromic acid solution, and examined metallographically in both the as-polished and etched conditions. Etchants used for examination of the fuel microstructure consisted of 85 parts $\mathrm{H}_{2} \mathrm{O}_{2}$ and 15 parts concentrated $\mathrm{H}_{2} \mathrm{SO}_{4}$. A freshly mixed solution of 48 vol\% $\mathrm{H}_{2} \mathrm{O}_{2}(30 \%), 48$ vol $^{2} \mathrm{HNO}_{3}(70 \%)$, and 4 vol\% $\mathrm{HF}(48 \%)$ was used to reveal the microstructures of the Zircaloy cladding.

Hydrogen analysis samples were defueled, cleaned, and divided to allow duplicate analyses. Inert gas fusion--where the cladding sample is quickly heated to $2273 \mathrm{~K}\left(2000^{\circ} \mathrm{C}\right)$ in an argon atmosphere--was used. Impurity gases are selectively removed, and the resultant hydrogen content is determined by the difference in thermal conductivity of the sample gas and that of the pure argon reference gas. The system is calibrated using National Bureau of Standards (NBS) metal samples containing known quantities of hydrogen.

Fuel burnups were determined by completely dissolving the fuel and measuring the ${ }^{148} \mathrm{Nd}, U$, and $\mathrm{Pu}$ contents by a mass spectrographic analysis. Sample burnup was calculated according to ASTM-E-267 and ASTM-3-321 and is estimated to be accurate to within $\pm 5 \%$.

Burst tests were conducted on two fuel rods from each bundle using the same procedures as reported by Rubin (1961a). This involved slowly pressurizing the fuel rods with water through a small hole drilled in one end cap until bursting occurred. The burst specimens were photographed. Metallographic sections taken from the region of maximum strain enabled the failure strains to be determined.

\section{EXPERIMENTAL RESULTS}

\section{Visual Examination}

Upon arrival at $B C L$, bundle identifications were located and verified. The bundle number was stamped on the upper tube sheet surface of bundle 0074 
(see Figure 4), and two metal tags were attached to one of the fuel rods in each of the seven- and eight-rod clusters from bundle 0551. For the seven-rod cluster, the alphanumeric ECFR 887 was stamped on one tag and GE 055119 was stamped on the other. ECFR 893 and 05518 were stamped on the tags from the eight-rod cluster. The 0551 corresponds to the bundle number, and 8 and 19 represent the rod numbers to which the tags were attached.

The general appearance of the seven- and eight-rod clusters from bundle 0551 and the fuel rods in bundle 0074 is shown in Figure 5. A 3-mm diameter wire rope lifting cable $\mathrm{a}^{(\mathrm{a})}$ was inserted through the end plate holes at the southwest and northeast corners of bundle 0074 to facilitate handling in the storage pool. The cable was looped entirely through the bundle and clamped at one end and had a reddish-brown iron oxide surface deposit. Some reddish-brown deposits had also spread to the fuel rods and tube sheet areas adjacent to the cable. Energy dispersive $x$-ray analysis indicated that the wire composition was $99 \%$ iron, $0.6 \%$ manganese, $0.2 \%$ chromium, and about $0.2 \%$ trace elements.

Visual examination of fuel rod surfaces revealed no evidence of accelerated corrosion during storage. The cladding from bundle 0551 fuel rods was covered with an adherent black oxide that was very similar to that described by Rubin (1961a) for fuel rods from this bundle immediately after reactor discharge. Numerous scratches and handling marks were observed on all of the fuel rods from bundle 0551, and some crud deposits and water marks were also evident (see Figure 6).

Direct evidence of the excellent aqueous corrosion resistance of Zircaloy-2 was obtained by examining the tube sheets from the two clusters of bundle 0551 fuel rods. The tube sheets had been cut to remove these rods from the bundle in 1960; and the cut surfaces, which had been stored in water for more than $20 \mathrm{yr}$, showed no evidence of reaction with the water environment (see Figure 7).

The appearance of the fuel rods from bundle 0074 was similar to that of bundle 0551 except for the reddish-brown deposit from the lifting cable and

(a) The cable is not a part of the fuel bundle. 


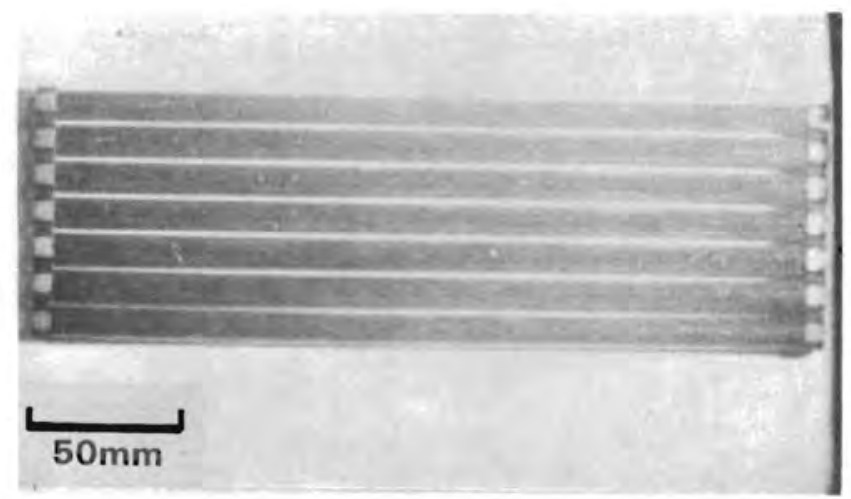

(a) Bundle 0551 - Appearance of Seven-Rod Cluster After Nearly $21 \mathrm{yr}$ of Pool Storage (Neg. C8311)

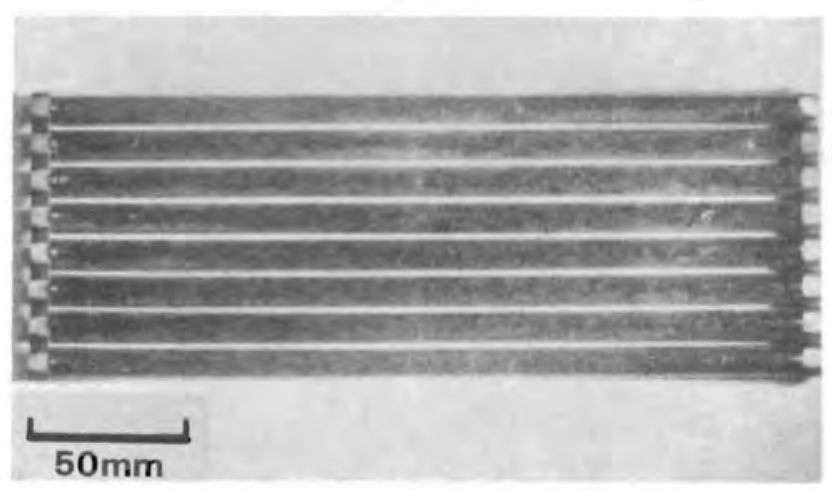

(b) Bundle 0551 - Appearance of Eight-Rod Cluster After Nearly 21 yr of Pool Storage (Neg. C8309)

\section{LIFTING CABLE}

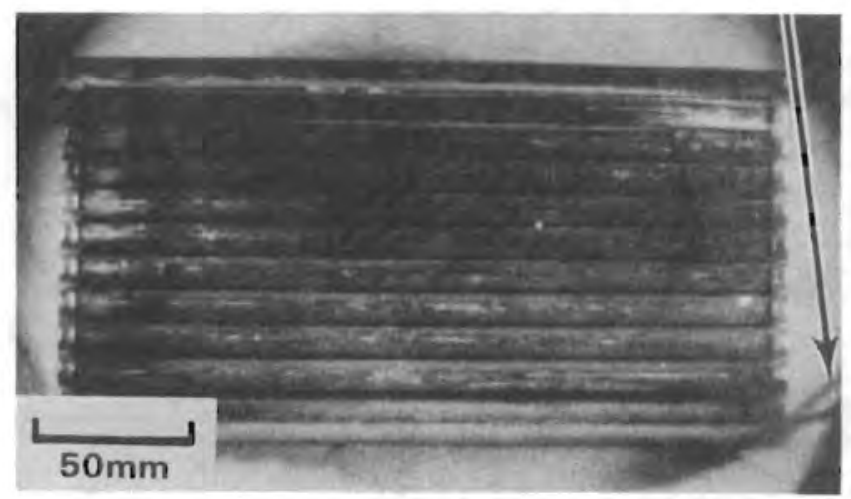

(c) Bundle 0074 - Appearance After 16 yr of Pool Storage (Neg. C8518)

FIGURE 5. General Appearance of Zircaloy-Clad Fuel Rods in Two Shippingport Fuel Bundles After Extended Water Storage 


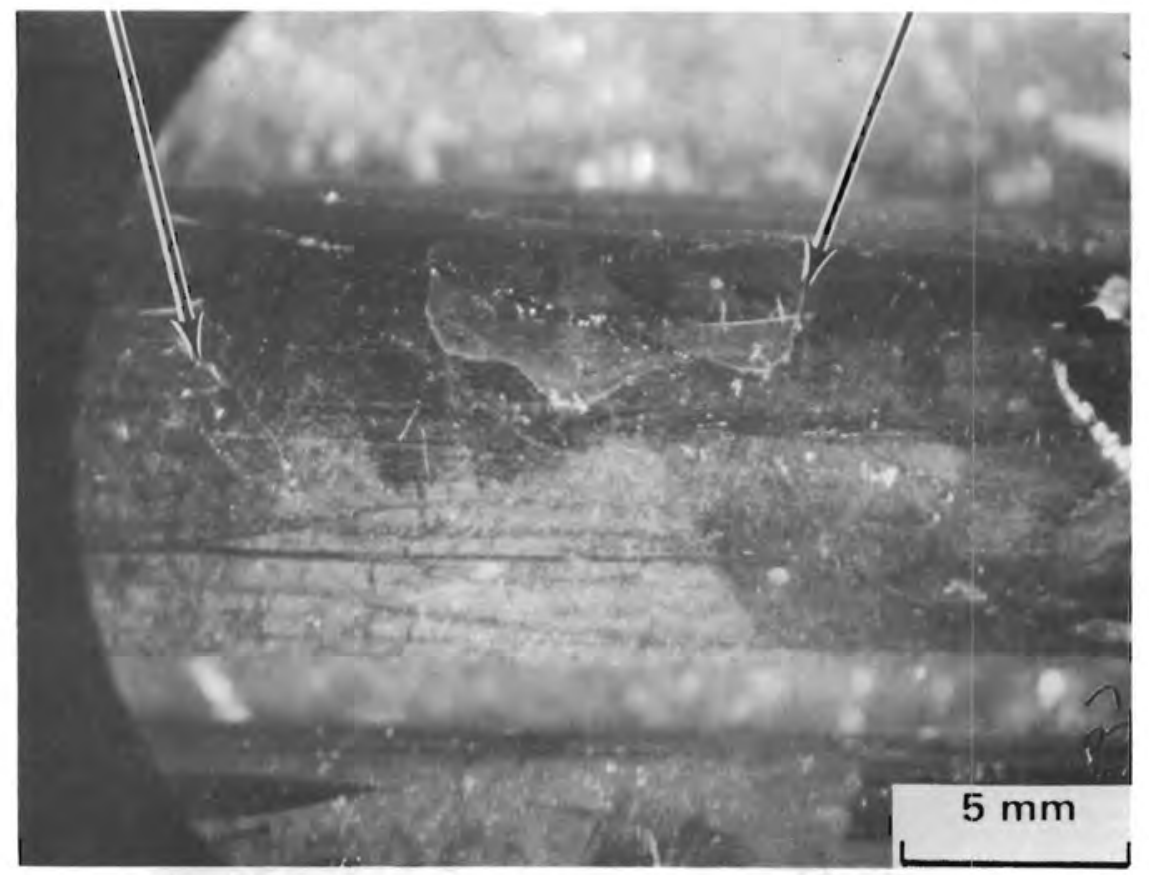

Neg. $C 8302$

Rod 8 - Bundle 0551

SCRATCHES CRUD OR WATER SPOT

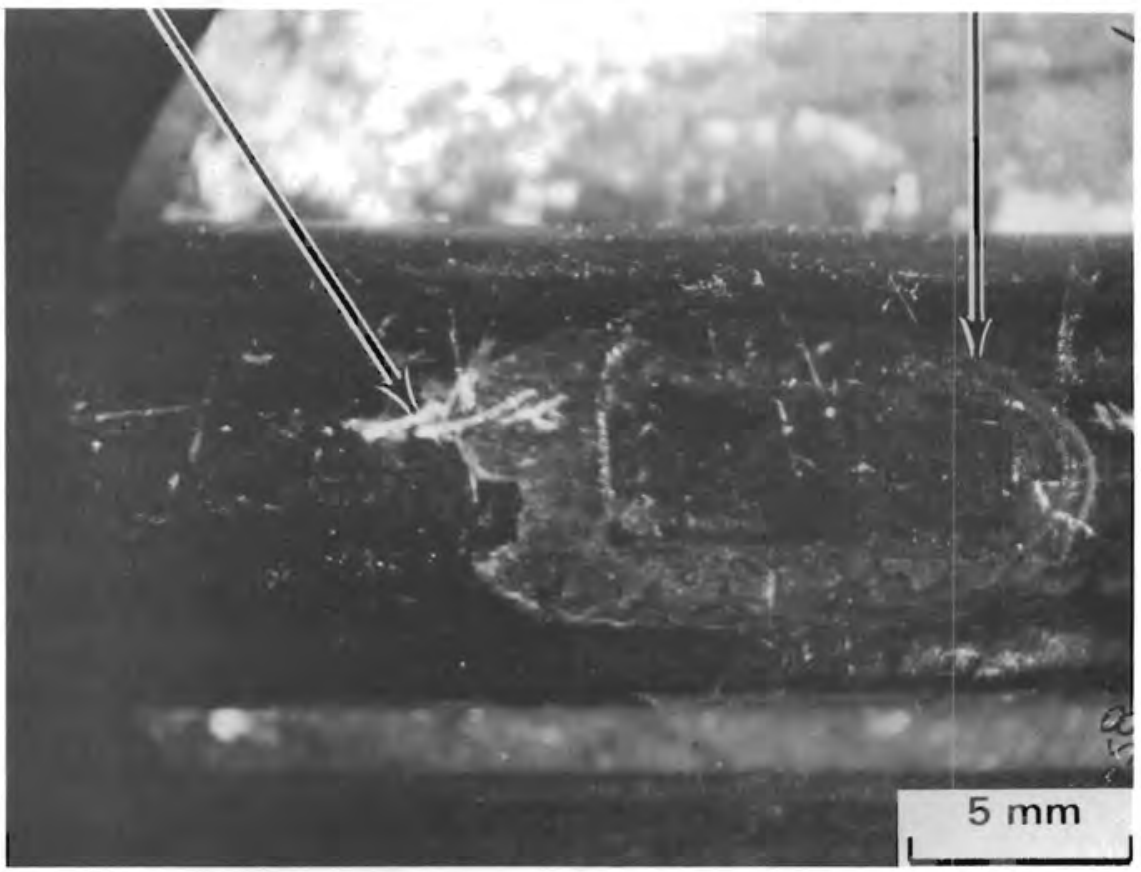

Neg. $C 8298$

Rod 18 - Bundle 0551

FIGURE 6. Typical Crud or Water Spots and Scratches on Fuel Rods from Bundle 0551 


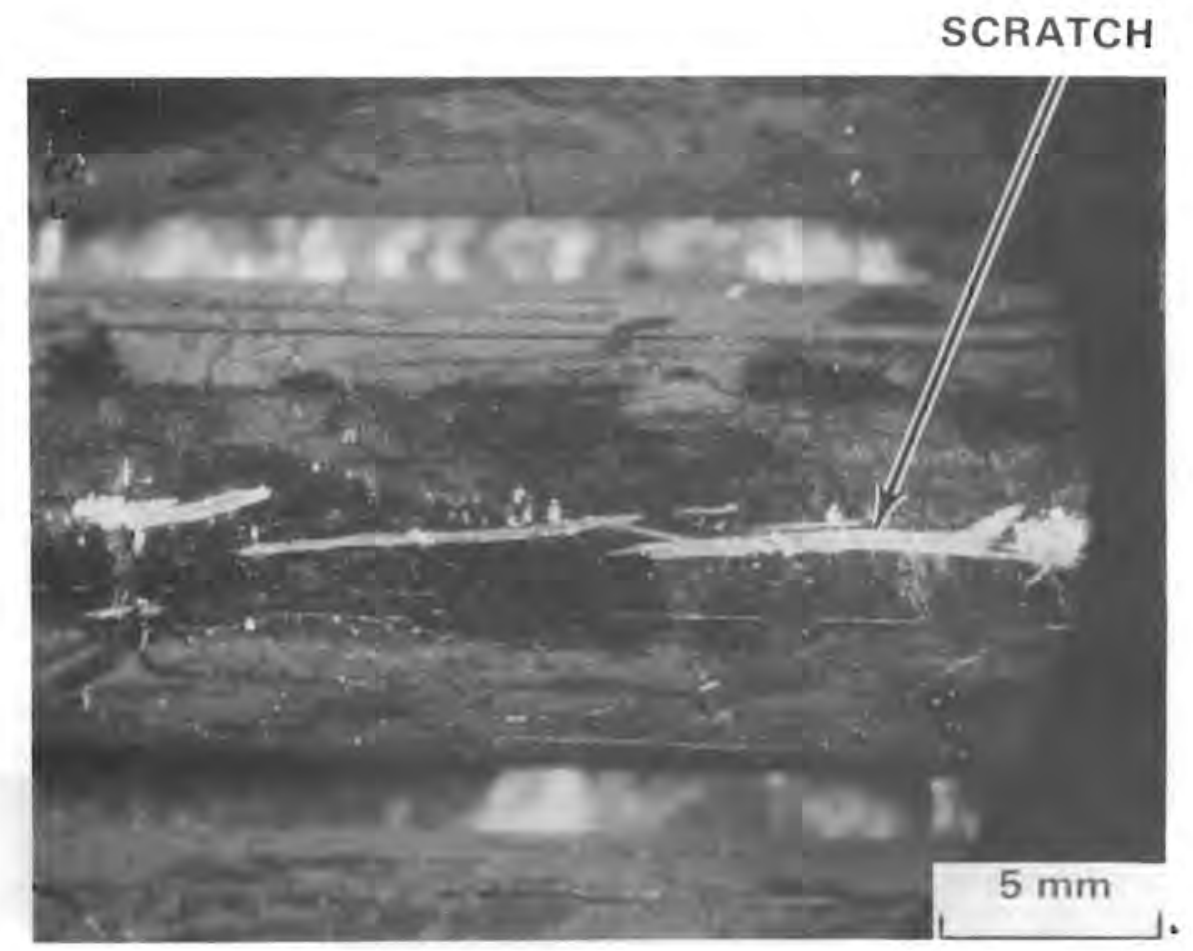

Neg. $\mathrm{C} 8303$

$$
\begin{aligned}
& \text { Rod } 6 \text { - Bundle } 0551 \\
& \text { FIGURE 6. (contd) }
\end{aligned}
$$

some gray oxide spots that appeared on many of the rods. Figure 8 shows the gray oxide spots on rod 117, which were relatively heavy near the upper end of this rod and rods 111 and 120. This type of corrosion film was observed on fuel rods after reactor discharge in 1964 (Henke 1966) and was described as a mottled corrosion film. The formation of this film was believed to be associated with the post-transition kinetic oxidation regime and was prevalent near the top of fuel rods that were adjacent to seed clusters. These observations are consistent with the visual examination of bundle 0074, which indicated that in-pile exposure was responsible for the formation of the gray oxide.

Scratches and handling marks, minor crud deposits, and water marks were also observed on the fuel rods from bundle 0074 . Rod 110 had a crud deposit and a small surface defect (see Figure 9), which was filled with the iron oxide deposit. The deposit was easily removed with a soft brush, leaving what appeared to be a superficial defect. Metallography confirmed the superficial nature of this defect. 
SURFACES CUT IN 1960

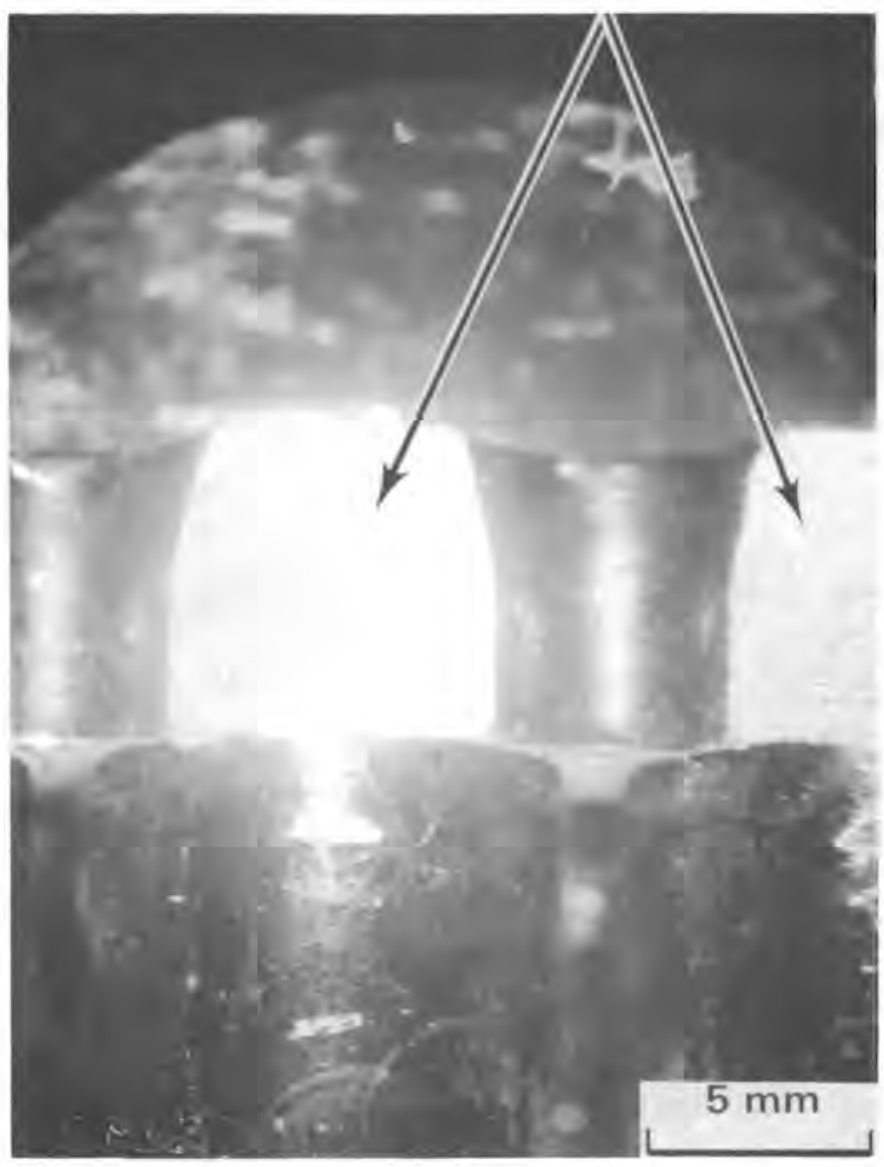

Neg. $C 8297$

Bundle 0551

FIGURE 7. Appearance of Tube Sheet Surfaces on Shippingport Fuel Bundle 0551; Cut in 1960 and Exposed to the Water Environment for $21 \mathrm{yr}$

Occasionally, surface markings, which appeared to be cracks in the cladding, were observed on fuel rods from both bundles. In all cases, however, the marks disappeared after brushing with distilled water. Figure 10 shows an area on rod 5 of bundle 0551 before and after brushing. When this area was examined after the rod was removed from the bundle, there was no evidence of a defect. The crack-resembling markings are believed to be associated with deposits produced when the fuel rods dried after removal to the hot cell.

After the eight fuel rods were removed from the bundles, each rod was visually examined under the stereoviewer at $90^{\circ}$ intervals around the circumference of the rod. Scratches, handling marks, and saw blade nicks were the only 


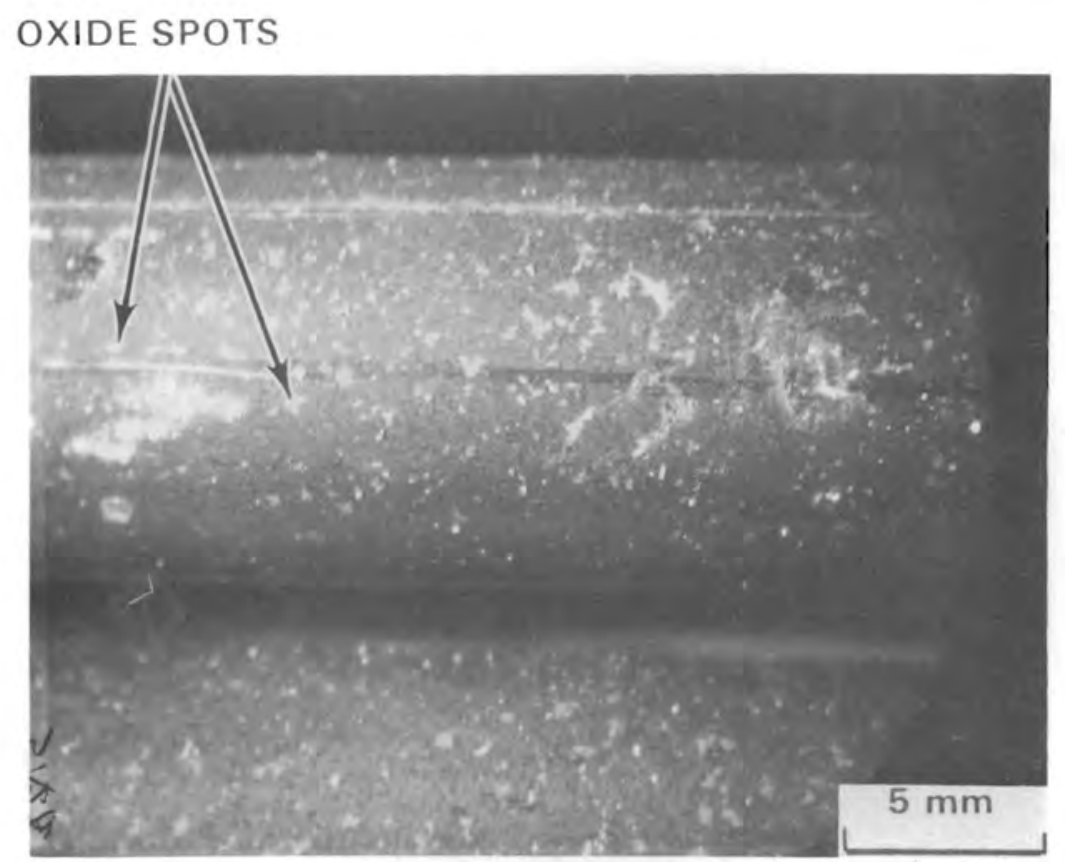

Neg. C8315

$$
\text { Rod } 112 \text { - Bundle } 0074
$$

FIGURE 8. Gray 0xide Spots on Rod 112 of Bundle 0074

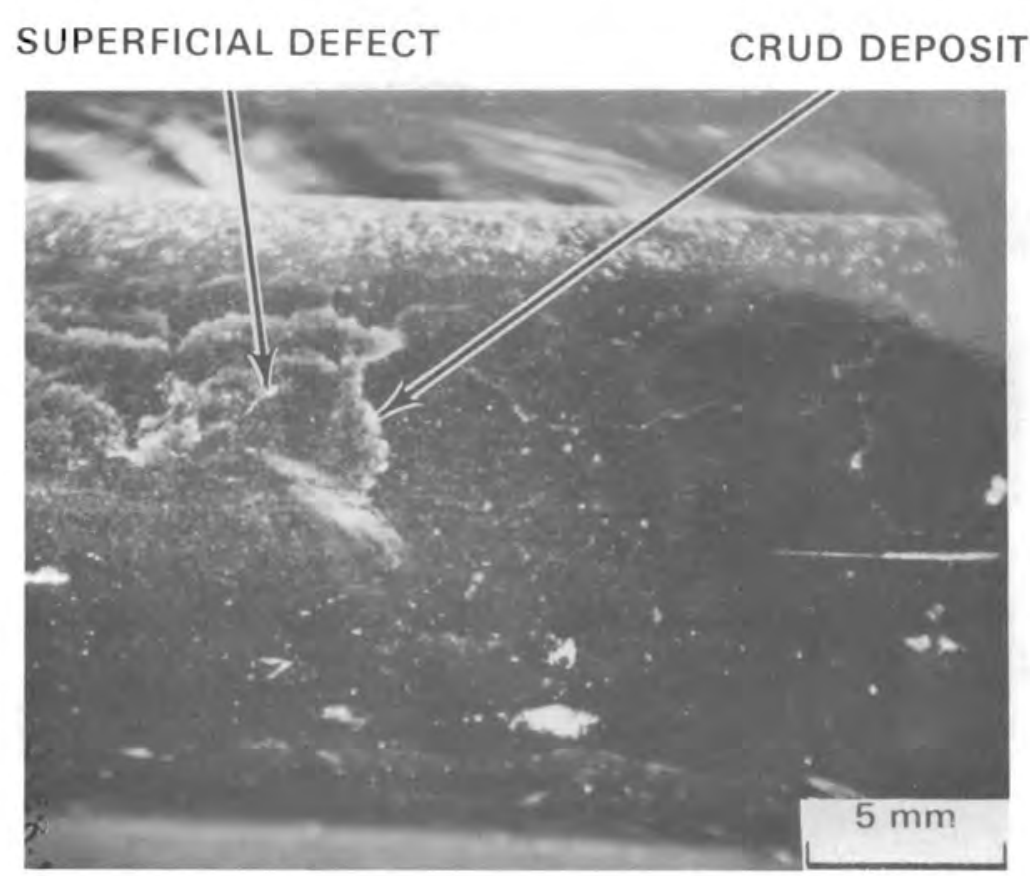

Neg. $C 8316$

$$
\text { Rod } 110 \text { - Bundle } 0074
$$

FIGURE 9. Superficial Defect on Rod 110 of Bundle 0074 
CRACK-LIKE SURFACE MARKING

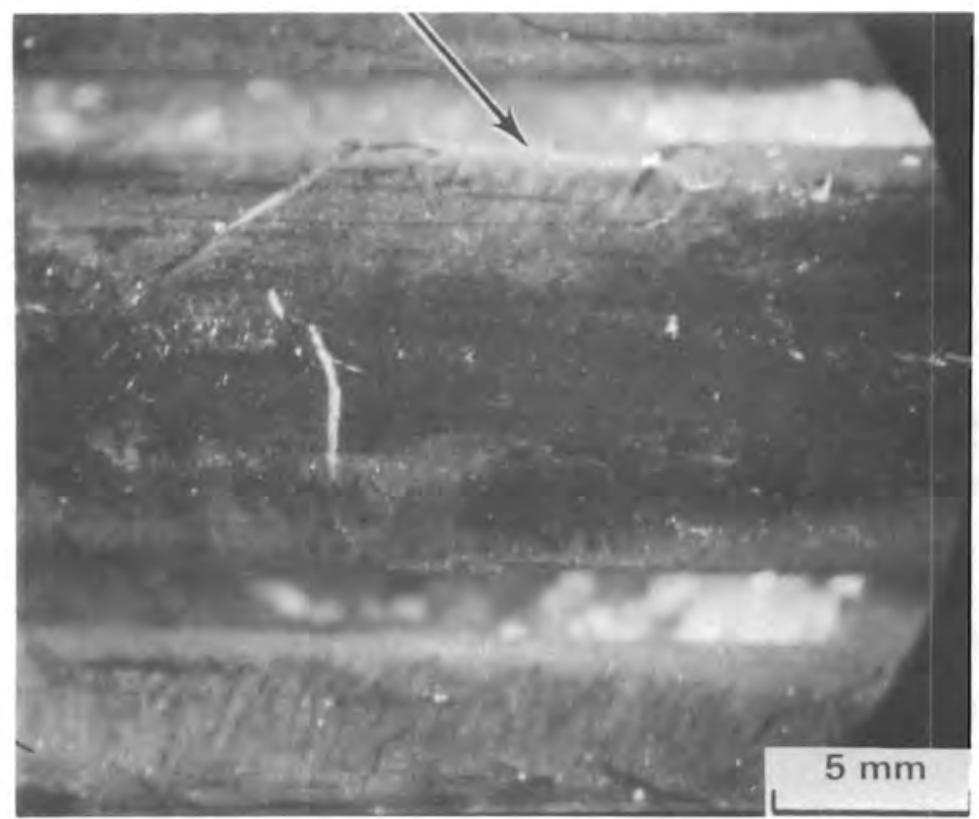

Neg. C8304

Bundle 0551 Before Brushing

LOCATION OF

PREVIOUS MARKING

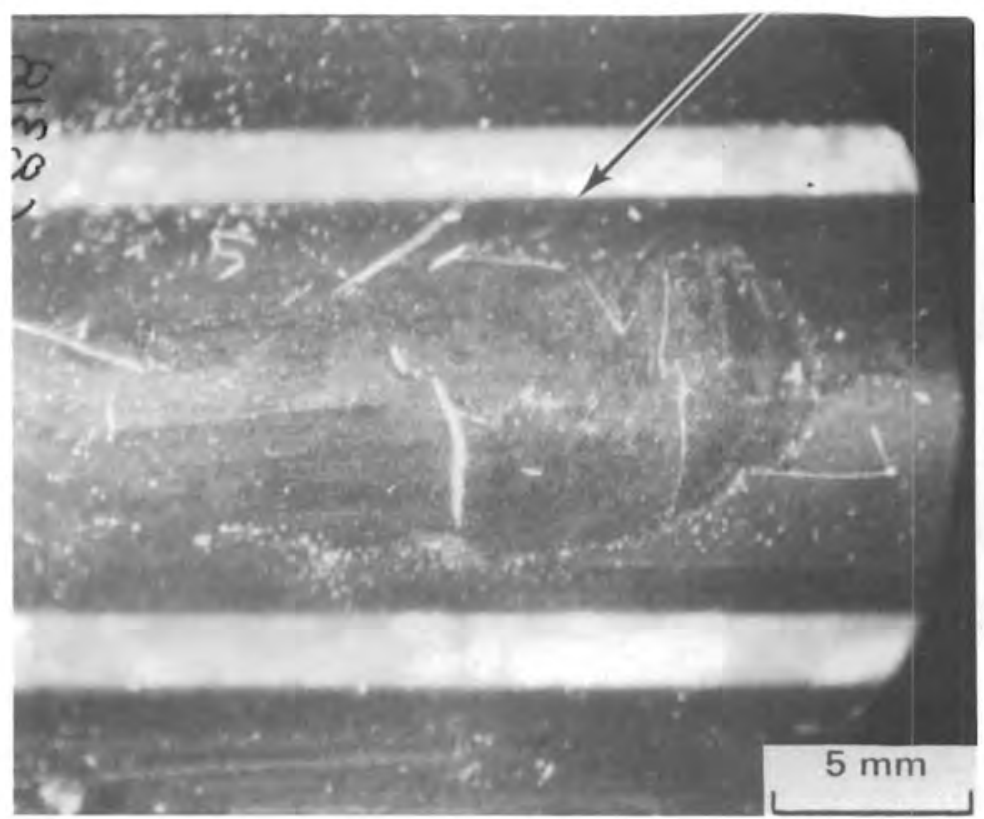

Neg. $C 8318$

Bundle 0551 After Brushing

FIGURE 10. Crack-Like Surface Marking on Rod 5 of Bundle 0551 
abnormal features noted during these examinations. No evidence of accelerated corrosion or cladding defects was seen on any of the fuel rods.

In summary, visual examination produced no evidence of accelerated corrosion or significant cladding defects on the fuel rods from bundles 0551 or 0074 after more than $16 \mathrm{yr}$ of pool storage. The corrosion films on both bundles appeared very similar to the films observed immediately after reactor discharge. The only defect identified (see Figure 9) was superficial, and the scratches and handling marks that were observed are an expected result of remote-handling operations.

Gamma Scanning

Results of axial gamma scans showed no unusual or unexpected behavior. The gross activity of the four fuel rods from bundle 0551 was only about 100 counts per second ( $c p s$ ) above the cell background and was quite constant along the rod axis. Higher activity levels (500 to $600 \mathrm{cps}$ above background) were recorded for the fuel rods from bundle 0074, which is consistent with the higher burnup and shorter decay times of these fuel rods. Several sharp dips in activity that were observed in each of the fuel rods from bundle $0074 \mathrm{can}$ be attributed to small axial gaps in the fuel column. No evidence of cesium segregation was detected in any of the eight fuel rods.

\section{Eddy Current Testing}

The results of the eddy current examinations showed no strong indications of defective cladding. Weak signal distortions (from two to six) were observed in seven of the eight fuel rods. The eighth rod--rod 120 of bundle $0074-$ showed evidence of cladding ridging at pellet interfaces along its entire length. Evidence of cladding ridging was also seen in the other three rods from bundle 0074 .

The eddy current technique is also sensitive to conditions other than defects, such as surface scratches, local variations in wall thickness or tube diameter, fuel-cladding bonding, and crud deposits (Bailey et al. 1981). Visual examination of the fuel rods showed that over $80 \%$ of the eddy current indications on the Shippingport fuel rods were directly associated with scratches or handling marks on cladding surfaces. Transverse metallographic 
sections from rods 5 and 13 of bundle 0551 were taken at three of the remaining locations, but no specific cause for the eddy current indications could be identified.

Profilometry

Spiral profilometry traces were used to measure the diameters and ovalities of the four fuel rods selected for subsequent burst testing (see Table 3 ). No evidence of defective cladding was observed in any of the profilometry traces.

The profilometry data showed that no significant changes in cladding dimensions had occurred during pool storage. The average diameters were within both the original manufacturing specifications-- $10.44 \pm 0.05 \mathrm{~mm}(0.411$ $\pm 0.002 \mathrm{in.}$ )--and the range of diameter measurements--10.33 to $10.64 \mathrm{~mm}(0.407$ to 0.419 in.)--from similar fuel rods immediately after reactor discharge.

Maximum ovalities were slightly higher than measured immediately after reactor discharge, but the small difference is most likely associated with the type of measurements made rather than a change in fuel cladding. In previous investigations, rod diameters were measured optically at 0 and $90^{\circ}$ orientations, which would not necessarily measure the maximum ovality as spiral profilometry does.

TABLE 3. Summary of Profilometry Data

$\begin{array}{cccc}\begin{array}{c}\text { Bundle } \\ \text { Number }\end{array} & \begin{array}{c}\text { Rod } \\ \text { Number }\end{array} & \begin{array}{c}\text { Average } \\ \text { Diameter, } \\ \text { mm }\end{array} & \begin{array}{c}\text { Maximum } \\ \text { Ovality, } \\ \text { mm }\end{array} \\ 0551 & 4 & 10.44 & 0.08 \\ 0551 & 19 & 10.44 & 0.10 \\ 0074 & 111 & 10.42 & 0.10 \\ 0074 & 119 & 10.42 & 0.15\end{array}$

Leak Testing and Fission Gas Release

The internal fuel rod gas content was determined by drilling a small hole through one end cap and measuring the pressure increase in an evacuated system 
of known volume. The released gases were collected into $\sim 30-\mathrm{ml}$ vials via a diffusion pump-Toepler pump combination. One vial was used for fuel rods from bundle 0551 while two vials, i.e., duplicate samples, were obtained for the 0074 fuel rods. Details of rod puncture and gas collection are given in Appendix A.

After the fission gases were collected, the fuel rods were leak checked by evacuating the system (including the fuel rod) and measuring the leak rate. The system was then pressurized to $0.27 \mathrm{MPa}$ (40 psi) with helium, and the pressure drop after a 5-min period was measured.

None of the eight fuel rods showed any evidence of leaking. Leak rates measured under vacuum ranged from 0.4 to $1.6 \mu \mathrm{m} / \mathrm{min}$, and in all cases these rates were less than the leak rates measured on the system prior to puncturing the rods. The maximum pressure loss during $5 \mathrm{~min}$ at $0.27 \mathrm{MPa}$ (40 psi) was $7 \times$ $10^{-5} \mathrm{MPa}(0.01 \mathrm{psi})$, which is within measurement uncertainty.

The content and compositions of the gas collected from the fuel rods are summarized in Table 4. Average values obtained from the 15 fuel rods from bundle 0551 that were examined in 1960 and reported by Rubin (1961b) are also presented in the table. Gas contents derived from the pressure measurements from bundle 0551 agree very well with the results obtained $20 \mathrm{yr}$ ago. Results that are directly comparable to bundle 0074 data are not available; but higher gas content is expected at higher burnup, which is consistent with the current results.

Comparing the gas content derived from the mass spectrographic analysis to that obtained from initial pressure measurements shows that a considerable amount of gas was introduced into some of the samples prior to the mass spectrographic analysis. The efficiency of the BCL gas collection system for these rods is expected to be less than the normal $95 \%$ because of the small gas content of the Shippingport fuel rods. Therefore, the higher gas content derived from the mass spectrographic analysis for rods 13 and 19 of bundle 0551 and rods 111 and 119 of bundle 0074 show definite evidence of sample contamination prior to mass spectrographic analysis. The major contaminants were nitrogen and oxygen, which suggests that air leaked into the samples either during the 
TABLE 4. Summary of Internal Gas Contents and Compositions

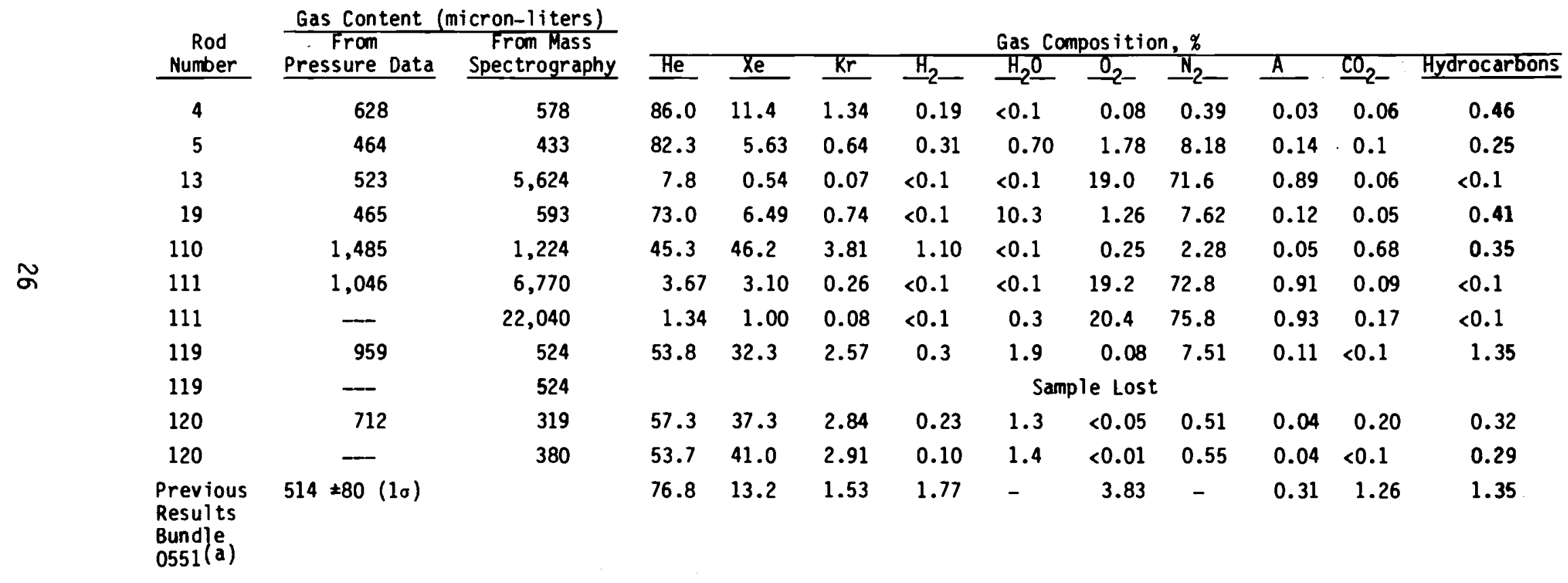

(a) Rubin 1961a. 
collection process or through the valve on the vials during the period between gas collection and analysis. The large difference in gas content between the duplicate samples from rod 111 indicate that leakage into the vials was the predominant source of the contamination. However, leakage into the system during gas collection could significantly alter the gas composition from these small fuel rods and is the probable source for some oxygen and nitrogen in all of the fuel rods.

Detailed examination of the data in Table 4 also indicates that the water that was detected in some of the gas samples did not originate from inside the fuel rods. For example, water content from two duplicate samples of rod 111 is 7 and 66 micron-liters, respectively, for samples 1 and 2. These two gas samples were collected simultaneously, and the large difference in water content could only occur by contamination after the fission gas was collected. Further evidence for an external source of water is obtained from the data for rod 19 of bundle 0551. For this rod, the nitrogen and oxygen content can account for only $41 \%$ of the difference between the total gas content derived from initial pressure data and mass spectrographic analysis. However, more than $90 \%$ of the difference is obtained when the water content is included, which indicates that water was introduced into the sample after the initial rod puncture.

The exact source of the water contamination could not be identified by examining the procedures used during gas collection and analysis. These same procedures and equipment are routinely used for collecting and analyzing fission gas samples with no water contamination being detected. However, the gas content of the Shippingport fuel rods is small compared to a normal fuel rod, which magnifies the effect of even small amounts of contamination.

The xenon and krypton contents of the fuel rods were used to estimate fission gas release with the results summarized in Table 5 . The estimated releases range from 0.2 to $0.5 \%$ with no significant difference between the fuel rods from bundles 0551 and 0074 . In making the calculations, the combined fission yields for xenon and krypton were assumed to be 0.3 and burnups were taken from the experimental results for rod 13 of bundle 0551 and rod 110 of bundle 0074 . 


\section{TABLE 5. Summary of Fission Gas Release}

\begin{tabular}{|c|c|c|c|}
\hline $\begin{array}{l}\text { Bundle } \\
\text { Number }\end{array}$ & $\begin{array}{c}\text { Rod } \\
\text { Number }\end{array}$ & $\begin{array}{r}\text { Burnup, } \\
\text { GJ/kgula })\end{array}$ & $\begin{array}{c}\begin{array}{c}\text { Fission Gas } \\
\text { Release, } \\
\%\end{array} \\
\end{array}$ \\
\hline $\begin{array}{l}0551 \text { (b) } \\
0551 \\
0551 \\
0551\end{array}$ & $\begin{array}{r}4 \\
5 \\
13 \\
19\end{array}$ & $\begin{array}{l}420 \\
420 \\
420 \\
420\end{array}$ & $\begin{array}{l}0.5 \\
0.2 \\
0.2 \\
0.3\end{array}$ \\
\hline $\begin{array}{l}0074 \text { (c) } \\
0074 \\
0074 \\
0074\end{array}$ & $\begin{array}{l}110 \\
111 \\
119 \\
120\end{array}$ & $\begin{array}{l}3100 \\
3100 \\
3100 \\
3100\end{array}$ & $\begin{array}{l}0.5 \\
0.4 \\
0.3 \\
0.3\end{array}$ \\
\hline
\end{tabular}

(a) $\mathrm{MWd} / \mathrm{MTU}=11.6 \mathrm{GJ} / \mathrm{kgJ}$.

(b) Burnup data for bundle 0551 are based on analysis of rod 13.

(c) Burnup data for bundle 0074 are based on analys is of rod 110 .

The fission gas release data reported by Rubin (1961b) for fuel rods from bundle 0551 ranged from 0.19 to $0.72 \%$, and the average release from 15 fuel rods was $0.37 \%$. These values compare very favorably with the current results and indicate that the fuel has not deteriorated and released additional fission gas.

\section{Burst Testing}

Two rods from each bundle were burst tested using the same procedures reported by Rubin (1961a) for fuel rods from bundle 0551, which involved slowly pressurizing the fuel rods with water through a small hole drilled in one end cap. To duplicate these procedures required making a special fixture to hold the fuel rods and a slight modification of the pressurizing system to use water. Details of the fixture and experimental procedures are given in Appendix A.

The fuel rods were pressurized in 13.8-MPa (2000-psi) increments up to $69 \mathrm{MPa}(10,000 \mathrm{psi})$ and continuously thereafter. The pressurization rate was about $0.11 \mathrm{MPa} / \mathrm{s}$ (1000 psi/min) with 1-min hold periods at each of the pressure increments. The purpose of the incremental hold periods was to assure pressure equalization along the fuel rod and to check for defective cladding (a pressure drop would be expected during the hold period if a leak existed). 
Results of the four burst tests are summarized below.

- None of the fuel rods showed any pressure drops during the hold periods, which indicates that no through-wall defects were initially present and that there was good pressure communication along the fuel rod axis.

- Bursting pressures for the four rods ranged from 99 to $105 \mathrm{MPa}$ $(14,400$ to $15,300 \mathrm{psi})$, and no significant differences between fuel rods from bundle 0551 and 0074 were observed.

- The fuel rods ruptured after 0.8 to $2 \%$ diametral strain producing axial cracks in the cladding. The ruptures initiated near the end caps, and the total crack lengths varied from 35 to $130 \mathrm{~mm}$ (1.4 to 5 in.); the longer cracks were observed in the fuel rods from bundle 0551. Typical burst failures for rods from the two bundles are shown in Figure 11.

The bursting pressures for the eight fuel rods ranged from 99 to $105 \mathrm{MPa}$ $(14,400$ to $15,300 \mathrm{ps} i)$, with no significant difference between fuel rods from bundle 0551 or 0074 . Table 6 summarizes burst test data from the current work and compares those data to information from prior examinations of fuel rods with similar exposures. Yield and fracture stresses were calculated using the relation:

$$
\sigma=\frac{P d}{2 t}
$$

where $\sigma=$ circumferential stress

$P=$ internal pressure at yielding or burst

$d=$ internal diameter $(9.195 \mathrm{~mm})$

$t=$ wall thickness $(0.635 \mathrm{~mm})$.

The internal diameters and wall thickness used in the calculations correspond to the values used by Rubin (1961a). Failure strains were determined by measuring the fuel rod circumference at the region of the initial failure and using the relation: 


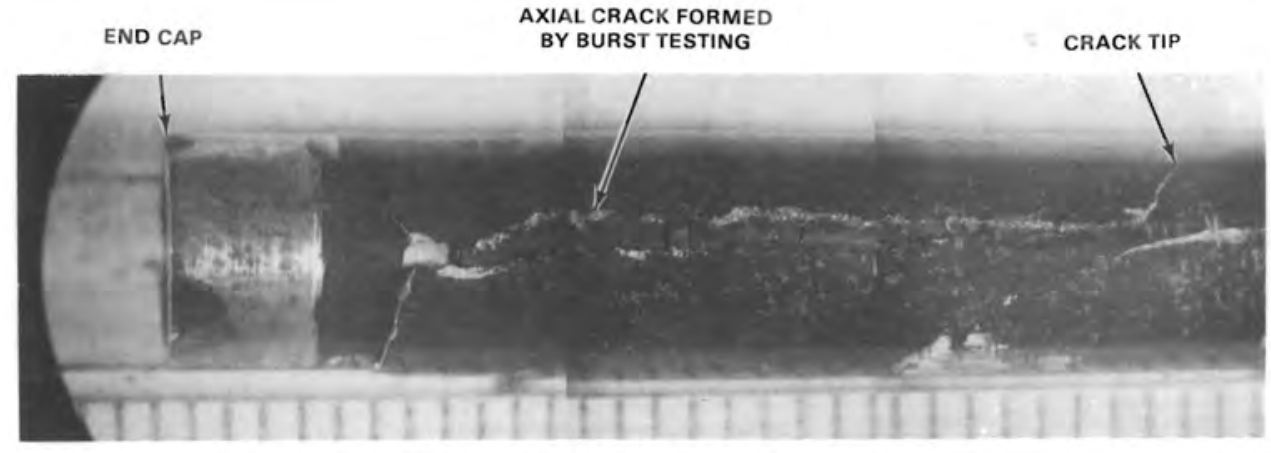

Rod 119 - Bundle 0074

END CAP $\quad$ AXIAL CRACK FORMED BY BURST TESTING

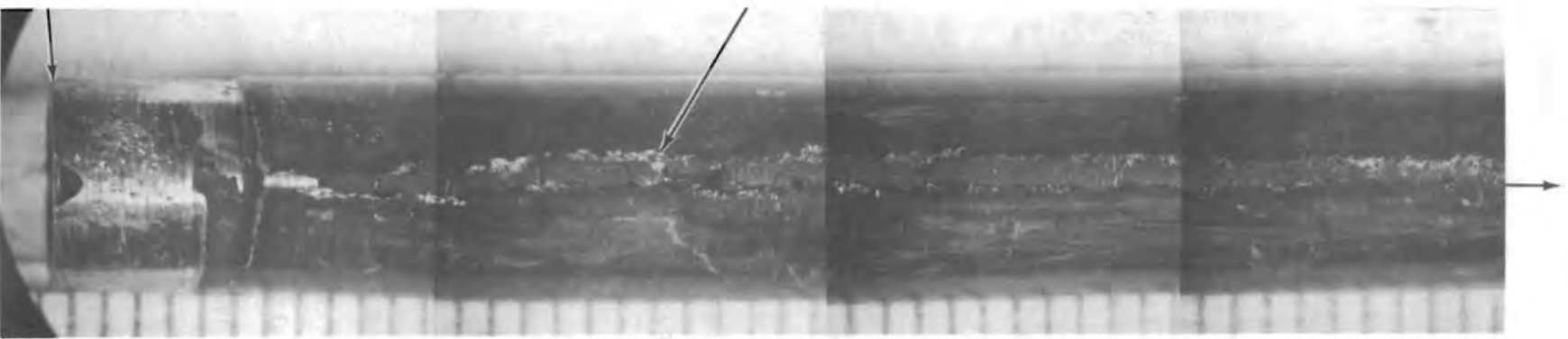

Rod 4 - Bundle 0551

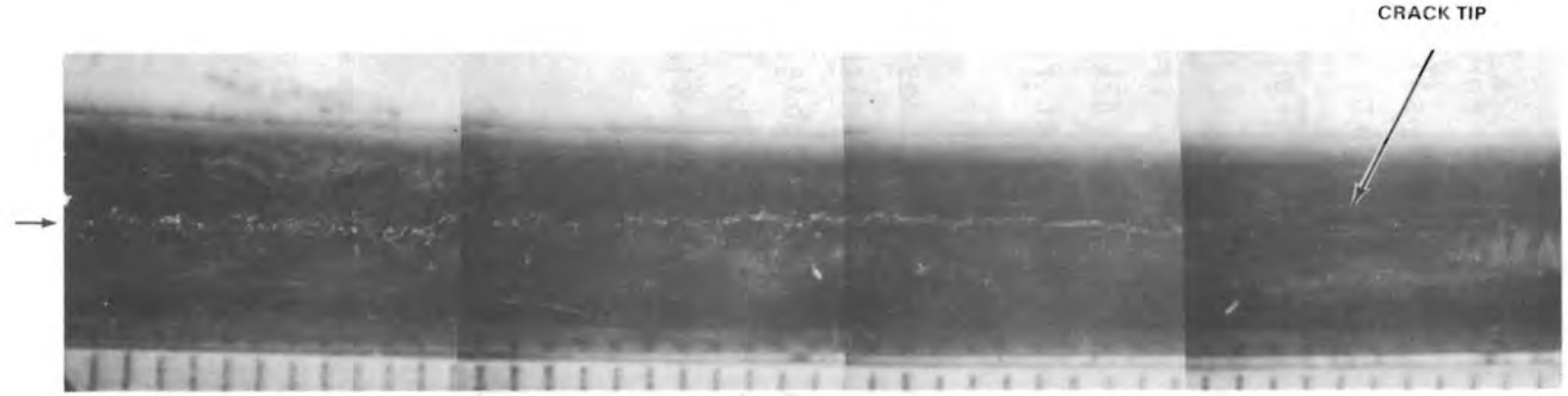

Rod 4 (contd)

FIGURE 11. Shippingport Fuel Rods 119 (Bundle 0074) and 4 (Bundle 0551) After Burst Testing 
TABLE 6. Summary of Burst Test Data

\begin{tabular}{|c|c|c|c|c|c|c|}
\hline \multirow{2}{*}{$\begin{array}{l}\text { Bund le } \\
\text { Number } \\
\end{array}$} & \multirow{2}{*}{$\begin{array}{c}\text { Rod } \\
\text { Number } \\
\end{array}$} & \multicolumn{2}{|c|}{$\begin{array}{c}\text { Internal Pressure, } \\
\mathrm{MPa}\end{array}$} & \multicolumn{2}{|c|}{$\begin{array}{c}\text { Calculated Stress, } \\
\mathrm{MPa}\end{array}$} & \multirow[b]{2}{*}{ Failure Strain, $\%$} \\
\hline & & $0.2 \%$ Yield & Burst & $0.2 \%$ Yield Stress & Failure Stress & \\
\hline 0551 & 4 & 95 & 103 & 688 & 746 & 2.2 \\
\hline 0551 & 19 & 95 & 105 & 688 & 760 & 1.0 \\
\hline $\begin{array}{l}\text { Prior Work } \\
\text { Bund le } 0551\end{array}$ & & - & 92 to 103 & - & 666 to 746 & - \\
\hline 0074 & 111 & 97 & 104 & 702 & 751 & 0.77 \\
\hline 0074 & 119 & 94 & 99 & 682 & 716 & 1.24 \\
\hline $\begin{array}{l}\text { Prior Work (b) } \\
\text { Bundle } 0314\end{array}$ & & & 99 and 102 & & 716 and 737 & 0.17 and 0.24 \\
\hline
\end{tabular}

(a) $\mathrm{MPa}=0.145 \mathrm{ksi}$.

(b) Data supplied by R. Atherton, Bettis Atomic Power Laboratory, West Mifflin, Pennsylvania. 


$$
\varepsilon=\frac{C_{f}-C_{i}}{C_{i}}(100)
$$

where $\varepsilon=$ failure strain

$C_{f}=$ rod circumference after burst test

$C_{i}=$ initial rod circumference $(32.8 \mathrm{~mm})$.

The data in Table 6 show no evidence of cladding degradation caused by pool storage. The bursting pressures from the present work are within the range of values for similar fuel rods examined after reactor discharge. Although the failure strains were not reported for the fuel rods from bundle 0551 examined after reactor discharge, the general appearance and characteristics of the failures are very similar to those reported previously (Rubin 1961 a; Lynam 1963).

Metallography and Hydrogen Analysis

Two rods from each bundle were sectioned for metallographic examination and hydrogen analysis of the cladding as shown in Figure 12. Longitudinal metallographic sections were taken through the bottom end caps of rod 5 of bundle 0551 and rod 120 of bundle 0074. In addition, six transverse metallographic specimens (three from fuel rods of each bundle) were examined; and in all cases, samples for hydrogen analysis of the cladding were taken from regions adjacent to the metallographic specimens.

The bottom end of rod 110 (bundle 0074) had been in contact with the steel lifting cable, and samples for hydrogen analysis and metallography were taken from this region to check for accelerated corrosion and hyriding caused by the galvanic couple. Three samples for hydrogen analysis and one metallographic specimen were taken from a 3-mm thick transverse section as shown in Figure 13.

Nondestructive examination results were used to identify the locations for the transverse metallographic samples. For rod 5 from bundle 0551, two small eddy current indications were observed within this sample location and the crack-like surface marking that disappeared upon brushing extended through this region. Small eddy current indications were also observed within 

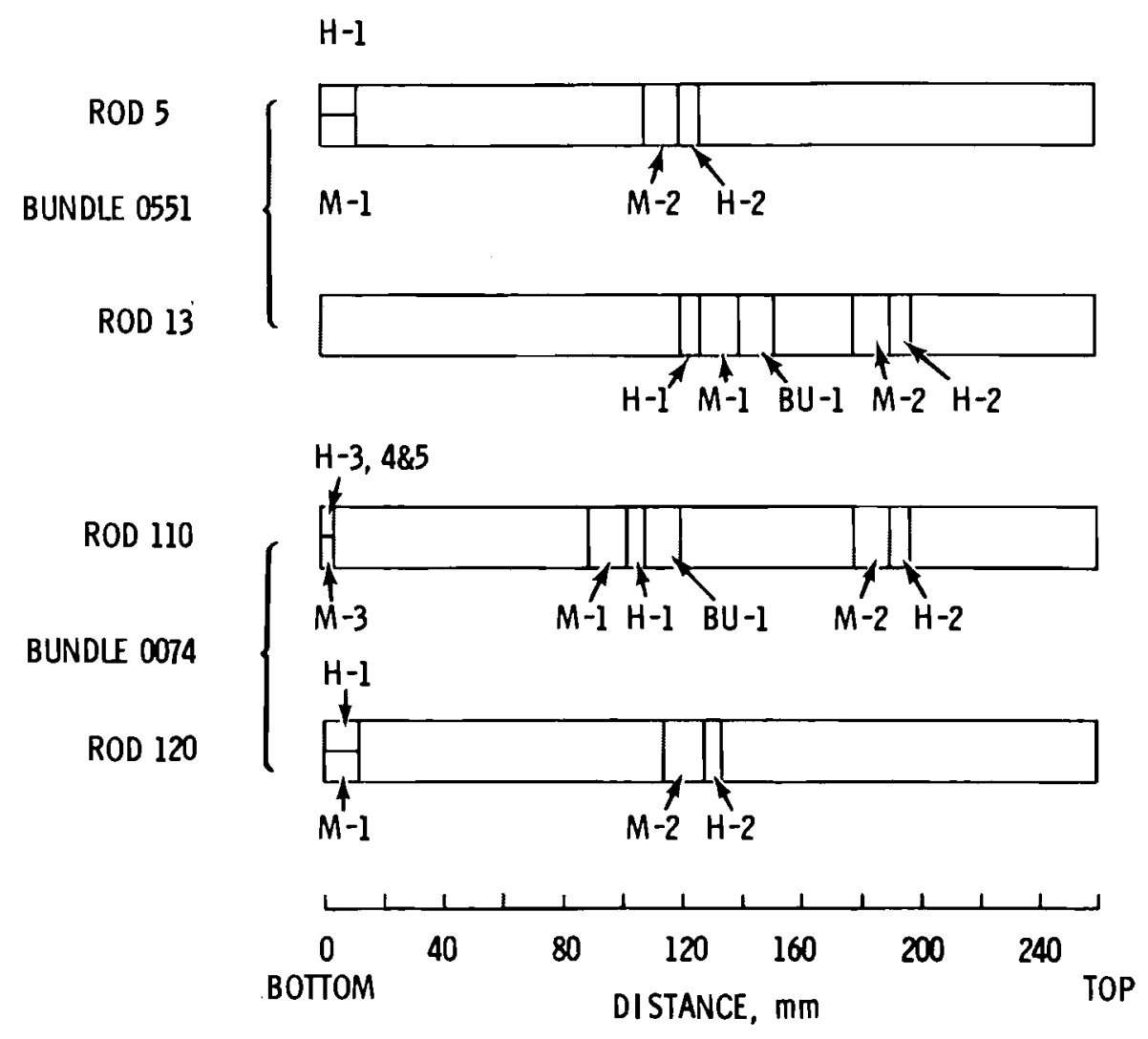

FIGURE 12. Cutting Diagram for Shippingport Fuel Rods

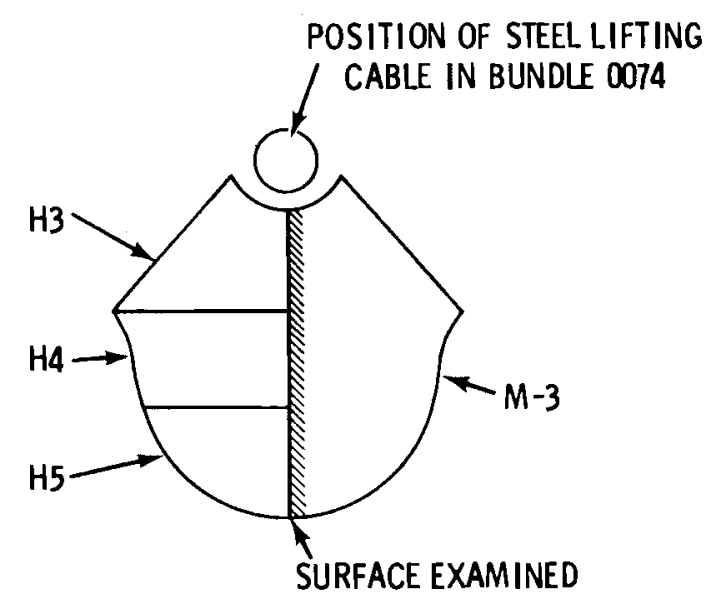

FIGURE 13. Cutting Diagram for 3-mm Thick Slice from the Bottom End of Rod 110 of Bundle 0074 
samples M-1 and M-2 of rod 13 of bundle 0551. For fuel rods from bundle 0074, all transverse metallographic samples contained regions where significant dips corresponding to pellet interfaces were observed in the gamma scans. Pellet interfaces represent potential regions for pellet-cladding interactions and thereby increase the probability of finding cladding defects at these locations. Sample M-2 from rod 110 also contained the surface defect that was shown in Figure 9.

The transverse metallographic specimens were progressively ground, polished, and examined at intervals ranging from 0.5 to $1.0 \mathrm{~mm}$ whereas one surface from the longitudinal sections was examined. During the examinations, special attention was given to the following regions:

- external cladding surfaces

- internal cladding surfaces

- hydride distribution

- welds

- $\mathrm{UO}_{2}$ fuel.

No evidence of cladding degradation caused by water storage was observed during the examinations. The results for each of the above regions are presented and discussed below.

\section{External Cladding Surfaces}

The predominant feature of the external cladding surfaces was a thin oxide film (see Figure 14) for fuel rods from bundles 0551 and 0074 . An occasional crud deposit was observed on some of the samples, but no evidence of accelerated corrosion underlying the crud deposits was detected. As expected from the visual examinations, small scratches through the oxide films were observed on all of the specimens. No evidence of Zircaloy corrosion was seen at the exposed surfaces; but it is uncertain when the scratches were made and the surfaces may or may not have been exposed during storage.

The abnormal surface marking on rod 110 (shown previously in Figure 9) was located and examined. It appeared to be a superficial, 50-um deep scratch or gouge that had filled with crud during reactor exposure (see figure 15). 


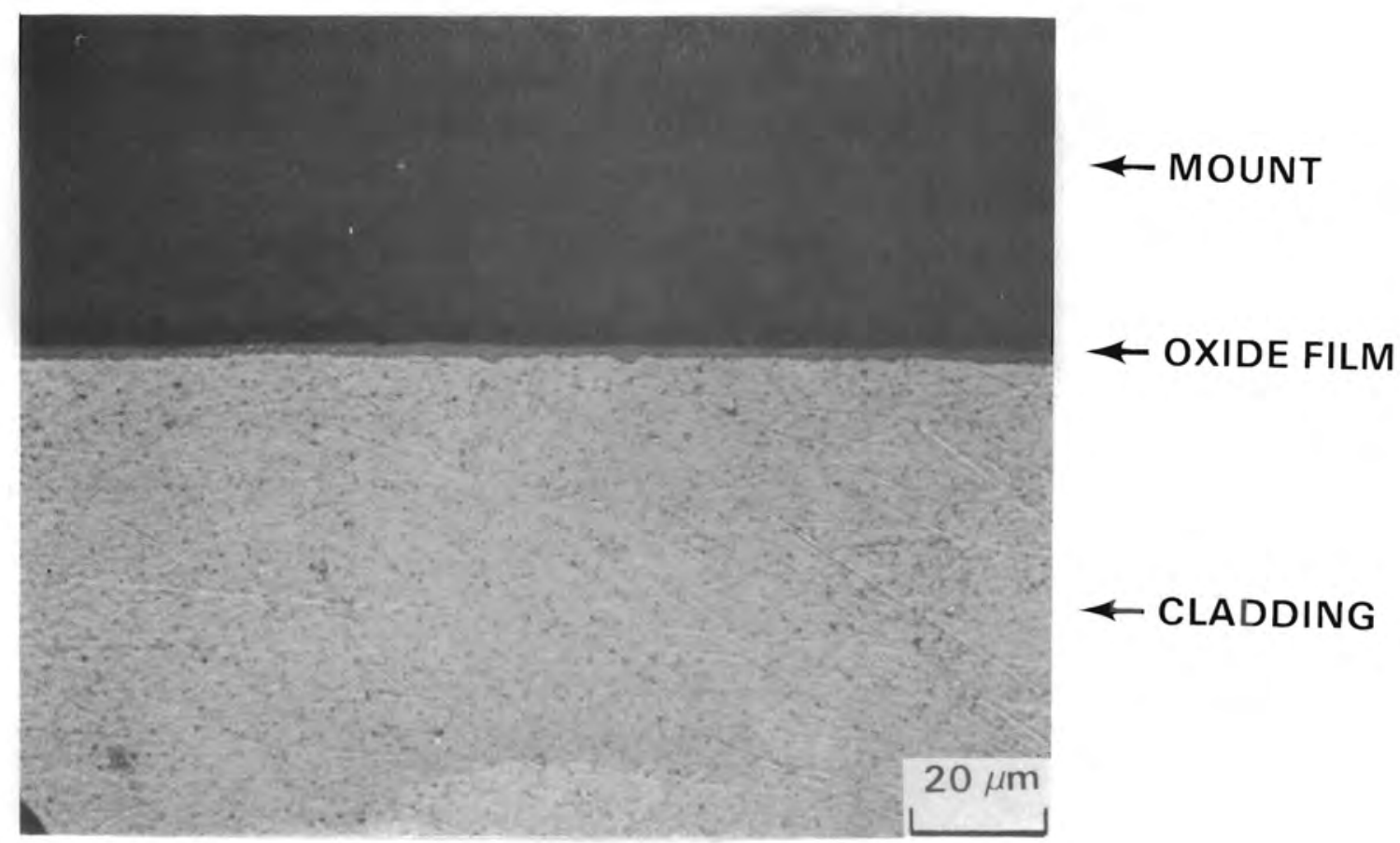

Neg. HC 50204

$$
\text { Rod } 5 \text { - Bundle } 0551
$$

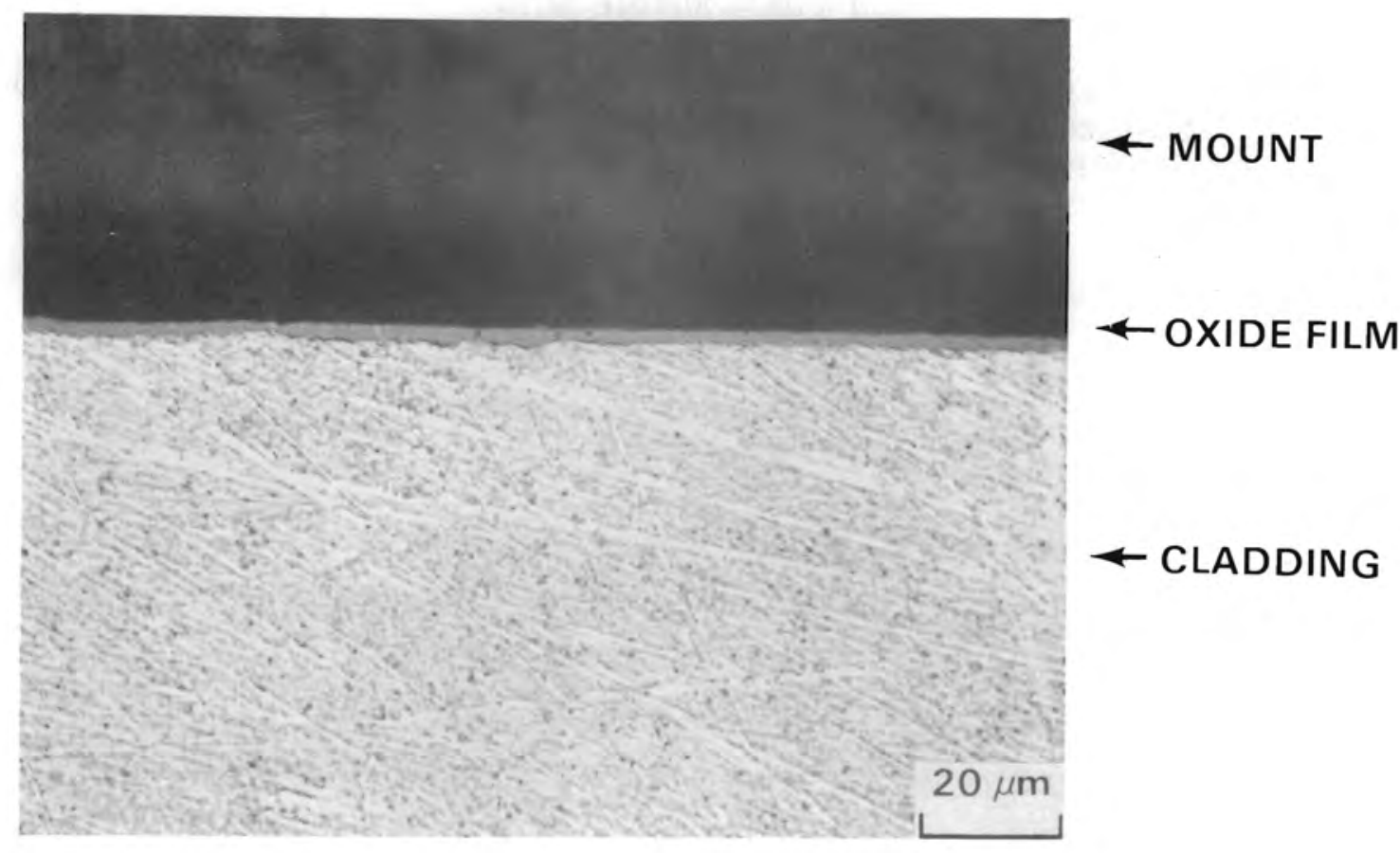

Neg. HC 50144

$$
\text { Rod } 120 \text { - Bundle } 0074
$$

FIGURE 14. Typical Oxide Films on External Cladding Surfaces After Extended Water Storage (as-polished) 


\section{CRUD DEPOSIT}

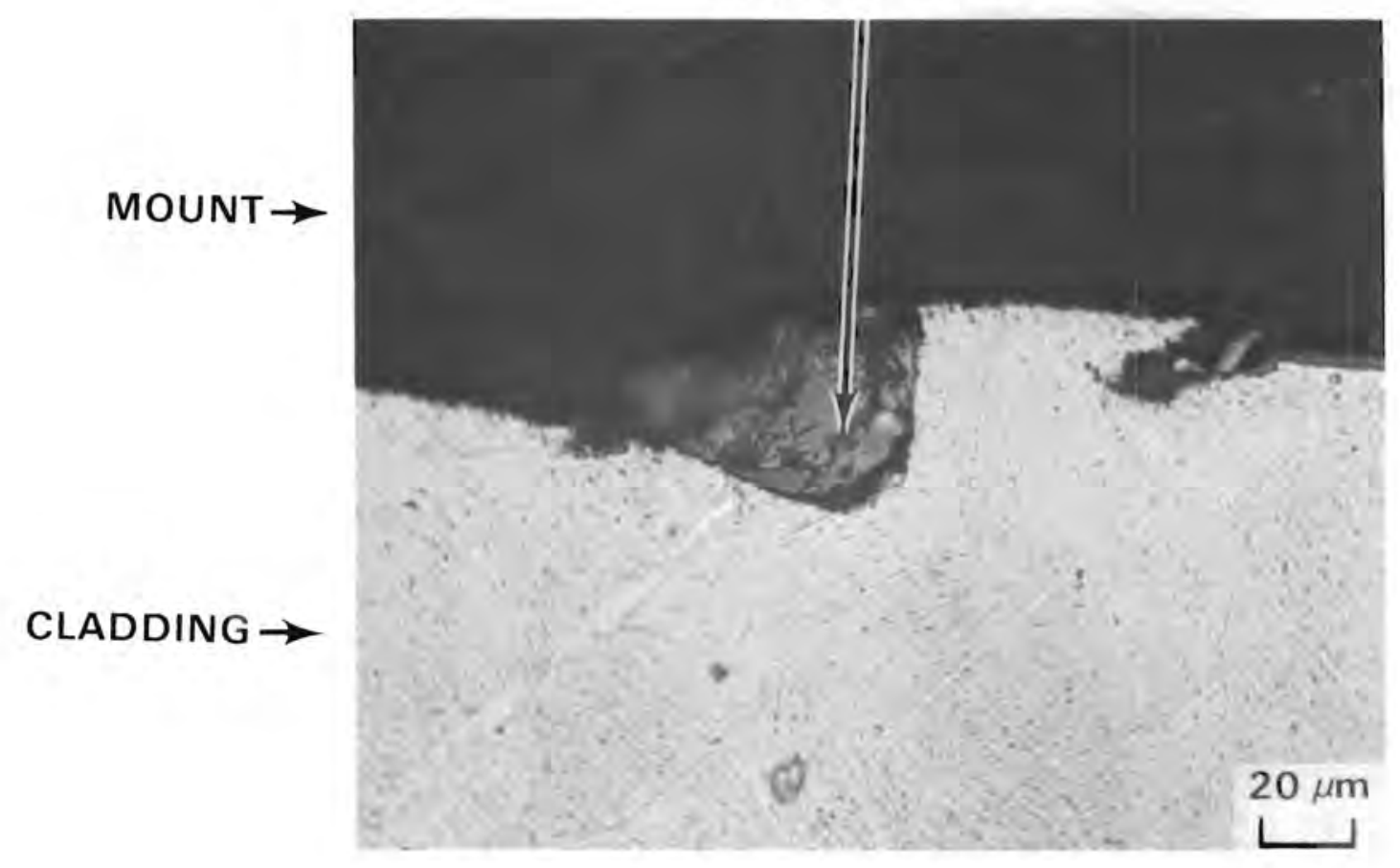

Neg. HC 50216

Rod 110 - Bundle 0074

FIGURE 15. Transverse Section Showing Superficial Defect on the External Surface of Rod 110 of Bundle 0074 (previously identified in Figure 9; as-polished)

With progressive grinding, the scratch became a shallow depression in the cladding and disappeared after about $3 \mathrm{~mm}$ had been ground away. No evidence of accelerated corrosion was observed near this region on any of the five surfaces examined.

Measurements of the oxide film thickness were made on at least one surface of each of the metallographic samples using a calibrated eyepiece. The oxide films ranged in thickness from 0.7 to $1.8 \mu \mathrm{m}$ for fuel rods from bundle 0551 and from 1.0 to $3.3 \mu \mathrm{m}$ for fuel rods from bundle 0074 . This includes $\sim 0.6 \mu \mathrm{m}$ of oxide formed by autoclaving the cladding prior to reactor exposure (Lynam 1963). The average values that were obtained from 10 to 20 individual random measurements are summarized in Table 7. 
TABLE 7. Comparison of Measured 0xide Film Thickness for Fuel Rods from Bundles 0551 and 0074

$\ddot{v}$

\begin{tabular}{|c|c|c|c|c|c|c|c|}
\hline Bundle & Rod & Samp le & $\underset{\mathrm{mm}}{\text { Location, (a) }}$ & $\begin{array}{c}\begin{array}{c}\text { Number } \\
\text { of }\end{array} \\
\text { Measurements } \\
\end{array}$ & $\begin{array}{c}\text { Mean 0xide } \\
\text { Thickness, } \\
\mu \mathrm{m} \\
\end{array}$ & $\begin{array}{l}\text { Standard } \\
\text { Deviation, } \\
\mu \mathrm{m}(1 \sigma) \\
\end{array}$ & $\begin{array}{c}\text { Range, } \\
\mu \mathrm{m}\end{array}$ \\
\hline \multirow[t]{2}{*}{0551} & 5 & $M-1$ & 5 & 10 & 1.4 & 0.3 & 1.0 to 1.8 \\
\hline & 5 & $M-2$ & 115 & 10 & 2.2 & 0.3 & 1.8 to 2.6 \\
\hline \multirow[t]{3}{*}{0551} & 13 & M-1 & 130 & 10 & 1.9 & 0.4 & 1.3 to 2.5 \\
\hline & 13 & $M-1$ & 130 & 20 & 1.4 & 0.6 & 0.7 to 2.3 \\
\hline & 13 & $M-2$ & 185 & 10 & 2.0 & 0.5 & 1.3 to 2.8 \\
\hline Average & & & & & 1.7 & & 0.7 to 2.8 \\
\hline \multirow[t]{2}{*}{0074} & 110 & $M-1$ & 95 & 10 & 2.3 & 0.1 & 2.1 to 2.5 \\
\hline & 110 & $M-2$ & 185 & 10 & 1.9 & 0.4 & 1.3 to 2.6 \\
\hline \multirow[t]{3}{*}{0074} & 120 & M-1 & 5 & 10 & 2.7 & 0.4 & 2.2 to 3.3 \\
\hline & 120 & $M-2$ & 120 & 10 & 2.2 & 0.6 & 1.3 to 3.3 \\
\hline & 120 & $M-2$ & 120 & 20 & $\underline{2.3}$ & 0.6 & 1.0 to 3.0 \\
\hline Average & & & & & 2.3 & & 1.0 to 3.3 \\
\hline
\end{tabular}

(a) Axial location measured from the bottom of the fuel rod. 
For fuel rods from bundle 0551, the mean oxide thickness from the four metallographic specimens ranged from 1.4 to $2.2 \mu \mathrm{m}$ with the overall average thickness being $1.7 \mu \mathrm{m}$. The sample-to-sample variation in oxide thickness is not significant as can be seen by comparing the two data sets from sample M-1 of rod 13. These data were taken from two polished surfaces that were separated by approximately $3 \mathrm{~mm}$; the difference in measured thickness $(0.5 \mathrm{\mu m})$ primarily reflects the difficulty in preparing samples with sharp interfaces (i.e., without edge rounding) that are essential for measuring these thin oxide films.

Bundle 0074 was exposed to the reactor environment 4 yr longer than bundle 0551; and, as expected, the oxide films were slightly thicker $(\sim 0.6 \mu \mathrm{m})$ on these fuel rods. Rubin and Lynam (1966) compared the oxide film thicknesses from the Shippingport fuel rods as a function of exposure during core 1 operation (1957 to 1964), and results presented in Figure 3 of their paper show the average cladding oxide film thickness was $1.8 \mu \mathrm{m}$ at the end of seed 1 and $2.4 \mathrm{um}$ following seed 4 . These values are in excellent agreement with the current results of $1.7 \mu \mathrm{m}$ for tundle 0551 and $2.3 \mu \mathrm{m}$ for bundle 0074 . Therefore, we conclude that no significant change in oxide thickness occurred during pool storage.

\section{Internal Cladding Surfaces}

Internal cladding surfaces of fuel rods from bundle 0551 showed no measurable oxide films or bonding between the fuel and $c$ ladding. Patches of oxide and fuel-cladding bonding were observed on the internal surfaces of fuel rods from bundle 0074, especially on rod 120. A typical bonded region in rod 120 is shown in Figure 16; the reaction layer is about $20 \mu \mathrm{m}$ thick. The condition of the internal cladding surfaces at comparable exposures after reactor discharge was not reported; thus, direct comparisons with the present work is not possible. However, patches of a gray phase at the internal surfaces in Shippingport fuel rods with less exposure have been reported (Lynam 1964) that are consistent with current observations.

The Shippingport fuel rods were among the first Zircaloy-clad $\mathrm{UO}_{2}$ fuel rods produced. The cladding fabrication technology that existed at the time is known to have produced defects on the internal cladding surfaces (Lynam et al. 1962; Henke 1966). The current examinations revealed some regions on 


\section{FUEL-CLADDING REACTION LAYER}

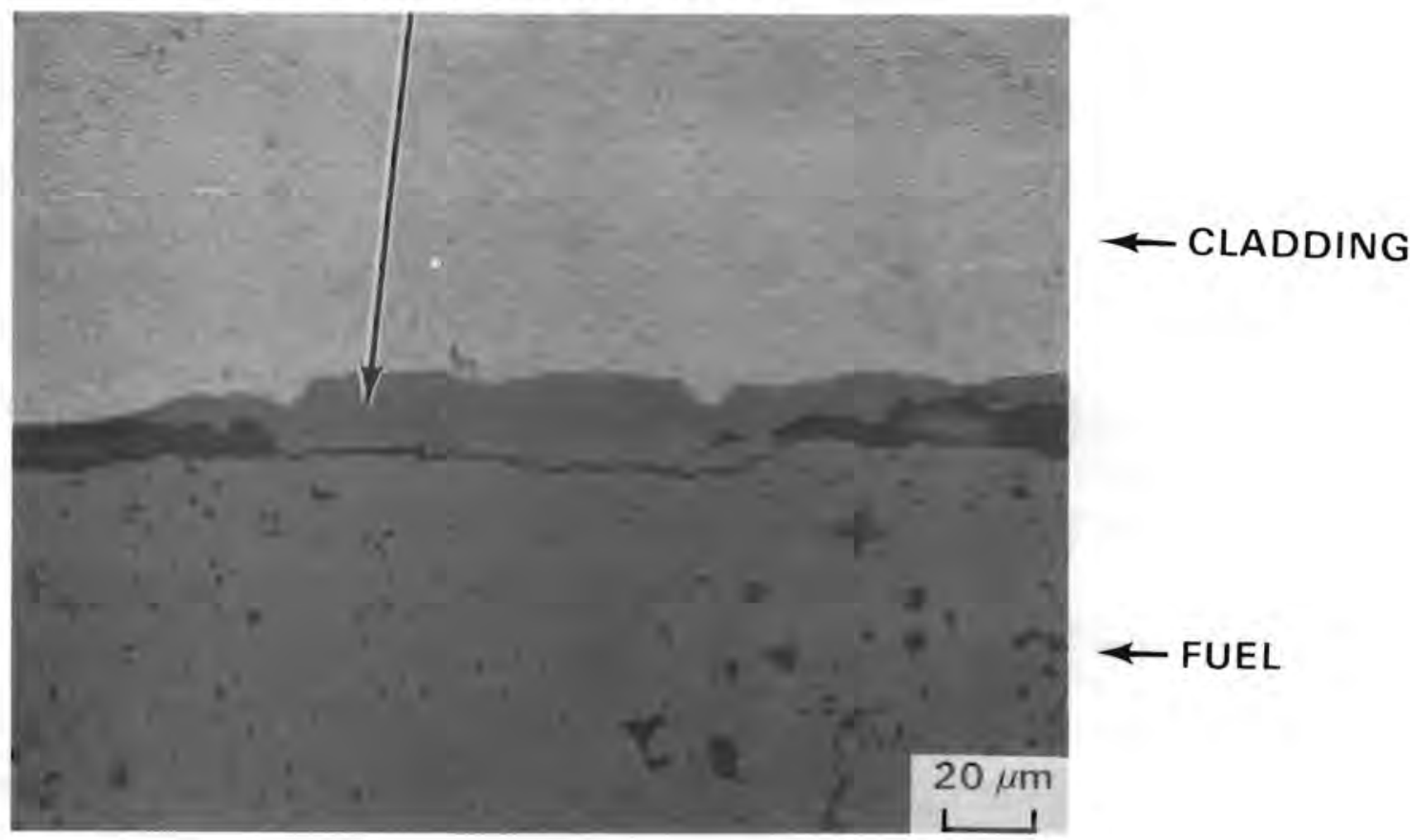

Neg. HC 50208

Rod 120 - Bundle 0074

FIGURE 16. Fuel-to-Cladding Bonding in Rod 120 of Bundle 0074 (as-polished)

the internal cladding surfaces of fuel rods from both bundles that were quite rough and contained some small ( $\sim 50-\mu \mathrm{m}$ deep) fabrication defects as shown in Figure 17. Extensive metallographic examinations were conducted on these defects, but no evidence of cladding deterioration caused by the internal fuel rod environment was observed.

In addition to these types of fabrication defects, a few microcrack-like defects were observed in rod 120 of bundle 0074 (see Figure 18). Although these defects were probably produced during fabrication of the cladding, their appearance is somewhat similar to microcracks formed by iodine stress corrosion cracking (SCC) (Rosenbaum 1980; Knorr and Pelloux 1981), which suggests they may have been formed by this mechanism.

For SCC to occur, the internal cladding surfaces must be subjected to tensile stresses and an adequate supply of the aggressive chemical species (iodine, cadmium, etc.) must be available to propagate the crack. During 


\section{ROUGH ID SURFACE}

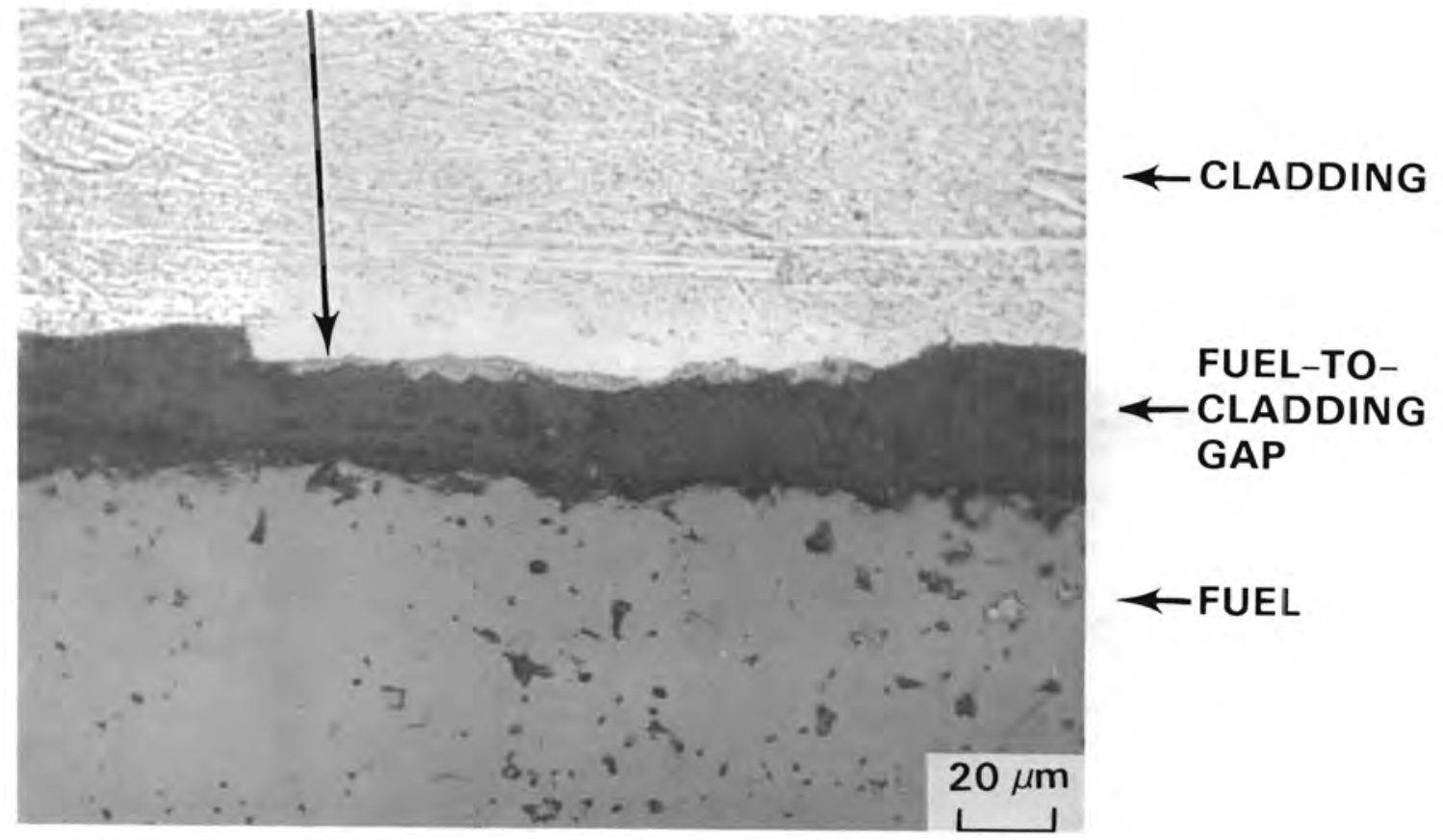

Neg. HC 50147

$$
\text { Rod } 120 \text { - Bundle } 0074
$$

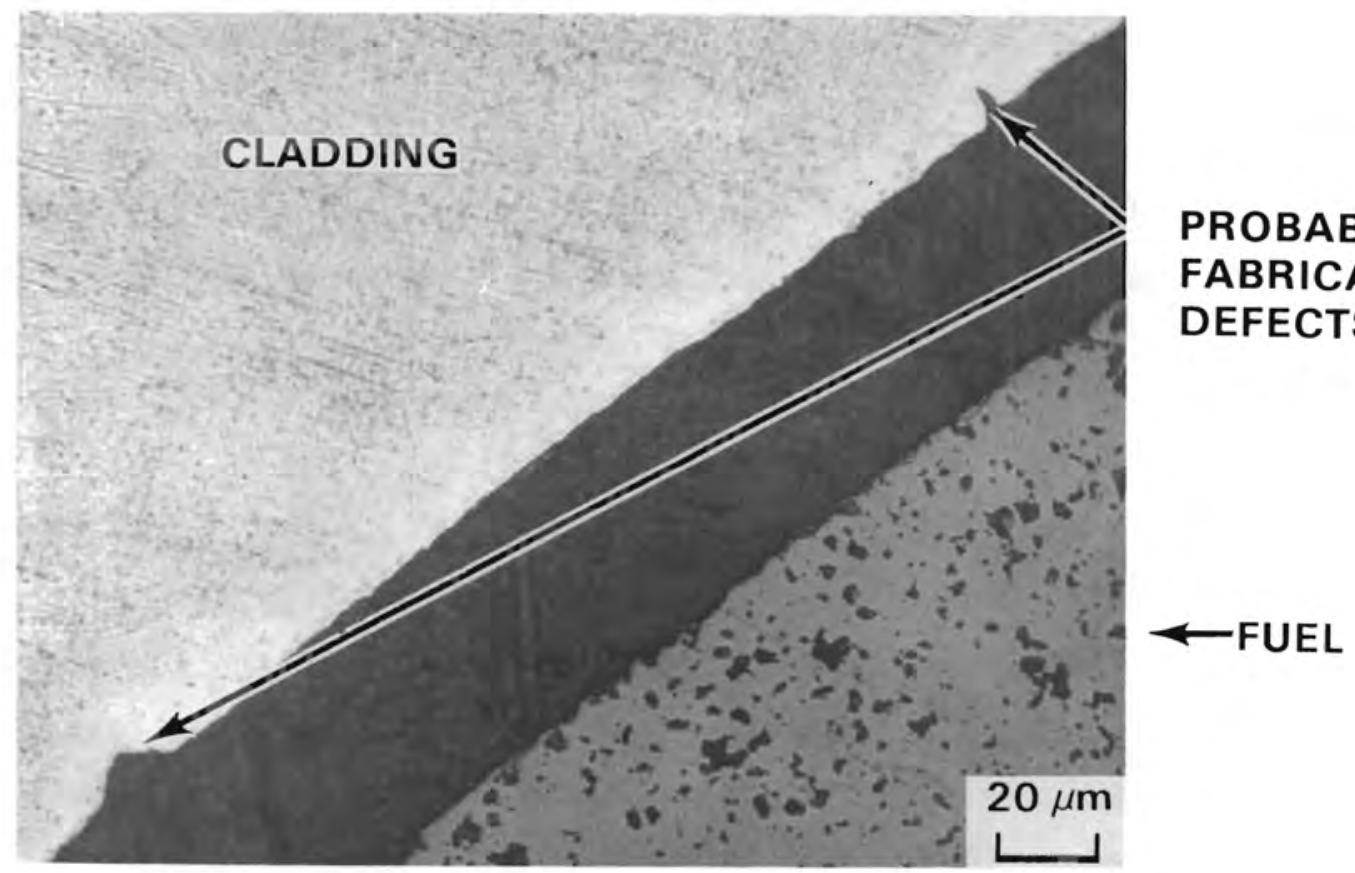

Neg. HC 50157

Rod 13 - Bundle 0551

FIGURE 17. Cladding Imperfections on the Internal Surfaces of Shippingport PWR Core 1 Fuel Rods (as-polished) 


\section{MICRO CRACK}

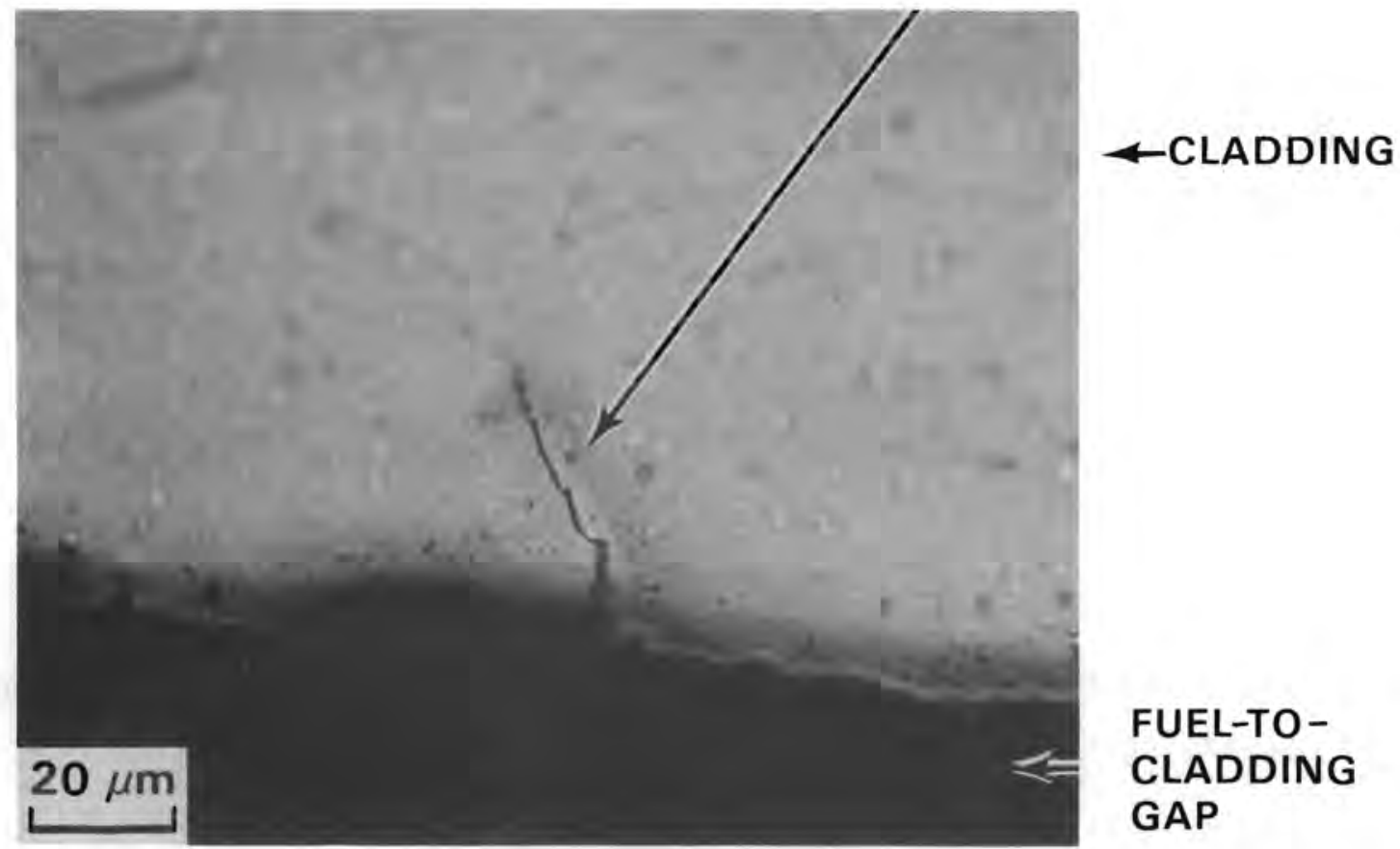

Neg. HC 50239

Rod 120 - Bundle 0074

FIGURE 18. Microcrack on Internal Surface of Rod 120 of Bundle 0074 that Could Have Been Produced During Cladding Fabrication or by Stress Corrosion Cracking During Reactor Operation (as-polished)

reactor operation, the necessary cladding stresses may be provided by the differential thermal expansion of the fuel; fission products released from the fuel may supply the necessary environmental effect. The fission product release fraction for the Shippingport fuel rods was less than $1 \%$; but at the high burnup level of rod 120, i.e., $3000 \mathrm{GJ} / \mathrm{kgU}(35,000 \mathrm{MWd} / \mathrm{MTU})$, fission products could conceivably have been available for SCC. The small fuel-tocladding gap in rod 120 caused by the bonding of the fuel and the cladding would tend to increase the cladding stresses during reactor operation; therefore, the microcracks observed in rod 120 could have been produced by SCC toward the end of the irradiation period. In either case, crack propagation was minimal. 
Although the microcracks could have formed during reactor exposure, the necessary conditions for SCC were not available during pool storage. Cladding stresses caused by fuel-cladding contact are minimal during storage because the fuel shrinks away from the cladding when cooled to ambient temperatures. The internal pressure in rod 120 was estimated from fuel rod puncture data to be only $0.2 \mathrm{MPa}(30 \mathrm{psi})$ and could produce tensile stresses at the internal cladding surfaces of about $0.7 \mathrm{MPa}(100 \mathrm{psi})$. This stress level is insignificant compared to the stresses required to form (Wood 1972) or propagate (Hunt, Wood, and Bain 1979) iodine SCCs in Zircaloy, which indicates that the microcracks observed in rod 120 could not have formed or extended during pool storage. Furthermore, fission product migration is severely limited at low temperatures, which precludes the supply of the aggressive species at the tip of a progressing crack.

\section{Hydrogen Content and Hydride Distribution}

Cladding samples for hydrogen analysis were taken from locations adjacent to the metallography samples (Figure 12). The fuel was removed from the samples, and the cladding rings were split longitudinally to provide duplicate samples from each location. Results from the hydrogen analysis are summarized in Table 8 along with previous results from Shippingport fuels after discharge.

The data in Table 8 show that no significant increase in the hydrogen content of the Zircaloy cladding occurred during pool storage. The average values for fuel rods from the two bundles are within the range of the average values from several fuel rods measured after discharge at the end of each seed refueling cycle. The data shown in Table 8 also indicate that there was no significant change in the cladding hydrogen content with reactor exposure, which is consistent with current measurements. Furthermore, the current measurements are well within the range of individual measurements ( 38 to $133 \mathrm{ppm}$ ) obtained on Shippingport fuel rods after discharge from the reactor. The large range in the measurements reflects rod-to-rod differences in hydrogen content as well as axial variations and the difficulties in measuring small quantities of hydrogen in the cladding.

The metallographic examinations also indicated that no measurable changes in hydride distribution had occurred during pool storage. The hydride needles 
TABLE 8. Summary of the Measured Hydrogen Content in the Shippingport Fuel Rod Cladding

\begin{tabular}{lrcc} 
Bundle & Rod & Sample & Hydrogen Content, ppm \\
\cline { 3 - 4 } 0551 & 5 & $H-1$ & 53,54 \\
0551 & 5 & $H-2$ & 83,84 \\
0551 & 13 & $H-1$ & 86,80 \\
0551 & 13 & $H-2$ & 74,75 \\
Average & & & $73 \pm 13(10)$ \\
0074 & 110 & $H-1$ & 88,72 \\
0074 & 110 & $H-2$ & 58,58 \\
0074 & 120 & $H-1$ & 60,62 \\
0074 & 120 & $H-2$ & 88,79 \\
Aver age & & & $71 \pm 13(10)$ \\
Prior Work (a) & & & 62 \\
End of first seed & & & 53 \\
End of second seed & & & 69 \\
End of third seed & & &
\end{tabular}

(a) Rubin and Lynam 1966.

were uniformly distributed through the cladding (see Figure 19), and their appearance was very similar to those shown in previous reports. (a) No distinct differences in the hydride morphologies or distributions on the transverse sections were observed between fuel rods from the two bundles.

As stated previously, the iron lifting cable that was attached to bundle 0074 provided an opportunity to examine the bottom end of rod 110 for possible accelerated corrosion or hydrogen pickup caused by the galvanic couple between the cable and the Zircaloy tube sheet. Results from the hydrogen analyses of the three sections shown previously in Figure 13 are given in Table 9 , and a photomicrograph from the contact area is shown in Figure 20.

(a) Rubin 1961a; Lynam 1961; Lynam 1963; Lynam 1964; Rubin and Lynam 1966. 


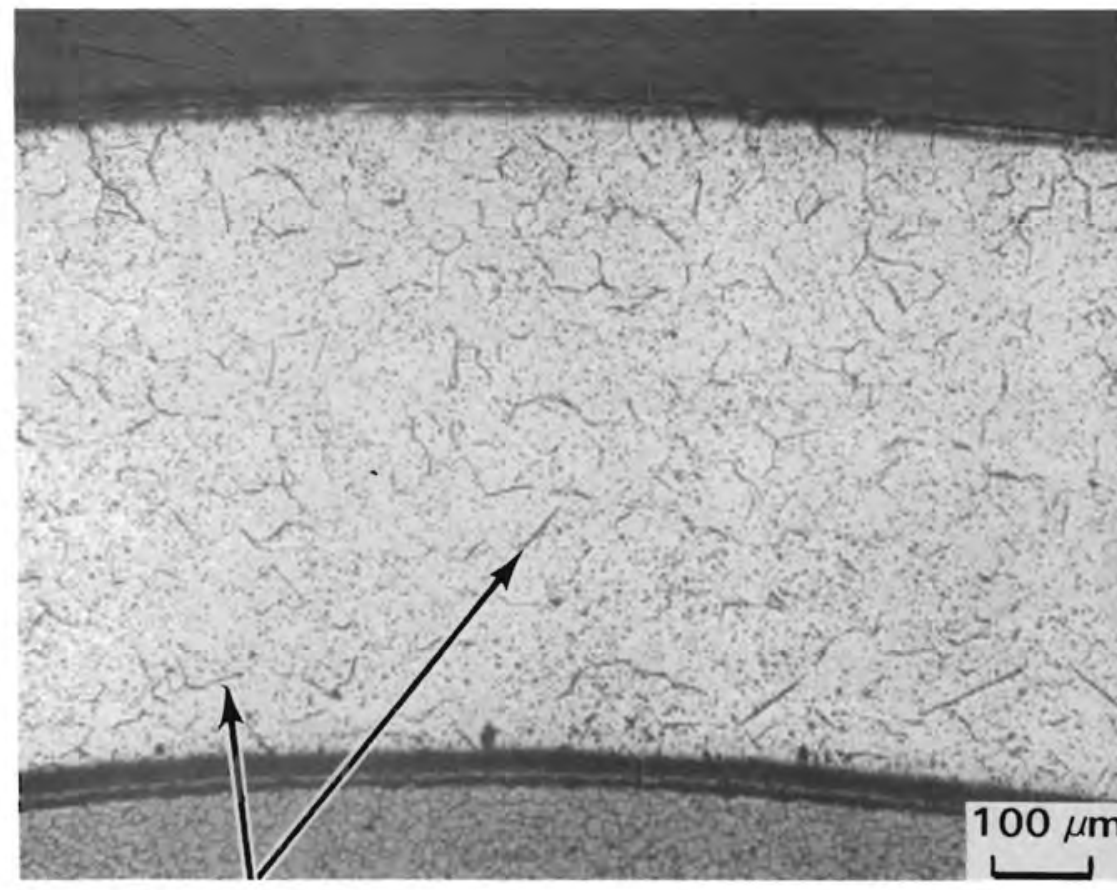

$\leftarrow$ MOUNT

HYDRIDE NEEDLES

Neg. HC 50249

Rod 4 - Bundle 0051

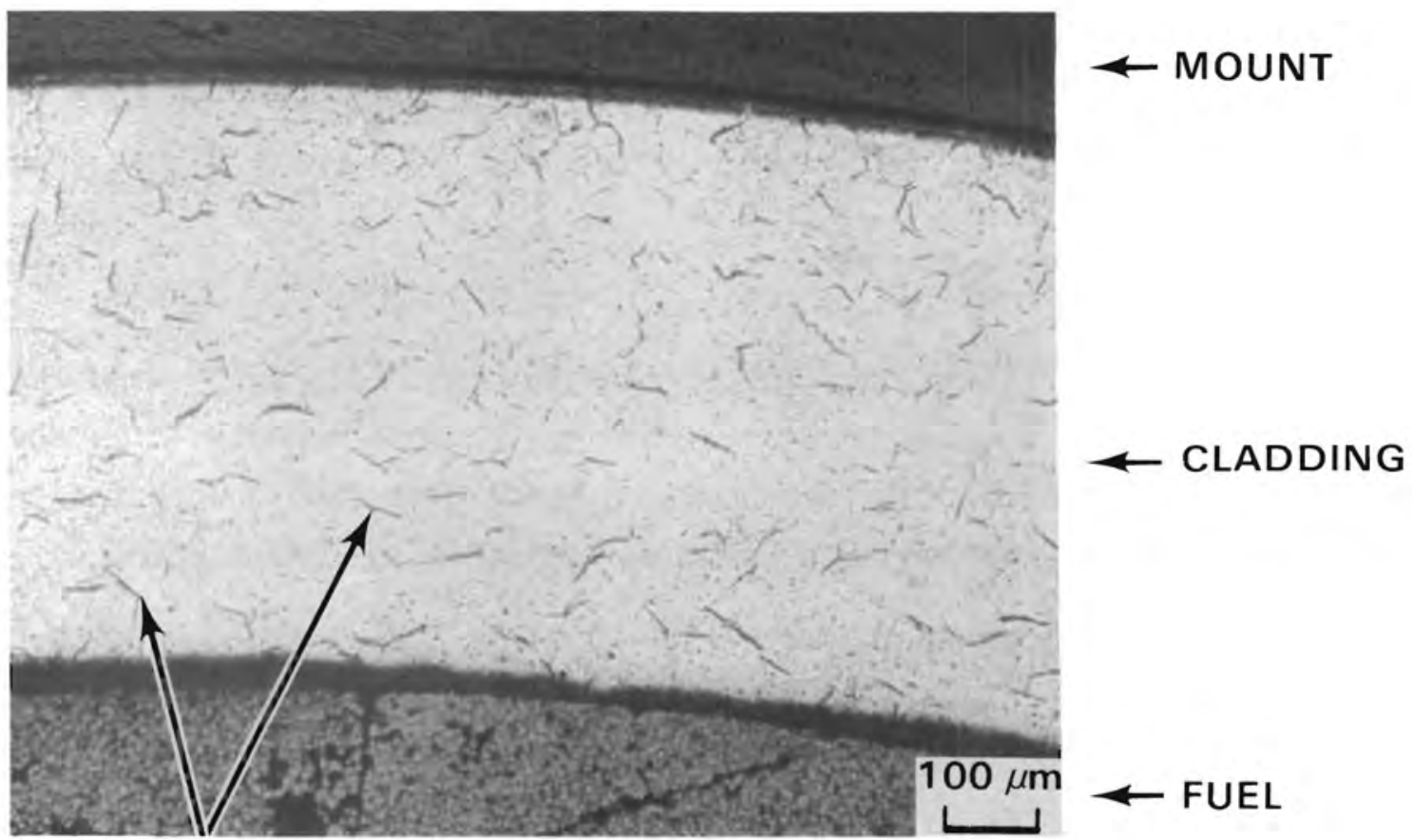

HYDRIDE NEEDLES

Neg. HC 50253

$$
\text { Rod } 110 \text { - Bundle } 0051
$$

FIGURE 19. Typical Hydride Distributions in Shippingport PWR Core 1 Fuel Rod Cladding After Extended Water Storage (etched) 
TABLE 9. Hydrogen Content of Tube Sheet Samples from the Bottom End of Rod 110 of Bundle 0074

\begin{tabular}{|c|c|c|}
\hline Location $(a)$ & Sample & $\begin{array}{c}\text { Hydrogen } \\
\text { Content, ppm }\end{array}$ \\
\hline Contact Area & $110 \mathrm{H}-3$ & 73 \\
\hline Center & $110 \mathrm{H}-4$ & 70 \\
\hline Outside & $110 \mathrm{H}-5$ & 71 \\
\hline
\end{tabular}

(a) As shown in Figure 13.

No evidence of accelerated corrosion or hydrogen pickup was detected by the examinations. The hydrogen content of the three specimens varied by only $3 \mathrm{ppm}$, which is well within the estimated $\pm 10 \%$ uncertainty in the experimental measurement. Results from metallographic examinations supported the hydrogen analyses in that no significant differences in hydride distributions were seen

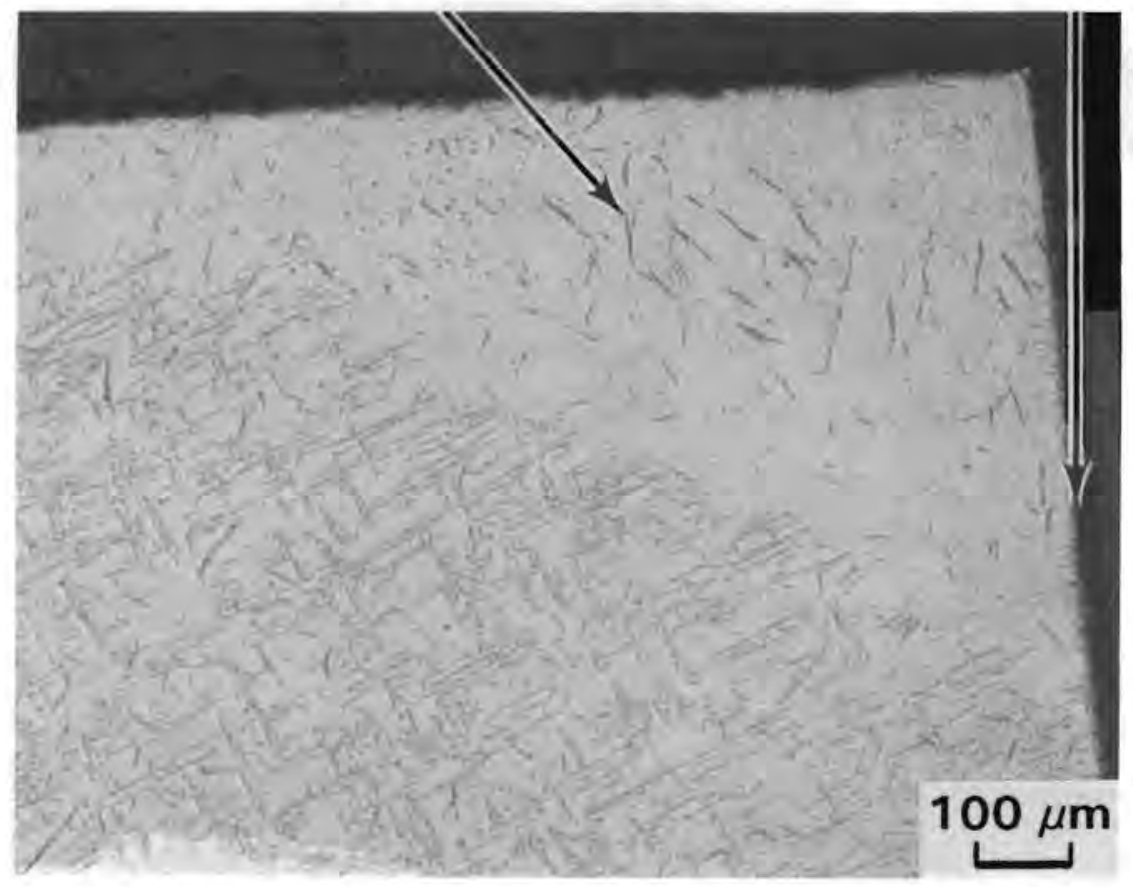

Neg. HC 50278

$$
\text { Rod } 110 \text { - Bundle } 0074
$$

FIGURE 20. Contact Area Between the Steel Lifting Cable and the Bottom End of Rod 110 of Bundle 0074 (note that hydride needles are not concentrated at the contact surface; etched) 
in the contact area. In addition, there were no indications of accelerated corrosion of the Zircaloy near the contact area.

Weld Areas

Metallographic examination of the longitudinal sections through the bottom end caps of rod 5 of bundle 0551 and rod 120 of bundle 0074 revealed no evidence of cladding deterioration near the welds between the end caps and cladding. A Widmanstatten-type structure, typical of beta-quenched Zircaloy, existed in the end cap regions; and the hydride needles were uniformly distributed in the cladding and end cap material. The welds in both fuel rods were sound, but some evidence of incomplete penetration was observed in rod 5 of bundle 0551. Photomicrographs illustrating these features are shown in Figure 21 .

The microstructures and hydride distributions observed during the current examinations appear to be very similar to those shown in previous reports of Shippingport fuel rods after reactor discharge (Rubin 1961a; Lynam 1961; Lynam 1963; Lynam 1964). Incomplete weld penetration was also noted previously (Lynam 1964); and, thus, the current results indicate that no changes in microstructure, hydride distributions, or characteristics of the welds have occurred during pool storage.

External and internal surfaces in the end cap regions showed similar characteristics to the surfaces in the interior of the fuel rods. A uniform oxide film covered the external surfaces; there were no indications of localized attack. The oxide film on rod 120 of bundle 0074 was slightly thicker $(0.4 \mathrm{\mu m})$ than the average thickness on fuel rods from this bundle. However, for rods from bundle 0551 the oxide film at the end cap region was $0.3 \mu \mathrm{m}$ less than the average for this bundle although no significance should be given to these differences. The internal surfaces of rod 5 of bundle 0551 were relatively featureless with no oxide being evident. A $\sim 10-\mu \mathrm{m}$ thick oxide film was seen at the end cap-fuel interface in rod 120 of bundle 0074, which is consistent with the results from the transverse section of this fuel rod. No oxide films were observed in the weld crevices of either rod nor were microcracks or other cladding defects detected in the heat-affected zone of the cladding. 


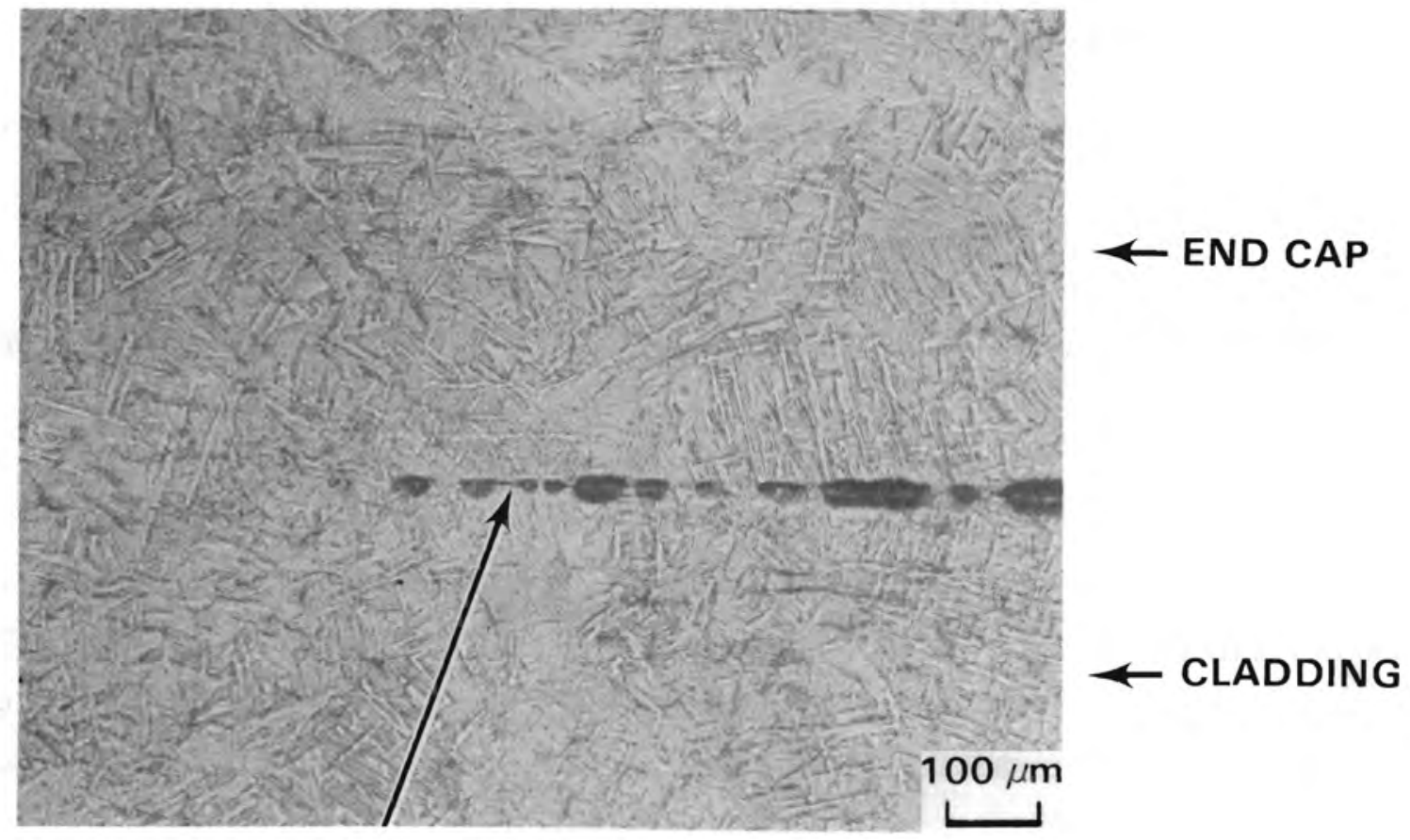

INCOMPLETE WELD PENETRATION

Neg. HC 50266

Rod 5 - Bundle 0075

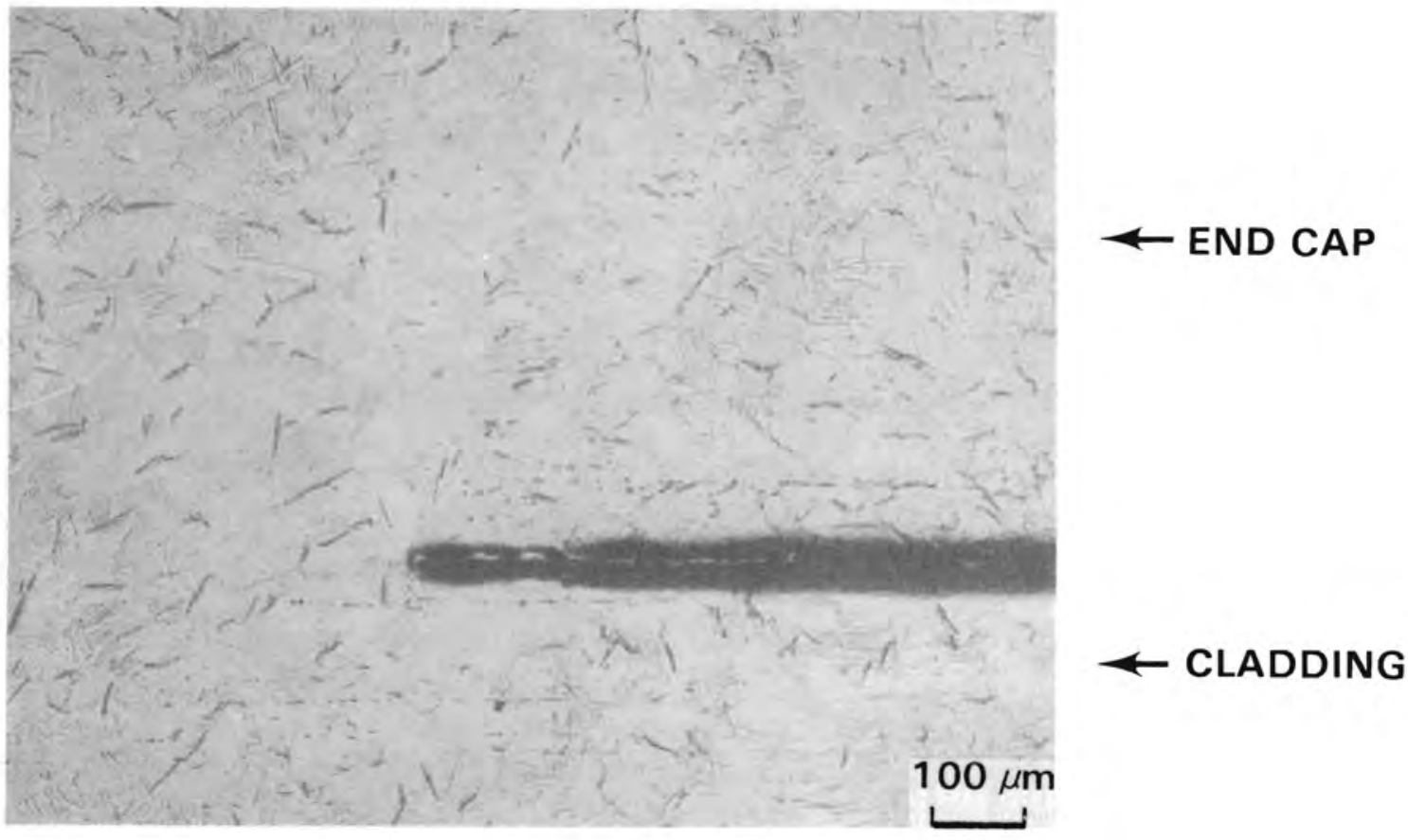

Neg. HC 50265

Rod 120 - Bundle 0074

FIGURE 21. End Cap Welds from Shippingport Fuel Rods After Extended Water Storage (note Widmanstatten structure and uniform hydride distribution; etched) 
Therefore, the metallographic examinations provided no evidence of cladding degradation at welds following extended pool storage.

$\underline{\mathrm{UO}} 2$ Fuel

Metallographic examinations of the $\mathrm{UO}_{2}$ fuel were conducted on six transverse sections (three from each bundle); no evidence of fuel deterioration was detected. The $\mathrm{UO}_{2}$ fuel showed the typical radial cracking that is caused by differential thermal expansion during reactor operation. As expected, some variations in fuel grain size and porosity existed between different fuel pellets and radial locations; but the typical microstructures were similar for fuel rods from both bundles (see Figure 22). Typical fuel microstructures are also very similar to those reported for previous Shippingport fuel rods after reactor discharge.

Burnup Analysis

Burnup analysis samples were taken from near the centers of rod 13 of bundle 0551 and rod 110 of bundle 0074. The axial gamma scans show a relatively flat profile along the rod axis; and, therefore, the burnups derived from the small samples are representative of the entire fuel rod.

The results of the analyses give a burnup of $420 \mathrm{GJ} / \mathrm{kgU}$ ( $4900 \mathrm{MWd} / \mathrm{MTU}$ ) for rod 13 of bundle 0551 and $3100 \mathrm{GJ} / \mathrm{kgU}(36,000 \mathrm{MWd} / \mathrm{MTU})$ for rod 110 of bundle 0074. The measured burnup for rod 13 agrees very well with the burnups measured on fuel rods from bundle 0551 during the hot cell examinations conducted in 1960 (Sphar 1962). Burnup analyses were not conducted on fuel rods after being discharged from the reactor in 1964, but the current experimental value for rod 110 is about $25 \%$ higher than estimated by computer code calculations (Henke 1966). This apparent discrepancy is most likely associated with the uncertainties in the computer code calculations where assumed values for axial peaking factors, end cap peaking factors, and local hot channel factors were used in the computations. Differences between calculated and measured burnups of up to $14 \%$ were reported at the end of the first seed (Sphar 1962), and the uncertainties in the calculated values will increase with burnup because of the increasing contribution from plutonium fission. Consequently, the 25\% difference between calculated and measured burnups for rod 110 of bundle 0074 is not unreasonable. 


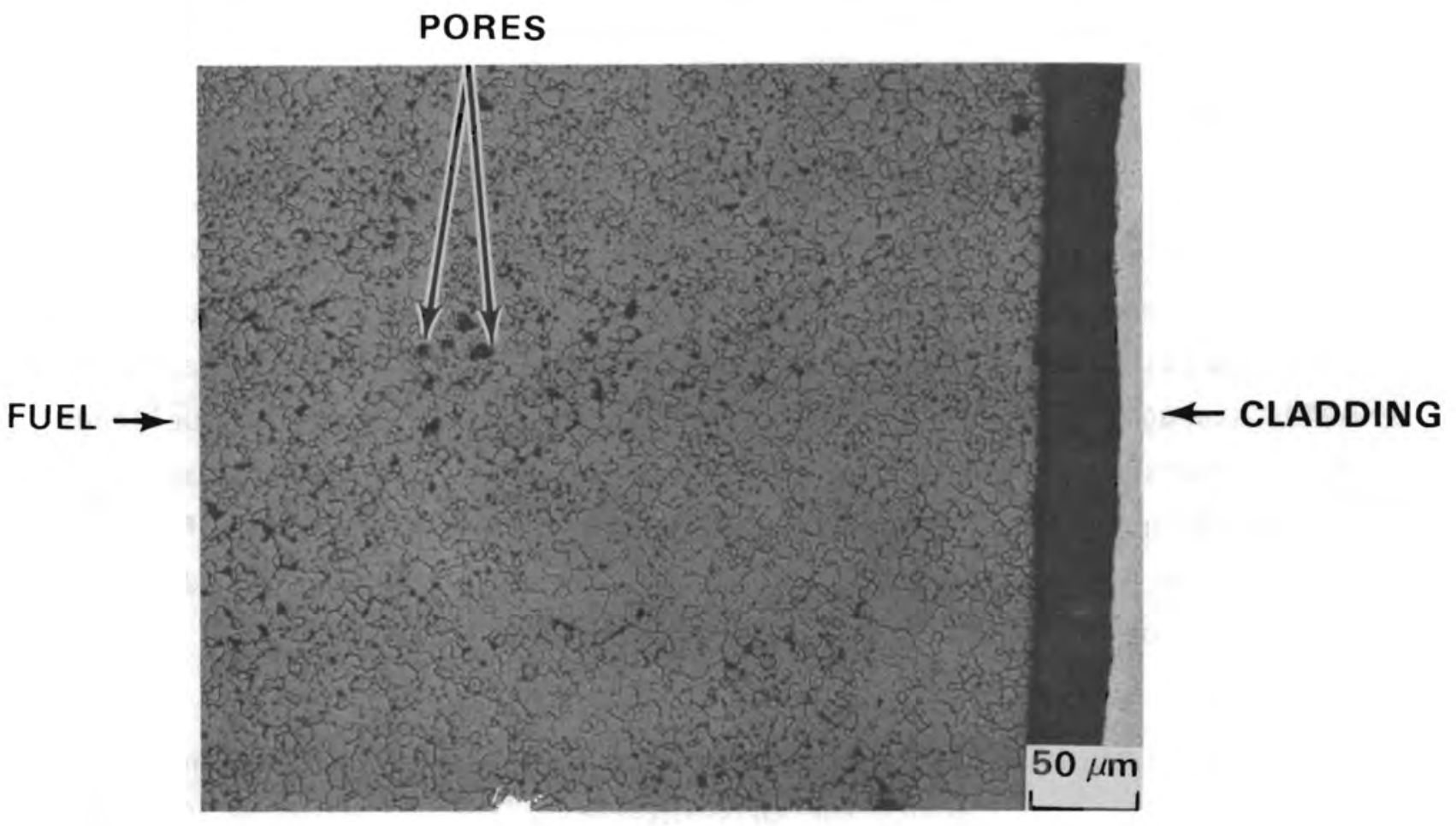

Neg. HC 50229

PORES Rod 13 - Bundle 0551

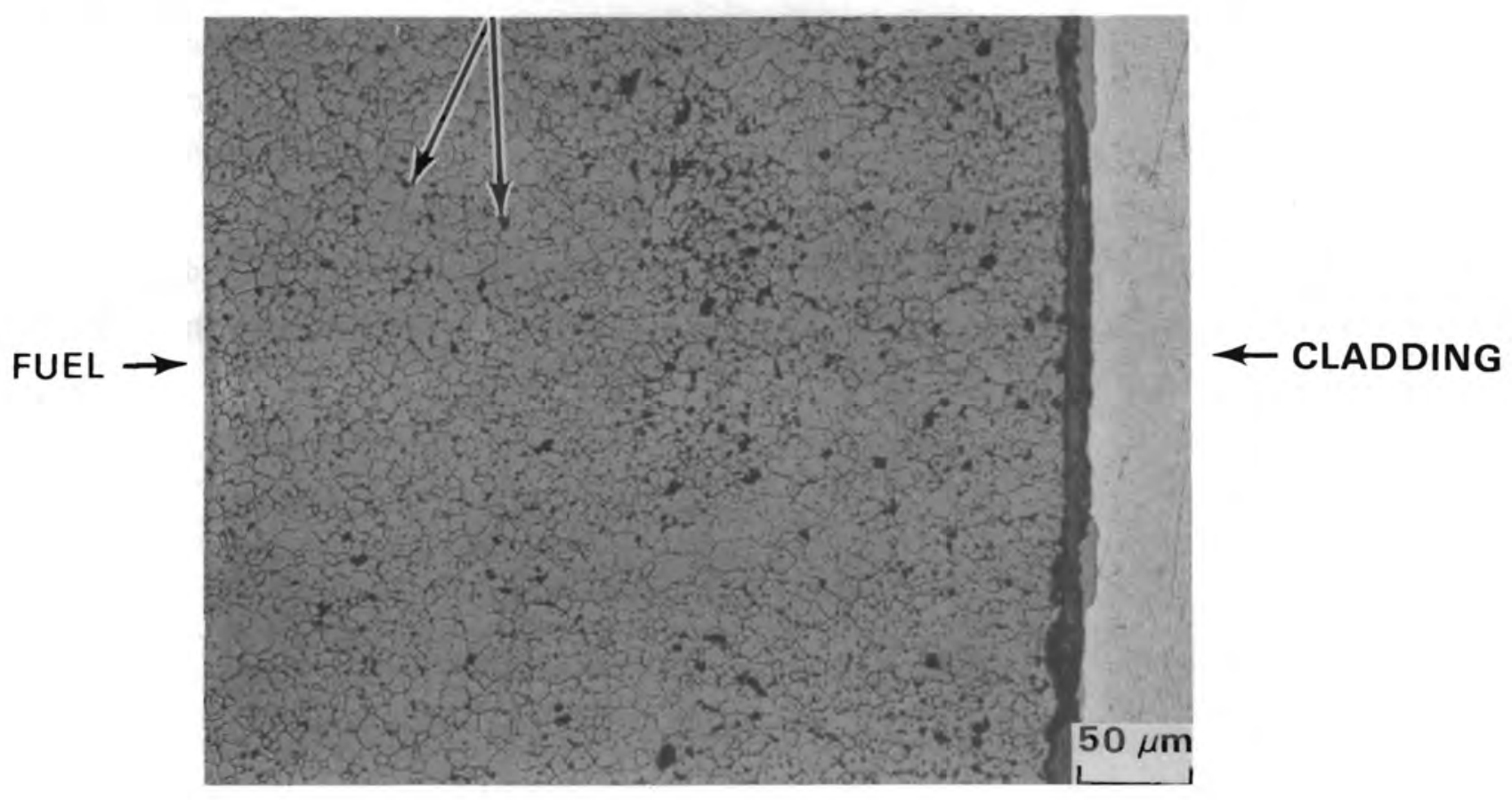

Neg. HC 50232

$$
\text { Rod } 110 \text { - Bundle } 0074
$$

FIGURE 22. Typical Microstructures of Shippingport Fuel After Extended Water Storage (etched) 
Eight fuel rods from two bundles of Shippingport PWR Core 1 blanket fuel have undergone extensive metallurgical examinations to assess the possible effects of extended pool storage on the integrity of Zircaloy-clad fuel. None of the examinations produced evidence of cladding degradation that was caused by water storage. No significant changes in the appearance of the fuel rods, cladding dimensions or mechanical properties, fission gas release fractions, hydrogen content or distribution in the cladding, or the thickness of the external oxide films were found after extended water storage. In addition, localized corrosion or hydriding was not detected.

Water was detected in some of the samples collected for fission gas analysis but was attributable to leakage into the sample vials rather than defective fuel rods. Additional support for this interpretation was obtained from the burst tests where the bursting pressures and appearance of the ruptured fuel rods were independent of the water content in the gas samples.

Small cladding defects were observed at a few locations on internal cladding surfaces. The defects were probably formed during fabrication of the cladding, based on evidence from earlier literature (Lynam et al. 1962). Some microcracks may have possibly formed by SCC during reactor operation in the highly irradiated rods from bundle 0074 . However, the necessary conditions for SCC did not exist during pool storage, which strongly suggests that the microcracks did not form or extend during this period. 
The metallurgical examinations of the Shippingport fuel rods after more than 20 and $16 \mathrm{yr}$ of pool storage agree with past experience and theoretical assessments. The current Shippingport examinations are especially significant because of the extensive data base that is available from examinations of similar fuel after reactor discharge and their long storage times, i.e., over $20 \mathrm{yr}$ for bundle 0551 and $16 \mathrm{yr}$ for bundle 0074. The remainder of this section discusses the current results with regard to 1) previous Shippingport fuel examinations, 2) specific cladding degradation mechanisms, and 3) other spent fuel examinations.

\section{COMPARISON WITH PREVIOUS SHIPPINGPORT EXAMINATIONS}

The relationship between the current and previous metallurgical examinations of the Shippingport blanket fuel rods was shown in Figure 3 . Examinations were performed soon after each of the three seed replacements and following discharge of the first core in $1964 .{ }^{\text {(a) To additional examinations }}$ were conducted on selected fuel rod bundles from the first core loading that reached high exposures in the reactor through the MELBA test program ( $H i l$ iner 1974; Hillner 1980). These data indicate how reactor exposure affects the corrosion of Zircaloy; the effects of water storage are seen by comparing the 1980 examination results reported here to those obtained after the first and fourth seeds.

Results from present and past examinations of the Shippingport PWR Core 1 blanket fuel rods are compared in Table 10. These comparisons suggest that no significant changes have occurred in cladding dimensions, bursting pressures, fission gas release, hydrogen content of the cladding, or in the thickness of the external oxide film. The currently determined values for each of these measurements are well within the range of the individual measurements made after reactor discharge and thereby indicate that neither the Zircaloy-2 cladding nor the $\mathrm{UO}_{2}$ fuel has significantly degraded after nearly $21 \mathrm{yr}$ of pool storage.

(a) Lynam 1963; Lynam 1964; Henke 1966; Rubin and Lynam 1966; Larson 1960; Rubin 1961(a); Rubin 1961(b); Sphar 1962; Lynam 1961; Lynam 1962. 
TABLE 10. Comparison of Results from Hot Cell Examinations of Zircaloy-Clad Shippingport PWR Core 1 Blanket Fuel Rods

\begin{tabular}{|c|c|c|c|c|c|c|c|c|c|}
\hline Examination & $\begin{array}{c}\text { Year } \\
\text { Discharged } \\
\text { from }(\mathrm{a}) \\
\text { Reactor } \\
\end{array}$ & $\begin{array}{c}\text { Pool } \\
\text { Storage, } \\
y r\end{array}$ & $\begin{array}{c}\text { Fuel Rod } \\
\text { Diameter, } \\
\text { mm }\end{array}$ & & $\begin{array}{l}\text { ximum } \\
\text { ality, } \\
\text { mm }\end{array}$ & $\begin{array}{c}\text { Burst } \\
\text { Pressure, } \\
\text { MPa }\end{array}$ & $\begin{array}{c}\text { Fission } \\
\text { Gas } \\
\text { Release, } \\
\% \\
\end{array}$ & $\begin{array}{l}\text { Hydrogen } \\
\text { Content of } \\
\text { Cladding, } \\
\text { ppm } \\
\end{array}$ & $\begin{array}{c}\text { Oxide Film } \\
\text { Thickness, } \\
\mu \mathrm{m}\end{array}$ \\
\hline $\begin{array}{l}\text { Erd of First } \\
\text { Seed (b) }\end{array}$ & 1959 & -- & 10.41 to 10.64 & 0.02 & to 0.09 & 91 to 102 & 0.2 to 0.7 & 49 to 101 & 1.3 to 2.5 \\
\hline $\begin{array}{l}\text { Present Work } \\
\text { (Bundle 0551) }\end{array}$ & 1959 & $\sim 21$ & 10.44 and 10.44 & 0.08 & and 0.10 & 102 and 105 & 0.2 to 0.5 & 53 to 133 & 0.7 to 2.8 \\
\hline End of Second Seed & 1961 & -- & 10.43 and 10.47 & 0.04 & to 0.12 & 91 to 114 & 0.2 to 0.6 & 38 to 63 & 0.6 to 1.3 \\
\hline End of Third Seed & 1962 & -- & 10.33 and $10.39(c)$ & 0.03 & and 0.06 & -- & 0.8 and 0.9 & 57 to 73 & 1.2 to 2.5 \\
\hline Enf of Fourth Seed & 1964 & -- & -- & & -- & 98 and 102 & - & 52 to 93 & 1.8 to 3.3 \\
\hline $\begin{array}{l}\text { Present Work } \\
\text { (Bundle 0074) }\end{array}$ & 1964 & 16 & 10.42 and 10.42 & 0.10 & and 0.15 & 99 and 103 & 0.3 and 0.5 & 58 to 89 & 1.0 to 3.3 \\
\hline ME $: B A$ I $(d)$ & 1969 & - & -- & & -- & -- & -- & 108 to 199 & 7.4 to $11.9(\mathrm{e})$ \\
\hline ME_BA II & 1974 & 4 & -- & & -- & -- & -- & 188 to 454 & 7.8 to $19.6(\mathrm{e})$ \\
\hline
\end{tabular}

(a) Core 1 started operation in December 1957.

(b) The 1959 examination involved fuel rods from bundle 0551 ; roos from the same bundle were examined in 1980.

(c) Small diameters attributed to final pickling operation (Lynam 1964).

(d) $M E L B A=$ Multipurpose Extended Life Blanket Assembly.

(e) Averaged values from metallographic sections. 
In addition, extensive visual examinations of external cladding surfaces, nondestructive tests, and metallographic examinations of the cladding did not identify any regions of localized attack due to the water storage environment. The appearance of the external surfaces and the microstructure of the cladding were the same as described in the early 1960s when similar fuel rods were examined after reactor discharge. The bright metallic appearance of the cut surfaces on the tube sheets from fuel rods of bundle 0551 after more than 20 yr in underwater storage attest to the excellent corrosion resistance of Zircaloy-2.

The fine microcracks (Figure 18) that were occasionally observed on the internal surfaces of rod 120 of bundle 0074 represent the on $1 y$ microstructura 1 feature observed during the current examinations that had not specifically been identified and reported previously. Internal cladding fabrication defects were known to exist in some of the Shippingport cladding; Lynam et al. (1962) reported that the majority of the internal defects were less than $125 \mathrm{\mu m}$ deep in cladding containing up to 0.37 defects $/ \mathrm{mm}^{2}\left(240\right.$ defects $/$ in. $\left.{ }^{2}\right)$. Photomicrographs from transverse sections showing the nature of the shallow defects were not presented by Lynam et al., but it is very likely the microcracks observed in the present examinations were formed during fabrication of the cladding.

An alternate explanation is that these fine microcracks were formed by SCC whereby fission products released from the fuel in conjunction with cladding stresses produced by differential thermal expansion of fuel and cladding results in premature failure of the Zircaloy cladding (Roberts et al. 1977). Although the fission product release fraction from the Shippingport fuel was low $(<1 \%)$, the high burnup--3100 GJ/kgU $(36,000 \mathrm{MWd} / \mathrm{MTU})-$-and the small diametral gap in rod 120 could have provided the necessary conditions for SCC of the cladding during reactor operation. During pool storage, however, cladding stresses are minimal and the mobility of fission products is decreased at low temperatures (298K), which virtually eliminates the possibility that these small cracks could have formed or extended during pool storage.

In addition to providing the data necessary to obtain a direct assessment of the effects of extended pool storage on fuel rod integrity, the extensive Shippingport data base allows the in-pile corrosion characteristics of Zircaloy-2 clad fuel to be determined (Hillner 1980). This is important to 
spent fuel storage technology because it represents an upper limit to the cladding degradation that will occur in a water environment.

The results of the MELBA II examinations are especially significant in this regard because these fuel rods resided in the reactor for $17 \mathrm{yr}$. For more than $12 \mathrm{yr}$ the coolant temperature was above $473 \mathrm{~K}\left(200^{\circ} \mathrm{C}\right)$ and corrosion was accelerated by the irradiation environment (Hillner 1980). Even under these severe exposure conditions, less than $3 \%$ of the Zircaloy-2 cladding had oxidized uniformly and localized attack of the cladding was not observed. The cladding had picked up a considerable amount of hydrogen, but none of the fuel rods failed during reactor operation where extensive thermal and stress cycling occurs. The conditions that exist in a spent fuel storage pool are much less severe than in the reactor (Johnson 1979); thus, the excellent behavior of the fuel rods in the MELBA II tests adds further important evidence that extended water storage of fuel rods with Zircaloy cladding is a safe and viable option for spent fuel management.

POTENTIAL DEGRADATION MECHANISMS

Prior spent fuel integrity studies (a) have assessed potential cladding degradation mechanisms that must be considered in spent fuel storage regimes. Table 11 summarizes the mechanisms and how they were assessed in the current hot cell examinations. Visual inspection, metallography, and hydrogen analyses were used primarily to assess the various mechanisms; the results of these examinations have been presented previously. None of the mechanisms appears to have significantly degraded the integrity of the fuel rods as evidenced by the results of the burst tests. Furthermore, no degradation of the cladding specifically caused by extended underwater storage was identified by any of the metallurgical examinations of the Shippingport fuel rods after nearly 21 yr of storage.

(a) Parker 1978; Hunt, Wood, and Bain 1979; Peehs et al. 1978; Huppert and Zimmerman 1977; Warner 1977; Flowers 1977; Johnson et al. 1980; Johnson 1977; Vesterlund and 01sson 1978; Mayman 1978; Huppert 1978. 
TABLE 11. Fuel Assembly Degradation Mechanisms and How They Were Addressed in the Current Fuel Examinations

Mechanism

Uniform Corrosion

Crud Effects $(a)$

Crevice Corrosion

(fuel bundle/assembly

components)

Stress Corrosion Cracking (SCC) on External Surfaces

Galvanic Corrosion

Galvanic Hydriding

Pitting

Corrosion at Cladding

Defects

Fission Product Attack

Internal Hydriding

External Hydriding

Effects at Welds
Shippingport Fuel Bundles 0551 and 0074 (Zircaloy-Clad Fuel Rods)

Visual inspection; metallography (ID and OD surface; oxide thickness)

Visual inspection; metallography

Visual inspection; metallography

Metal lography

Visual inspection and metallography of cable-fuel bundle contact area;

determination of cable composition

Metallography of cable-fuel bundle contact area; analysis of contact area for hydrogen by hot vacuum extraction

Visual inspection; metallography

Not applicable

Metallography (check for cracks in cladding inner surface)

Metallography; analysis for hydrogen

Metallography; analysis for hydrogen

Visual inspection; metallography

(a) For example, formation of differential aeration cells (Johnson 1977; Uhlig 1967) or concentration of aggressive species such as chlorides (Johnson 1977; Carlson 1963). 


\section{RELATION TO PREVIOUS EXAMINATIONS OF POOL-STORED SPENT FUELS}

The current trend in nuclear fuel management is to extend the burnup range for fuel in commercial power reactors to more fully utilize the nuclear fuel. Extended burnup programs presently underway in domestic commercial power plants involve the irradiation of fuel assemblies with Zircaloy-clad fuel rods up to expected assembly average burnups as high as $4752 \mathrm{GJ} / \mathrm{kgU}(55,000 \mathrm{MWd} / \mathrm{MTU})$ (Roberts et al. 1979). This trend to higher burnup fuel in conjunction with the current trend for extending pool storage times suggests a need to consider the effects of pool storage on fuels with extended burnups.

Unfortunately, most high-burnup fuels have resided in storage pools for relatively short periods; and past spent fuel examinations reflect this inverse relation between fuel burnup and pool storage time. This is illustrated in Figure 23 along with the relation between the present examinations and other spent fuel examinations.

The current examinations extend the data base to longer storage times and thereby provide an important contribution to defining the effects of extended water storage on fuel rod integrity. To date, none of the spent fuel examinations indicated any significant fuel rod degradation caused by underwater storage. There is now a broad concensus among spent fuel investigators that extended water storage of Zircaloy-clad fuel rods is a viable spent fuel management option. This concensus is based on spent fuel examinations specifically conducted in four countries (see Figure 23) to define the fuel cladding conditions after periods of water storage. 


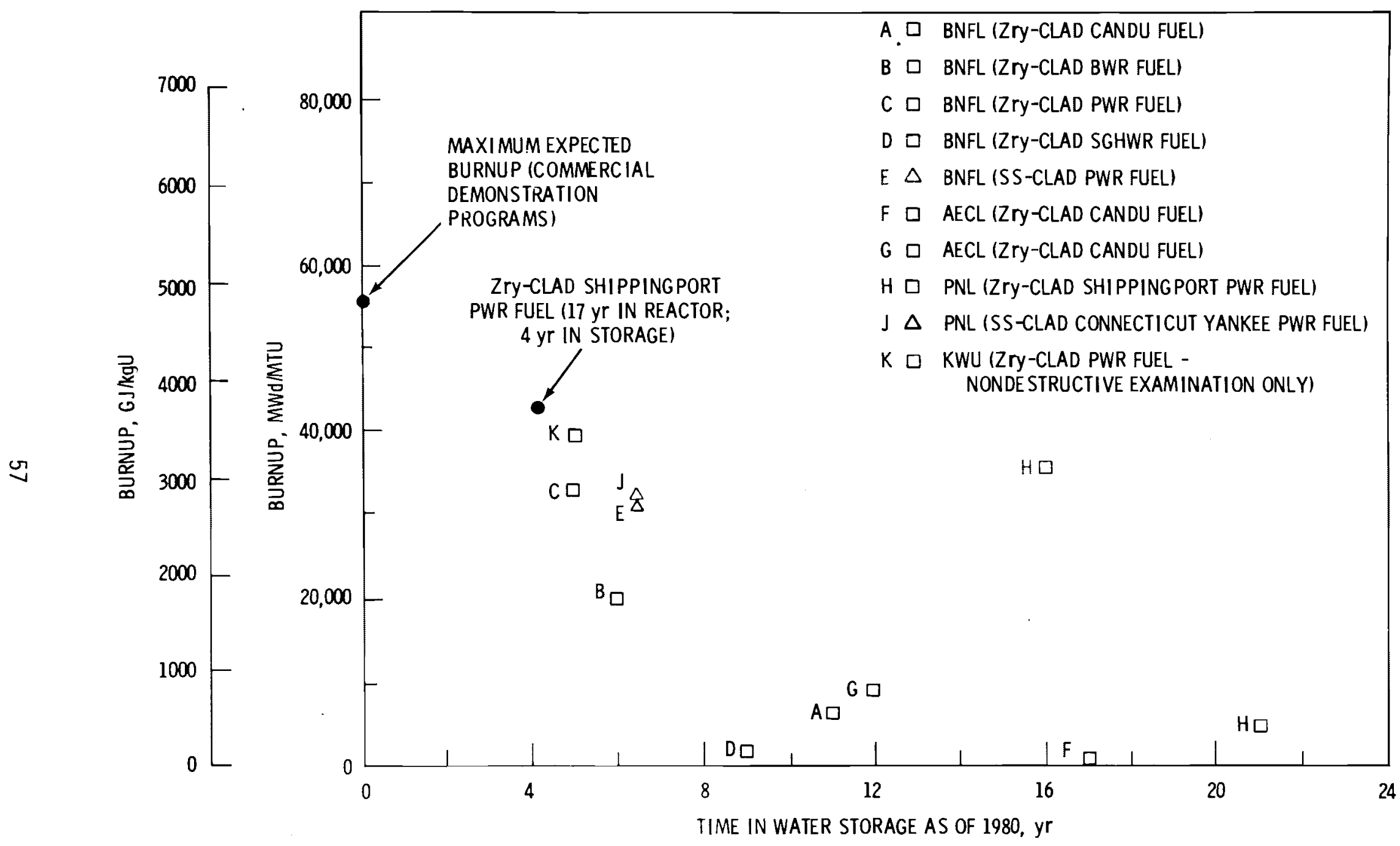

FIGURE 23. Summary of Spent Fuel Examinations to Define Effects of Water Storage 


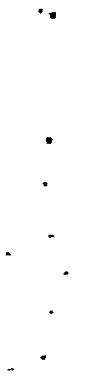




\section{FUTURE STORAGE}

The remaining fuel rods from bundles 0551 and 0074 will undergo further storage at the Receiving Basin for Offsite Fuels (RBOF), a deionized water pool at the Savannah River Plant, Aiken, South Carolina, that is used principally to store spent fuel from university research reactors. The rods will be available for periodic surveillance and examination as warranted. Details of these examinations have not yet been determined, but the extensive data base for these rods combined with their existing pool storage histories makes these fuel rods attractive candidates for future examinations to further define the effects of extended pool storage on fuel rod integrity. 



\section{REFERENCES}

Bailey, W. J., et al. 1981. Assessment of Current Onsite Inspection Techniques for Light-Water Reactor Fuel Systems-Discussion of Inspection Technique. NUREG/CR-1380, PNL-3325, Vo1. 2, Pacific Northwest Laboratory, Richland, Washington.

Carlson, A. B. March 1963. Contamination and Decontamination of Low Temperature, Water-Cooled Reactors, Part III Decontamination of Specimens of Reactor Piping. DP-793, Savannah River Laboratory, Aiken, South Carolina.

Dillon, R. L., and H. P. Maffei. October 1965. Metallurgy Research Chemical Metallurgy Studies in Support of Irradiation Processing Department on the Low-Temperature Zircaloy-2 Process Tube Hydriding Problem. BNWL-CC-329, Pacific Northwest Laboratory, Richland, Wash ington.

Flowers, R. H. October 1977. Results of an Examination of Irradiated 0xide Fuel Following Storage in Water. Testimony presented at Windscale Inquiry on Spent Fuel Reprocessing, Windscale, United Kingdom.

Glatter, J., et al. 1958. The Manufacture of PWR Blanket Fuel Elements Containing High Density 102 . Proceedings of the Second United Nations International Conference on the Peaceful Uses of Atomic Energy, Vol.6, p. 2830, pp. 630-644.

Henke, R. L., ed. March 1966. Summary Design Report for Melba Test in PWR Core 2 Blanket. WAPD-TM-483, Bettis Atomic Power Laboratory, Pittsburgh, Pennsylvania.

Hillner, E. 1974. "Corrosion and Hydriding Performance of Zircaloy Tubing After Extended Exposure in the Shippingport Pressurized Water Reactor." Zirconium in Nuclear Applications, ASTM STP 551, American Society for Testing and Materials, pp. 449-462.

Hillner, E. January 1980. Corrosion and Hydriding Performance Evaluation of Three Zircaloy-2 Clad Fuel Assemblies After Continuous Exposure in PWR Cores 1 and 2 at Shippingport, Pennsylvania. WAPD-TM-1412, Bett is Atomic Power Laboratory, West Mifflín, Pennsylvania.

Hunt, C.E.L., J. C. Wood, and A. S. Bain. 1979. Long-Term Storage of Fuel in Water. AECL-6577, Chalk River Nuclear Laboratories, Ontario, Canada.

Huppert, K. L. 1978. "Spent Fuel Storage - Philosophies and Experience." In Proceedings of NEA Seminar on Storage of Spent Fuel Elements, June 20-23, 1978, Madrid, Spain.

Huppert, K. L., and G. Zimmerman. 1977. "Experience with Regard to Long-Term Storage of LWR Fuel Elements." Reactor Congress, March 29-April 1, 1977, Mannheim, AED-CONF-77-013-112, pp. 447-450 (in German). 
Johnson, A. B., Jr. 1977 Behavior of Spent Nuclear Fuel in Water Pool Storage. BNWL-2256, Pacific Northwest Laboratory, Richland, Washington.

Johnson, A. B., Jr. 1978. "Impacts of Reactor-Induced Defects on Spent Fuel Storage." In Proceedings of NEA Seminar on Storage of Spent Fuel Elements, June 20-23, 1978, Madrid, Spain.

Johnson, A. B., Jr. 1979. "Spent Fuel Storage Experience." Nuclear Tech. $43: 165-173$.

Johnson, A. B., Jr., et al. May 1980. Annual Report-FY-1979, Spent Fuel and Fuel Pool Component Integrity. PNL-3171, Pacific Northwest Laboratory, Richtand, washington.

Knorr, D. B., and R. M. Pelloux. May 1981. Research on Mechan isms of Stress Corrosion Cracking in Zircaloy. PNL-3860, D0E/ET/34215-24, prepared for Pacific Northwest Laboratory by Massachusetts Institute Technology, Cambridge, Massachusetts.

Larson, L. D. December 1960. Dimensional Inspection of Irradiated PWR Core 1 Blanket Fuel. WAPD-TM-262, Bettis Atomic Power Laboratory, Pittsburgh, Pennsytvania.

Lynam, L. R. December 1961. Metallurgical Examination of Fuel Rod from PWR-1 Blanket at End of Second Seed Life. WAPD-TM-308, Bettis Atomic Power Laboratory, Pittsburgh, Pennsylvanía.

Lynam, L. R., et a1. September 1962. Fabrication Defects Observed in PWR Core 1 Blanket Fuel Rods. WAPD-TM-321, Bettis Atomic Power Laboratory, Pittsburgh, Pennsylvania.

Lynam, L. R. April 1963. Examination of PWR Core 1 Blanket Fuel Rod for Microstructural Changes, Hydrogen Pickup, Burst Strength and Fission Gas Release at the End of the Second Seed Life. WAPD-TM-326, Bett is Atomic Power Laboratory, Pittsburgh, Pennsylvania.

Lynam, L. R. August 1964. Metallurgical Examination of PWR Core 1 Blanket Fuel Rods at the End of the Third Seed Life. WAPD-TM-433, Bettis Atomic Power Laboratory, Pittsburgh, Pennsylvania.

Mayman, S. A. 1978. "Canadian Experience with Wet and Dry Storage Concepts." Presented at the Executive Conference on Spent Fuel Policy and Its Implications, April 2-5, 1978, Buford, Georgia.

Parker, J. 1978. The Windscale Inquiry. Vol. 1, p. 6, Report and Annexes 3-5, Her Majesty's Stationary Office, London, January 26, 1978.

Peehs, M., et a1. 1978. "Behavior of Spent LWR Fuel Assemblies." In Proceedings of NEA Seminar on Storage of Spent Fuel Elements, June 20-23, 1978, Madrid, Spain. 
Roberts, J.T.A., et al. 1977. "On the Pellet-Cladding Interaction Phenomenon." Nuclear Tech. 35:131.

Roberts, J.T.A., et al. 1979. LWR Fuel Performance Program: Progress in 1978. EPRI NP-1024-SR, Electric Power Research Institute, Palo Alto, California.

Rosenbaum, H. S. September 1980. Demonstration of Fuel Resistant to PelletCladding Interaction Phase-2 Third Semiannual Report January-June 1980. Prepared by General Electric for Commonwealth Research Corporation.

Rubin, B. February 1961a. Examination of PWR Core 1 Blanket Fuel Rods for Microstructure, Hydrogen Pickup and Burst Strength. WAPD-TM-264, Bettis Atomic Power Laboratory, Pittsburgh, Pennsylvania.

Rubin, B. February 1961b. Fission Gas Release in PWR Core 1 Blanket Fuel Rods Upon Conclusion of Seed 1 Life. WAPD-TM-263, Bettis Atomic Power Laboratory, Pittsburgh, Pennsylvania.

Rub in, B., and L. R. Lynam. 1966. "Examination of Fuel and Cladding in PWR-1 Blanket Rods." Nuclear Applications 2:499-504.

Skaritka, J., and J. A. Iorii. April 1980. Operational Experience with Westinghouse Cores (up to December 31, 1979). WCAP-8183, Rev. 9, Bettis Atomic Power Laboratory, Pittsburgh, Pennsytvania.

Sphar, C. D. February 1962. Evaluation of Isotopic Content of Irradiated Natural Uranium Dioxide Rods from PWR Core 1. WAPD-TM-265, Bett is Atomic Power Laboratory, Pittsburgh, Pennsylvania.

Uhlig, H. H. 1967. Corrosion and Corrosion Control. John Wiley and Sons, New York, p. 11.

Vesterlund, G., and T. 0lsson. May 1978. Degraderingsmeckanismer Vid Bassanglagering och hantering av Utbrant kraftreaktorbransTe. RB 78-29, ASEA-ATOM, Vasteras, Sweden: English transTation, BNWL-TR-320, Pacific Northwest Laboratory, Richland, Washington.

Warner, B. F. September 1977. The Storage in Water of Irradiated Oxide Fuel Elements. Testimony presented at Windscale Inquiry on Spent Fuel Reprocessing, Windscale, United Kingdom.

Wood, J. C. 1973. "Factors Affecting Stress Corrosion Cracking of Zircaloy in Iodine Vapour." J. of NuCl. Mat1. 45:105-122. 

APPENDIX A

EXPERIMENTAL PROCEDURES AND IDENTIFICATIONS 
APPENDIX A

\section{EXPER IMENTAL PROCEDURES AND IDENTIFICATIONS}

The hot cell examinations of the Shippingport fuel rods consisted of a series of nondestructive and destructive tests. Shippingport fuel configurations are not typical of standard fuel rods; $(a)$ and modifications in the standard procedures for fuel rod removal, fission gas collection, and burst testing were required. The operating procedures that required modification and the differences in the sample identification used during the examinations and in this report are presented in this appendix. The differences in sample identification are important for future reference in the event that fuel rods are examined after additional water storage.

\section{FUEL ROD IDENTIFICATION}

Identification numbers for individual Shippingport fuel rods were not available; the numbering system reported previously (Rubin 1961b) was used to indicate the relative positions of the fuel rods in the bundle. This numbering system is shown in Figure A.1 and was used exclusively for bundle 0074 .

Upon arrival at the Battelle-Columbus Laboratories (BCL) hot cells, the relative position of the seven- and eight-rod clusters in bundle 0551 was not known. Consequently, a reference rod was arbitrarily selected as rod 1 for each cluster and the remaining rods were numbered consecutively (i.e., 1 through 8 for the eight-rod cluster and 1 through 7 for the seven-rod cluster. These rod designations were used by BCL throughout the examinations.

From detailed examinations of the fuel rod clusters and previously reported destructive examinations of fuel rods from bundle 0551, it was determined that the eight-rod array came from rod positions 1 through 8 , and the seven-rod array came from rod positions 13 through 19. Table A.1 shows the

(a) One difference is the active full length: in the former fuel it is $0.231 \mathrm{~m}$ and in the latter fuel it is $3.66 \mathrm{~m}$. 


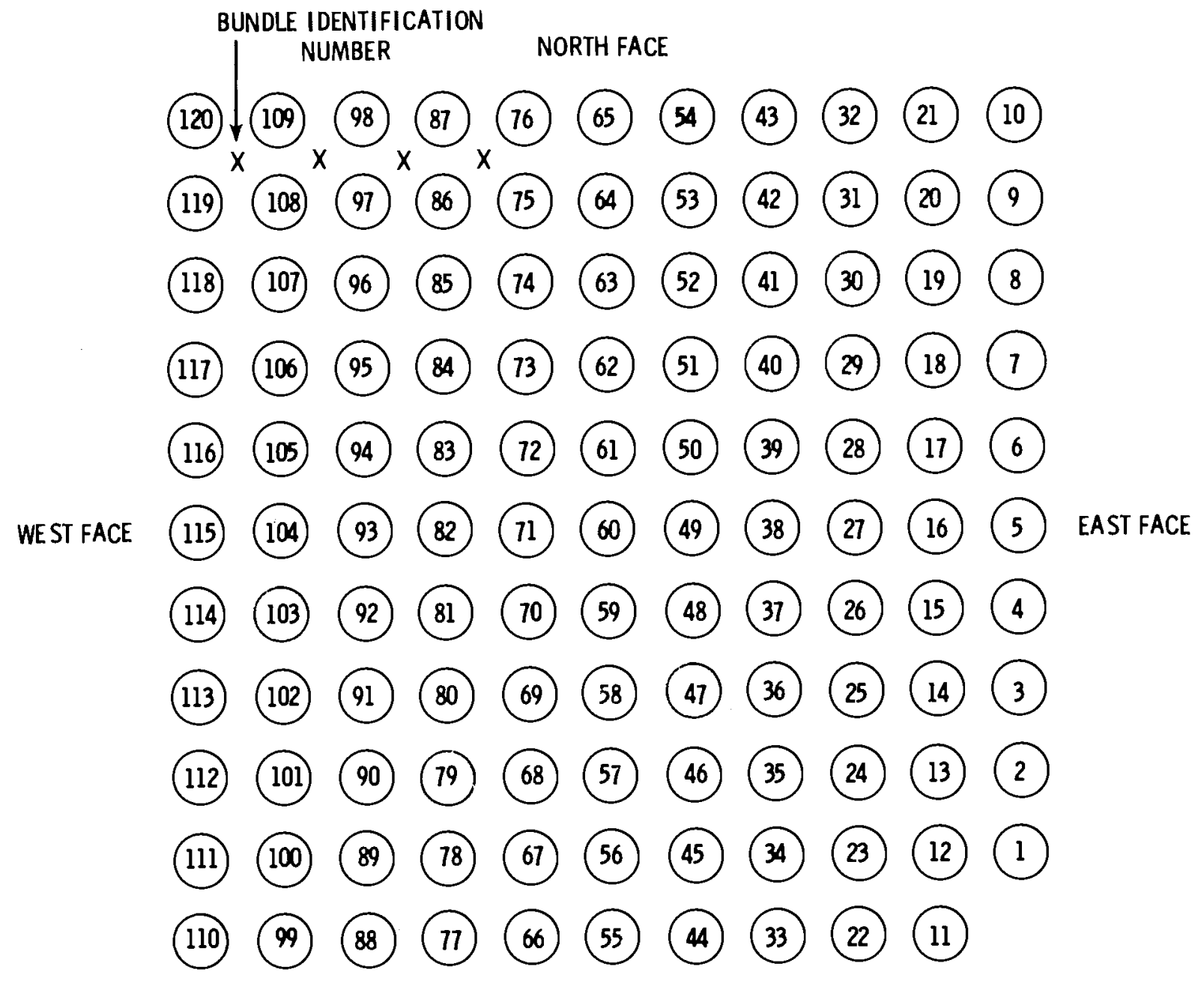

SOUTH FACE

TOP VIEW

FIGURE A.1. Plan View of PWR Core 1 Blanket Fuel Bundle 0074 with Rod Numbering Scheme

correspondence between the $B C L$ rod identifications and the relative fuel rod positions in the bundle. The fuel rod numbers used in this report correspond to the relative rod positions within the bundle and not to $B C L$ 's rod designations. 
TABLE A.1. Correspondence Between BCL Rod Identification Number and Rod Position Within Bundle 0551

\begin{tabular}{|c|c|c|c|}
\hline \multicolumn{2}{|c|}{ Seven-Rod Array } & \multicolumn{2}{|c|}{ Eight-Rod Array } \\
\hline $\begin{array}{l}\text { BCL Rod } \\
\text { Number }\end{array}$ & $\begin{array}{c}\text { Position Within } \\
\text { Bundle 0551 } \\
\end{array}$ & $\begin{array}{l}\text { BCL Rod } \\
\text { Number } \\
\end{array}$ & $\begin{array}{l}\text { Position Within } \\
\text { Bundle 0551 } \\
\end{array}$ \\
\hline 1 & 13 & 1 & 8 \\
\hline 2 & 14 & 2 & 7 \\
\hline 3 & 15 & 3 & 6 \\
\hline 4 & 16 & 4 & 5 \\
\hline 5 & 17 & 5 & 4 \\
\hline 6 & 18 & 6 & 3 \\
\hline 7 & 19 & 7 & 2 \\
\hline & & 8 & 1 \\
\hline
\end{tabular}

\section{ROD REMOVAL AND MACHINING}

After visual examination of the as-received fuel bundle and two linear arrays, individual fuel rods $(4,5,13$, and 19 from bundle 0551 and 110,111 , 119, and 120 from bundle 0074) were removed using an in-cell milling machine equipped with a $0.6-\mathrm{mm}(0.025-\mathrm{in}$.) thick circular metal blade. The saw blade and end plate were cooled with water during the cutting operation. Single rods were marked with paint dots for orientation and identification. The remaining arrays from bundle 0551 (one five-rod array and two three-rod arrays) were marked with saw cuts to preserve orientation and identification of these arrays.

Figure A.2 shows the saw cut markings used to identify the three remaining arrays. The five-rod array was from the original 7-rod cluster and contains rods 14 thrugh 18. The saw mark was at the top end of rod 14 (BCL rod 2) and extended into the cladding area. However, visual examination indicated that the cladding was not breached.

Two three-rod arrays were left from the original eight-rod cluster after rods 4 and 5 had been removed. The three-rod array containing rods 1 through 3 was marked with two saw cuts at the upper end of rod 3 ( $B C L$ rod 6 ) while the other three rod clusters containing rods 6 through 8 were marked with a single saw cut at the top of rod 8 ( $B C L \operatorname{rod} 1)$. 


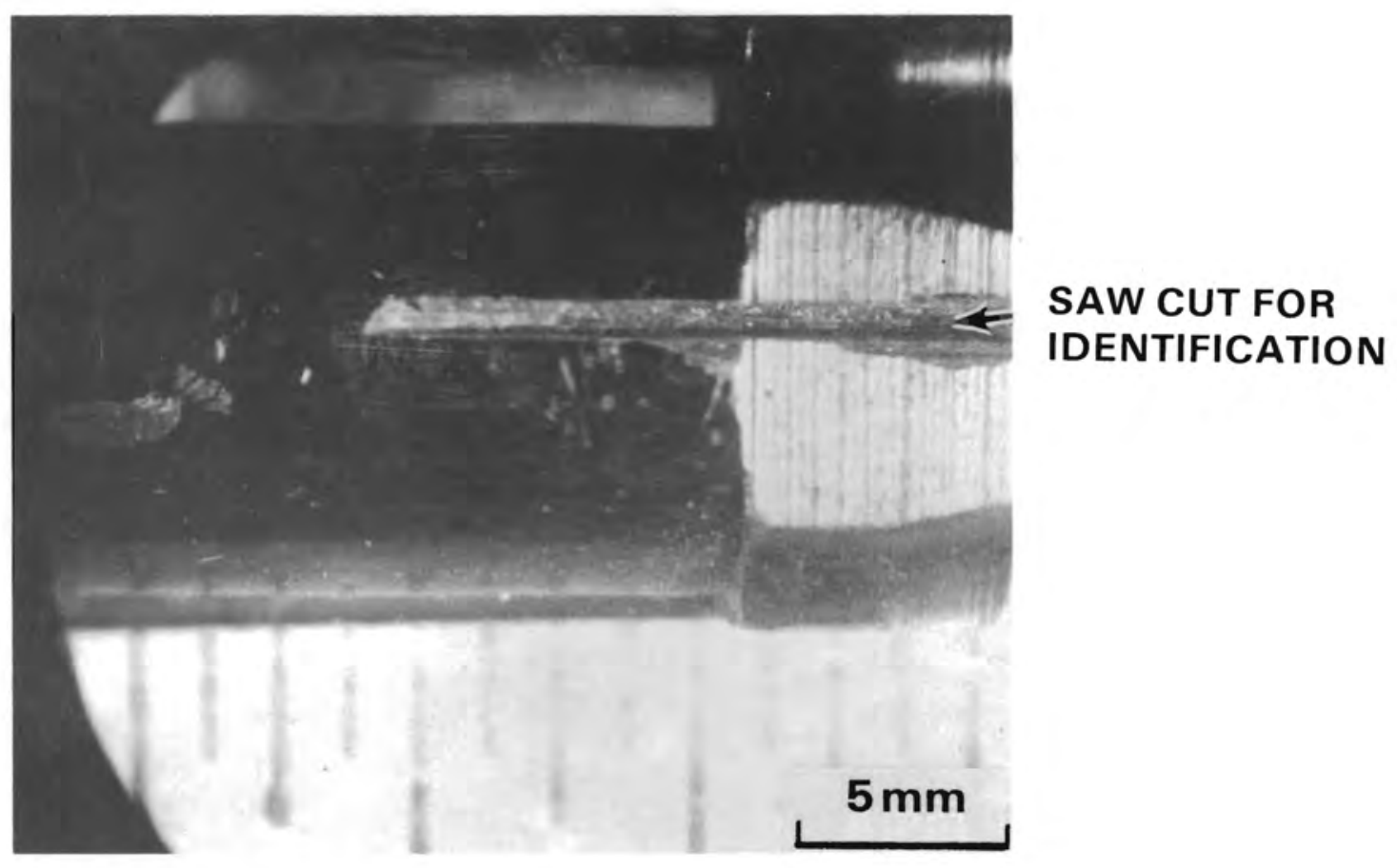

Neg. C8326

Rod 14 - Bundle 0551

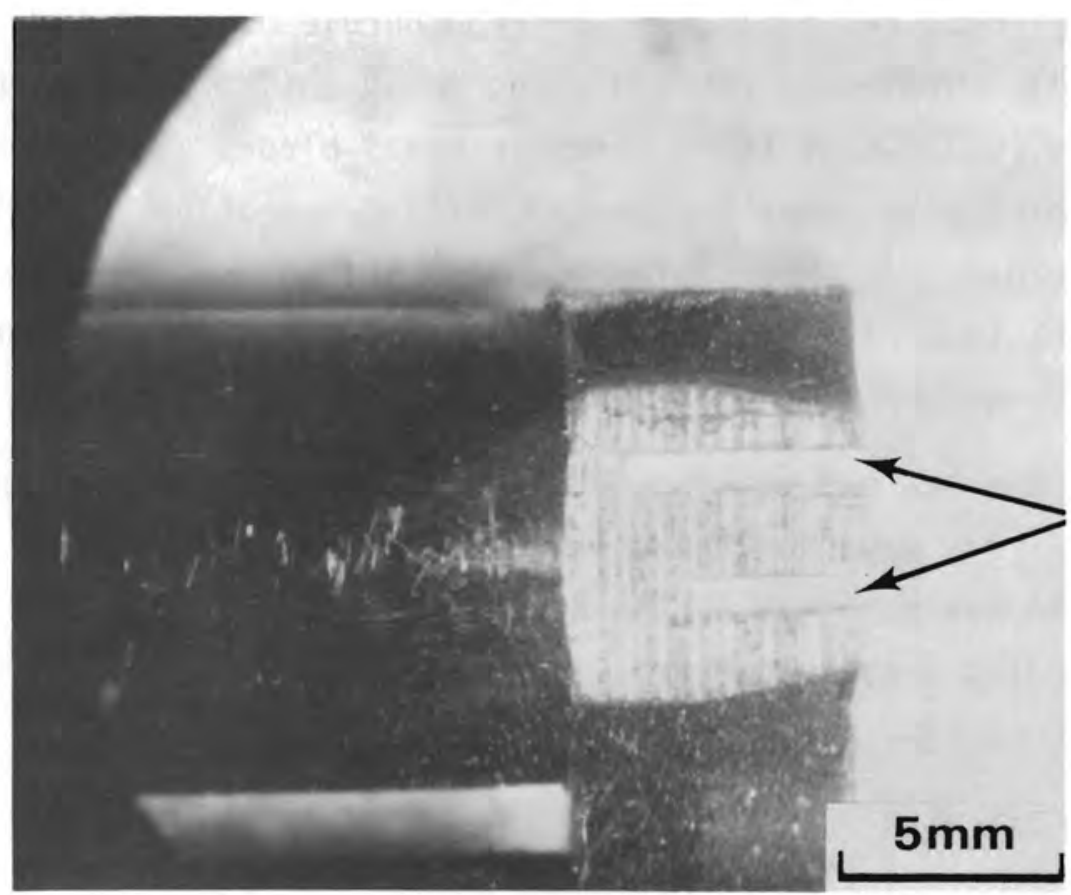

SAW CUTS FOR IDENTIFICATION

Neg. $C 8324$

$$
\text { Rod } 3 \text { - Bundle } 0551
$$

FIGURE A.2. Identification Marks for the Remaining Fuel Rod Clusters from Bundle 0551 


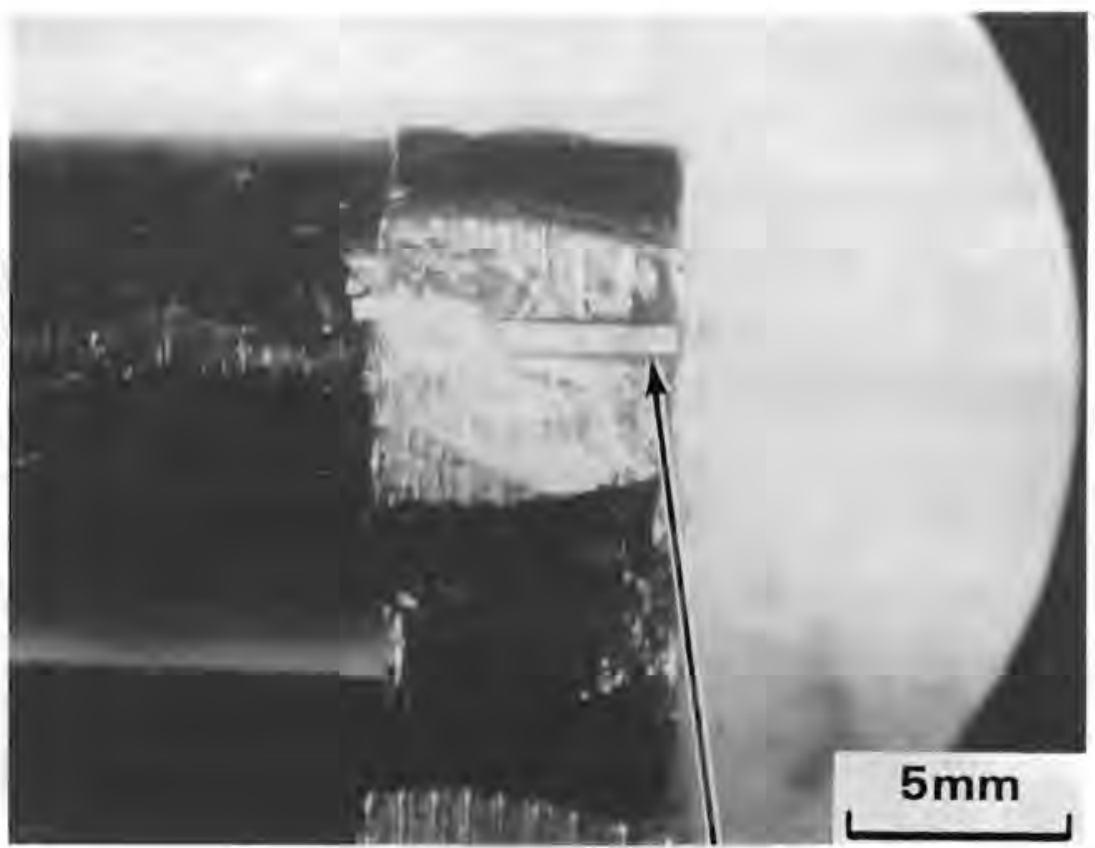

SAW CUT FOR IDENTIFICATION

Neg. $C 8325$

Rod 8 - Bundle 0551

FIGURE A.2. (contd)

During sectioning of bundle 0074, the corroded and frayed steel lifting cable was removed and replaced with a 1/8-in. stainless steel cable. The new cable was looped through the holes in the top and bottom tube sheets between fuel rods $9,10,20$, and 21 and between fuel rods $89,90,100$, and 101 (see Figure A.1). The cable clamp was positioned at the top end of the bundle.

For profilometry, eddy current scans, and gamma scans, the "squared" ends of each fuel rod had to be machined to a right circular cylindrical shape using an in-cell lathe. Each rod was machined to a diameter of approximately $10.4 \mathrm{~mm}$ ( 0.411 in.). To reduce the distance required for drilling during puncturing and fission gas collection, each rod was end-drilled using a 3/16-in. drill to a depth of about $8.9 \mathrm{~mm}(0.35 \mathrm{in.})$, which left about $3.8 \mathrm{~mm}(0.15 \mathrm{in}$.$) to be$ drilled to penetrate the $12.7-\mathrm{mm}(0.5-\mathrm{in}$.$) end cap during puncturing. Rods 4$ and 19 of bundle 0551 and rods 111 and 119 of bundle 0074 were subsequently drilled using a 19/64-in. drill to a depth of about $8.9 \mathrm{~mm}(0.35 \mathrm{in.})$ and finally reamed using a 5/16-in. reamer in preparation for burst testing. 
Following visual inspection, rods 4 and 13 of bundle 0551 and rods 110 and 120 of bundle 0074 were sectioned to obtain samples for hydrogen analysis, burnup analysis, and metallography. The location of the individual samples was shown in Figure 12 of the body of this report.

A water-cooled abrasive cut-off wheel was used to section the fuel rods. The cut sections were numbered consecutively starting at the bottom end, and a white orientation mark was placed at the top of each section. Sample identification was based on the rod number, section number, and the axial location of the sample relative to the bottom end of the fuel rod.

As discussed previously, the BCL rod numbers for bundle 0551 were not used in this report. Therefore, the correspondence between the BCL sample identification and that used in this report is given in Table A.2 for future reference.

\section{FISSION GAS COLLECTION}

The internal fuel rod gas content was determined by drilling a small hole through one end cap and measuring the pressure increase in an evacuated system of known volume. The end caps had been predrilled to a depth of about $8.9 \mathrm{~mm}$ to minimize drilling time for final puncture. The fixture used to puncture the fuel rods is shown schematically in Figure A.3. The predrilled fuel rod is inserted into the fixture, and a vacuum seal enables the drill to move axially and puncture the fuel rod through the end cap.

Prior to rod puncture, the prepunch system volume was calibrated by pressurizing the punch chamber with helium and expanding it into a known volume. This volume is added to the calibrated volume of the McCleod gage to obtain the total volume of the prepunch system. The entire gas collection system was then evacuated to less than $5 \mu \mathrm{m}$, and the leak rates from the in-cell portion of the system were measured. As expected, the maximum leak rates in the in-cell portion of the system occurred with the drill motor running; the leak rates ranged from 3 to $15 \mu \mathrm{m} / \mathrm{min}$. With the motor off, the leak rates were generally less than $3 \mu \mathrm{m} / \mathrm{min}$. 
TABLE A.2. Correspondence Between BCL Sample Identification Number and the Sample Number Used in this Report (Figure 12)

\begin{tabular}{|c|c|c|c|}
\hline $\begin{array}{l}\text { Bundle } \\
\text { Number } \\
\end{array}$ & $\begin{array}{l}\text { Rod } \\
\text { Number }\end{array}$ & $\begin{array}{l}\text { PNL } \\
\text { Sample Number } \\
\end{array}$ & $\begin{array}{c}\text { BCL Sample } \\
\text { Identification Number }\end{array}$ \\
\hline \multirow[t]{4}{*}{0551} & 5 & $M-1$ & $4-1$ \\
\hline & & $M-2$ & $4-43 / 4$ in. (a) \\
\hline & & $\mathrm{H}-1$ & $4-2$ \\
\hline & & $\mathrm{H}-2$ & $4-5$ \\
\hline \multirow[t]{5}{*}{0551} & 13 & $M-1$ & $1-53 / 16$ in. \\
\hline & & $M-2$ & $1-71 / 2$ in. \\
\hline & & $\mathrm{H}-1$ & $1-2$ \\
\hline & & $\mathrm{H}-2$ & $1-6$ \\
\hline & & BU-1 & $1-4 A$ \\
\hline \multirow[t]{9}{*}{0074} & 110 & $M-1$ & $110-31 / 2$ in. \\
\hline & & $M-2$ & $110-71 / 2$ in. \\
\hline & & $M-3$ & $100-00$ \\
\hline & & $\mathrm{H}-1$ & $110-3$ \\
\hline & & $\mathrm{H}-2$ & $110-6$ \\
\hline & & $\mathrm{H}-3$ & $110-0 A$ \\
\hline & & $\mathrm{H}-4$ & $110-0 B$ \\
\hline & & $\mathrm{H}-5$ & $110-0 C$ \\
\hline & & $\mathrm{Bu}-1$ & $110-3 A$ \\
\hline \multirow[t]{4}{*}{0074} & 120 & $M-1$ & $120-1$ \\
\hline & & $M-2$ & $120-5$ \\
\hline & & $\mathrm{H}-1$ & $120-2$ \\
\hline & & $\mathrm{H}-2$ & $120-5$ \\
\hline
\end{tabular}

(a) Distance designations are given in inches from the bottom end of the fuel rods. 


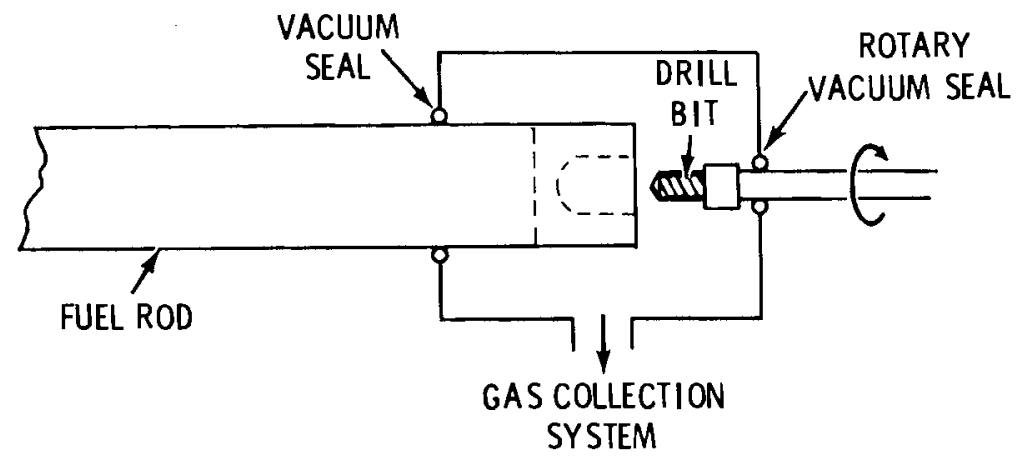

FIGURE A.3. Schematic of Fixture Used to Puncture the Shippingport Fuel Rods

Upon rod puncture, the system pressure was measured using the McCleod gage at 2-min intervals until the system equilibrated. The rod gas was then expanded into a calibrated volume and a second pressure was recorded. The gas content of the fuel rods was calculated from these data and the internal fuel rod free volume, which was estimated from the preirradiated fuel and fuel rod dimensions. The small internal volumes of the Shippngport fuel rods, $\sim 0.5 \mathrm{ml}$, precluded experimental measurement of the fuel rod internal volumes.

The released gases were collected in small $-30-m i$ vials via a diffusion pump-Toepler pump combination, and the gas compositions were determined by mass spectroscopy.

\section{BURST TESTING}

To compare the present results to those reported previously, the burst tests were conducted using essentially the same procedures reported by Rubin (1961a). This involved slowly pressurizing the fuel rods with water through the small hole drilled in one end cap during gas collection. The end cap had been drilled and reamed to accommodate an 0-ring sealed nozzle though which the pressurized water was pumped into the fuel rod.

The fixture used to support the rods during burst testing is shown in Figure A.4. Six supports were used to hold the fuel rod horizontal and to prevent buckling during testing. An adjustable stop provided end restraint to hold the fuel rod on the pressurizing nozzle; the cover minimized the spread of irradiated particles upon bursting. 


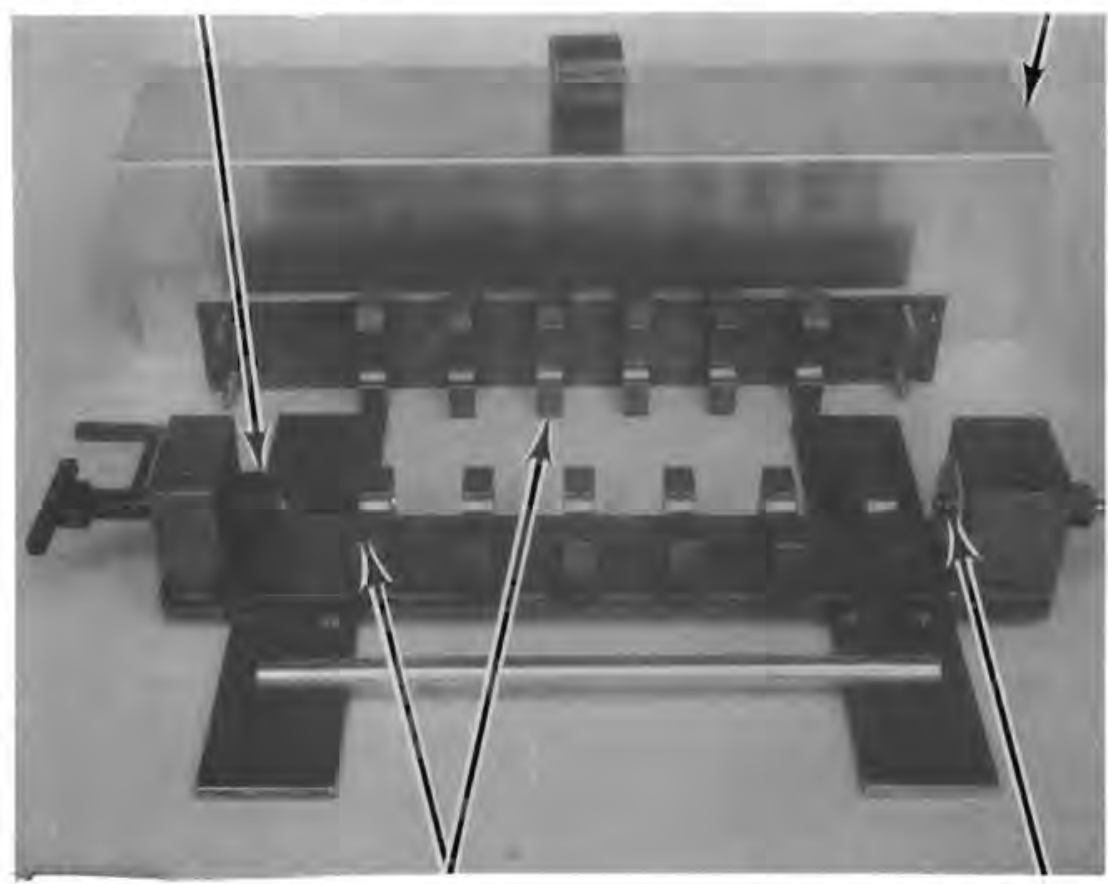

FUEL ROD SUPPORTS

WATER INLET

Neg. $C 8550$

FIGURE A.4. Burst Test Fixture for the Shippingport Fuel Rods

Burst tests at BCL normally use silicone $0 i 1$ as the pressurizing medium, and a reservoir that contained an oil-water interface was introduced into the high-pressure line for burst testing the Shippingport fuel rods. No other modifications to the system were necessary.

The fuel rods were pressurized in 13.6-MPa (2000-psi) increments up to $68 \mathrm{MPa}(10,000 \mathrm{psi})$ and continuous $1 \mathrm{y}$ thereafter. The pressurization rate was about $0.11 \mathrm{MPa} / \mathrm{s}$ (1000 psi/min) with 1-min hold periods at each of the pressure increments. The purpose of the incremental hold periods was to assure pressure equalization along the fuel rod and to check for defective cladding (a pressure drop would be expected during the hold period if a leak existed). The pressurization rates were not reported by Rubin (1961a) or Lynam (1963); and, therefore, exact duplication of the test was not possible. However, the fuel rods were slowly pressurized in all of the tests and significant differences in the results are not expected. 
Pressure-volume curves were used to determine the internal pressure at the $0.2 \%$ yield strength while the maximum pressure was used for the burst pressure. Yield and fracture stresses were calculated using the relation:

$$
\sigma=\frac{P d}{2 t}
$$

where $\sigma=$ circumferential stress

$P=$ internal pressure at yielding or burst

$d=$ internal diameter $(9.2 \mathrm{~mm})$

$\mathrm{t}=$ wall thickness $(0.635 \mathrm{~mm})$.

The internal diameters and wall thicknesses used in the calculatioris correspond to the values used by Rubin (1961a). Failure strains were determined by measuring the fuel rod circumference at the region of the initial failure and using the relation:

$$
\varepsilon=\frac{C_{f}-C_{i}}{C_{i}}(100)
$$

$$
\text { where } \begin{aligned}
\varepsilon & =\text { failure strain } \\
C_{f} & =\text { rod circumference after burst test } \\
C_{j} & =\text { initial rod circumference }(32.8 \mathrm{~mm}) .
\end{aligned}
$$




\section{DISTRIBUTION}

No. of

Copies

OFFSITE

A. A. Churm

DOE Patent Division

9800 South Cass Avenue

Argonne, IL 60439

DOE Office of Nuclear Waste

Management

ATTN: 0. P. Gormley, Chief

Fuel Storage Branch

Division of Spent Fuel Storage and Transfer

Headquarters

Washington, DC 20545

DOE Office of Nuclear Waste Management

ATTN: M. J. Lawrence, Director

Division of Spent Fuel Storage and Transfer

Headquarters

Washington, DC 20545

DOE Office of Safeguards and Security

ATTN: Dr. Samuel C. T. McDowell Assistant Director for Research and Development

MS A2 1016

Washington, DC 20545

DOE Division of Waste Management

ATTN: Director

Washington, DC 20545

DOE Albuquerque Operations

Office

ATTN: Manager

P.0. Box 5400

Albuquerque, NM 87115
No. of

Copies

DOE Chicago Operations Office

ATTN: Manager

9800 South Cass Avenue

Argonne, IL 60439

DOE Columbus Program Office

Richland Operations office

ATTN: J. L. Neff, Program Manager

$505 \mathrm{King}$ Avenue

Columbus, $\mathrm{OH} 45201$

DOE Idaho Operations Office

ATTN: J. P. Hamric, Director

Nuclear Fuel Cycle Division

550 2nd Street

Idaho Falls, ID 83401

DOE Nevada Operations Office

ATTN: Manager

P.0. Box 14100

Las Vegas, NV 89114

DOE Oak Ridge Operations Office

ATTN: D. E. Large, Manager

Radioactive Waste Management Program

P.0. Box E

Oak Ridge, TN 37830

DOE Rocky Flats Area Office

ATTN: Area Manager

P.0. Box 298

Golden, C0 80401

DOE San Francisco Operations office

ATTN: Director Nuclear Energy Division

1333 Broadway

Oakland, CA 94612 
DOE Savannah River Operations Office

ATTN: Manager

P.0. Box A

Aiken, SC 29801

DOE Savannah River Operations Office

ATTN: Director Spent Fuel Project office

P.0. Box A

Aiken, SC 29801

DOE Savannah River Operations Office

ATTN: M. C. Kirkland

P.0. Box A

Aiken, SC 29801

27 DOE Technical Information Center

Allied-General Nuclear Services ATTN: P. F. Highberger

P.0. Box 847

Barnwe11, SC 29812

Argonne National Laboratory

ATTN: C. J. Roberts

9700 S. Cass Ave.

Argonne, IL 60439

Atomic Industrial Forum

ATTN: E. Gordon

7101 Wiscons in Ave., 12th Floor

Washington, DC 20014

Babcock \& Wilcox Co.

Lynchburg Research Center

ATTN: M. N. Baldwin

P.0. Box 12600

Lynchburg, VA 24505

Battelle-Columbus Laboratories

ATTN: Dr. J. Beavers

505 King Avenue

Columbus, $\mathrm{OH} 43201$
Battelle-Columbus Laboratories

ATTN: Dr. R. W. Klingensmith

505 King Avenue

Columbus, $\mathrm{OH} 43201$

Battelle-Columbus Laboratories

ATTN: L. M. Lowry

505 King Avenue

Columbus, $\mathrm{OH} 43201$

Battelle Project Management

Division

ATTN: Manager, ONWI

505 King Avenue

Columbus, $\mathrm{OH} 43229$

Boeing Engineering and Construction Company

ATTN: Dr. K. Bjornerud

P.0. Box 3707

Seattle, WA 98124

Brookhaven National Laboratory

ATTN: Chairman

Department of Nuclear Energy

Upton, NY 11973

Brookhaven National Laboratories

ATTN: Dr. J. R. Weeks

Corrosion Science

Building 130

Upton, NY 11973

Commonwealth Edison

Station Nuclear Engineering Dept.

ATTN: George P. Wagner

P.0. Box 767

Chicago, IL 60690

EG\&G Idaho, Inc.

ATTN: Dr. D. D. Keiser, Manager

Fuels and Materials Division

P.0. Box 1625

Idaho Falls, ID 83401 
Edison Electric Institute

ATTN: Steven Kraft

1111 19th Street, N.W.

Washington, DC 20036

Electric Power Research Institute

ATTN: H. Ocken

3412 Hillview Avenue

P.0. Box 10412

Palo Alto, CA 94304

Electric Power Research Institute

ATTN: P. F. Williams

Technical Library

3412 Hillview Avenue

P.0. Box 10412

Palo Alto, CA 94304

Exxon Nuclear Corporation

Process Development a Support Section

Idaho Chemical Programs

550 Second Street

Idaho Falls, ID 83401

General Atomic Company

ATTN: J. Shefcik

P.0. Box 81608

San Diego, CA 92138

General Electric Company

Morr is Operation

ATTN: E. E. Voiland

Morris, IL 60450

General Electric Uranium Management Corp.

ATTN: B. F. Judson, Vice President and Manager

GEUMCO-Engineering

175 Curtner Avenue (Mail Code 858)

San Jose, CA 95125

Kaman Sciences Corporation

ATTN: N. J. Becar

$\mathrm{Sr}$. Research Scientist

P.0. Box 7463

Colorado Springs, C0 80933
Lawrence Livermore Laboratory

ATTN: F. R. Wondolowsk i

P.0. Box 808

Livermore, CA 94550

Los Alamos Scientific Laboratory

ATTN: D. D. Cobb

P.0. Box 1663

Los Alamos, NM 87544

Management Analys is Company

ATTN: R. C. Traylor

11100 Roselle Street

San Diego, CA 92121

NL Industries, Inc.

ATTN: George L. Stukenbroeker 1130 Central Avenue

Albany, NY 12205

Nuclear Assurance Corporation

ATTN: J. Viebrock

24 Executive Park West

Atlanta, GA 30329

Nuclear Energy Service, Inc. ATTN: William J. Marrion

NES Division

Shelter Rock Road

Danbury, CT 06810

Nuclear Fuel Services, Inc.

ATTN: J. P. Duckworth, Plant Manager

P.0. Box 124

West Valley, NY 14171

Nuclear Services Corporation

ATTN: Dr. M. Reier

1700 Dell Avenue

Campbell, CA 95008

Oak Ridge National Laboratory

ATTN: W. G. Stockdale

Union Carbide Corporation

P.0. Box X

Oak Ridge, TN 37830 
Resource Planning Associates, Inc. ATTN: Alva Collins 1901 L. Street, N.W. Washington, DC 20036

Ridihalgh, Eggers, and Associates ATTN: P. E. Eggers

2112 Iuka Avenue

Columbus, $\mathrm{OH} 43201$

Rockwell International

ATTN: L. L. Richey, Program Manager Waste Conversion and Fixation

P.0. Box 464

Golden, C0 80401

Sandia Laboratories

ATTN: R. M. Jefferson, Manager

Nuclear Materials Transportation Technology

Department 4550

Albuquerque, NM 87185

E. I. du Pont de Nemours and Co. Savannah River Laboratory

Technical Info. Svc. 773A

Aiken, SC 29801

E. I. du Pont de Nemours and Co. Atomic Energy Division

ATTN: W. H. Baker

Building 777M

Savannah River Plant

Aiken, SC 29801

E. I. du Pont de Nemours and Co.

Atomic Energy Division

ATTN: F. D. King

Building 777M

Savannah River Plant

Aiken, SC 29801

Science Applications, Inc.

ATTN: Dr. E. A. Straker

1200 Prospect Street

La Jolla, CA 92038
College of Engineering

ATTN: A. Hill

University of South Carolina

Columbia, SC 29208

S. M. Stoller Corporation

ATTN: W. A. Franks

1250 Broadway

New York, NY 10001

Tennessee Valley Authority

ATTN: Robert Davidson

403 Power Bldg.

6 th and Market Street

Chattanooga, TN 37402

Union Carbide Corporation

Nuclear Division

ORGDP Records Department

P.0. Box P

Oak Ridge, TN 37830

U.S. Nuclear Regulatory Commission

ATTN: Director

Division of Inspection and

Enforcement

101 Marietta Street

Suite 3100

Atlanta, GA 30303

U.S. Nuclear Regulatory Commission

ATTN: Group Leader for Spent

Fuel Storage Installation

Division of Fuel Cycle and Material Safety

Washington, DC 20545

Westinghouse Electric Corporation Bett is Atomic Power Laboratory

ATTN: R. Atherton

P.0. Box 79

West Mifflin, PA 15122

Westinghouse Electric Corporation

Bettis Atomic Power Laboratory

ATTN: W. M. Cella

P.0. Box 79

West Mifflin, PA 15122 
No. of

Copies

E. C. Dayis

Westinghouse Electric Corporation

Bett is Atomic Power Laboratory

P.0. Box 79

West Mifflin, PA 15122

R. A. Fredrickson

Westinghouse Electric Corporation Bettis Atomic Power Laboratory

P.0. Box 79

West Mifflin, PA 15122

E. Hillner

Westinghouse Electric Corporation

Bettis Atomic Power Laboratory

P.0. Box 79

West Mifflin, PA 15122

J. A. Redfield

Westinghouse Electric Corporation

Bettis Atomic Power Laboratory

P.0. Box 79

West Mifflin, PA 15122

Westinghouse Electric Corporation Bettis Atomic Power Laboratory

ATTN: G. G. Wedde 11

P.0. Box 79

West Mifflin, PA 15122

ONSITE

6 DOE Richland Operations office

E. A. Bracken

P. A. Craig

H. E. Ransom

J. J. Schreiber

0 . J. Elgert

Technical Information Offices

12 Rockwell Hanford Operations

H. Babad

L. C. Brown

R. A. Deju
No. of

Copies
R. J. Gimera
D. R. Gustavson
E. J. Kosiancic
C. W. Manry
I. E. Reep
J. H. Roecker
R. E. Smith
D. D. Wodrich
File Copy
Exxon

S. J. Beard

2 UNC/United Nuclear Industries

T. E. Dabrowsk $i$

File Copy

3 Westinghouse Hanford Company
A. G. Blasewitz
D. A. Cantley
R. E. Lerch

78 Pacific Northwest Laboratory

R. P. Allen

W. J. Bailey

N. E. Ballou

E. R. Bradley (5)

A. Brandstetter

R. L. Brodzinski

L. L. Burger

D. B. Cearlock

T. D. Chikalla

M. 0 . Clon inger

R. L. Dillon

P. G. Doctor

H. Drucker

C. E. Elderk in

J. R. Eliason

J. A. Franz

G. W. Gee

R. W. Goles

C. R. Hann

A. J. Haverfield/W. R. Wiley 
No. of

Copies

0. F. Hill

J. H. Jarrett

A. B. Johnson, Jr. (25)

R. S. Kemper

M. R. Kreiter

L. T. Lakey

J. M. Latkovich

R. C. Li ikala

R. P. Marshall

J. L. McElroy

C. L. Mohr

R. D. Nelson

J. M. Nielsen/R. W. Perk ins

R. E. Nightingale

D. E. Olesen

A. M. Platt

J. V. Robinson

C. M. Unruh

H. H. Van Tuy 1

R. E. Westerman

E. J. Whee lwright

M. K. White

L. D. Williams

Technical Information (5)

Publishing Coordination YO(2) 